\author{
NBER WORKING PAPER SERIES \\ ON \\ HISTORICAL FACTORS IN LONG RUN GROWTH
}

\title{
A BRIEF HISTORY OF EDUCATION \\ IN THE UNITED STATES
}

\author{
Claudia Goldin
}

Historical Paper 119

\author{
NATIONAL BUREAU OF ECONOMIC RESEARCH \\ 1050 Massachusetts Avenue \\ Cambridge, MA 02138 \\ August 1999
}

The data series compilation was funded by a grant from The Spencer Foundation through the NBER. I am grateful to the research assistants who ably helped with this project: Nora Gordon, Marina Jovanovic, and Michael Pisetsky. I thank Caroline Hoxby for consultation on some of the series and Tom Snyder of the U.S. Department of Education, National Center of Education Statistics for unstinting help with numerous details. The series that are not included with this essay can be obtained by request to cgoldin@ @harvard.edu Any opinions expressed are those of the authors and not those of the National Bureau of Economic Research.

(C) 1999 by Claudia Goldin. All rights reserved. Short sections of text, not to exceed two paragraphs, may 
be quoted without explicit permission provided that full credit, including (C notice, is given to the source. A Brief History of Education in the United States

Claudia Goldin

NBER Historical Paper No. 119

August 1999

JEL No. I2, N3

Development of the American Economy

\begin{abstract}
This essay is the companion piece to about 550 individual data series on education to be included in the updated Historical Statistics of the United States, Millennial Edition (Cambridge University Press 2000, forthcoming). The essay reviews the broad outlines of U.S. educational history from the nineteenth century to the present, including changes in enrollments, attendance, schools, teachers, and educational finance at the three main schooling levels -- elementary, secondary, and higher education. Data sources are discussed at length, as are issues of comparability across time and data reliability. Some of the data series are provided, as is a brief chronology of important U.S. educational legislation, judicial decisions, and historical time periods.
\end{abstract}

Claudia Goldin

Department of Economics

Harvard University

Cambridge, MA 02138

and NBER

cgoldin@harvard.edu 


\section{General and Comparative Aspects of Nineteenth and Twentieth Century U.S. Schooling}

The education and training of a population, in the United States and elsewhere, is a critical input to productivity and thus to economic growth. Education directly enhances productivity, and thus the incomes of those who receive schooling, by providing individuals with useful skills. Schooling also spurs invention and innovation, and enables the more rapid diffusion of technological advances. The role of education changes with technological progress; some technologies have placed heavy demands on the cognitive skills of workers, whereas others enabled the substitution of machinery for individual skill. Formal education, especially basic literacy, is essential for a well-functioning democracy, and enhances citizenship and community. Religious beliefs have also been important in fostering both public and private education even in the United States with its long history of separation of church and state. Schooling is also a pure consumption good, enabling people to better understand and enjoy their surroundings. Education can, thus, serve a multitude of functions in the economy, polity, community, and religious and personal lives of a people.

It is, perhaps, no wonder that education diffused rapidly among the free residents of the world's greatest nineteenth century democracy. By the 1840s, according to some estimates, primary school enrollment per capita in the United States had exceeded that in Germany, and by this standard Americans had become the best-educated people among those in the world's richer nations (Easterlin 1981). U.S. literacy rates were also extremely high, once again among the free population. America borrowed many educational concepts and institutions from Europe but tailored them in particularly American ways. U.S. schools, at almost all levels, were more practical and applied than those in Europe, yet they were not industrial and were rarely vocational. They became, early on, free and publicly funded and were generally forgiving in allowing youths to enter each level independent of age, social status, previous school record, and sex. After the establishment of publicly funded primary schools, girls were educated for about the same number of years as were boys, and during the early to mid-twentieth century, a greater fraction of girls than boys attended and graduated from secondary schools $(<$ CG.A.11 $\rangle){ }^{1}$

Although it would be useful to present school enrollment, attendance, and literacy rates for the early to mid-nineteenth century, they are still fragmentary and subject to many potential biases. They were not included in the previous edition of Historical Statistics of the United States, and although there has been considerable research on the subject in the past twenty-five years, the data remain imperfect. Part of the problem is the incompleteness of the data geographically (see, e.g., Fishlow 1966). Massachusetts and New York, for example, have been studied in great depth for 1790 to 1850 (see, e.g., Kaestle and Vinovskis 1980). But even in those states, enrollment rates that have been estimated for youths 5 to 19 years old are too high be to consistent with independent evidence on the occupations of youths. Perhaps some youths enrolled in school but did not attend, or perhaps school districts inflated enrollments. Even though precise estimates are beyond the task here, there is no widespread disagreement among scholars that by the middle of the nineteenth century U.S. schooling rates were exceptionally high, schooling was widespread among the free population, and literacy was virtually universal, again among the free population (for illiteracy rates since 1870, see <CG.C.2〉).

\footnotetext{
${ }^{1}$ Text in <-> refers to the series I have compiled for the new edition of Historical Statistics. Only those that are bolded are included with this essay. See Table of Contents at the end of the essay for a complete listing of the education data series to be included in the new Historical Statistics.
} 
How the new nation of the United States managed in the short span of a half-century to attain the status of the best-educated country in the world is a rather involved tale. Until the midnineteenth century most elementary education was offered in "common schools" that were publicly operated but often not completely publicly funded. In some districts, parents received a "rate bill" for their children's education. Elsewhere, part of the term was publicly funded and the rate bill supported an extended term. In large cities, such as New York City, there were, early on, pauper schools paid for by public funds and private schools for the more fortunate. The details are complicated by the highly local nature of education in the United States. What is perfectly clear, however, is that virtually every state in the nation shifted to publicly funded education at the elementary or common school level in the decades following the American Civil War.

The claim that Americans became the best-educated people in the world by the midnineteenth century may, however, be somewhat overstated. Some European countries had, until the beginning of the twentieth century, far better institutions of higher education than did the United States. But European educational systems were, with few exceptions, elitist well into the twentieth century. Both secondary and higher education was reserved for those with exceptional abilities, stemming from both family background and innate differences. The U.S. system of education, in contrast, was almost at its start distinctly egalitarian. Americans eschewed different systems for different children, and embraced the notion that everyone should receive a "common," unified, academic education. There were gaping holes in the system, of course. Slaves received virtually no formal instruction, especially after southern states passed laws that prohibited the teaching of slaves to read (the first was passed in 1830). Free blacks, even in the North, were in segregated schools, and southern schools remained de jure segregated even after the famous Brown v. Board of Education (1954) case judged such laws to be unconstitutional. And there is also the difficult issue of de facto segregation by race, immigrant status, and income.

The substantial levels of schooling and literacy in the nineteenth century United States were achieved within a highly decentralized educational system. The federal government today still accounts for a small fraction (7 percent) of primary and secondary educational expenditures, and even the states do not provide the majority of school revenues (<CG.D.1〉). School finance and curriculum decisions are the domain of school districts, and the origin of these districts is yet another detail from the earliest years of the Republic's educational history.

As the new nation expanded, the township model of school organization, begun in New England, was adopted by many states. But most new states were too rural for township schools, and, instead, created even smaller jurisdictions. School districts, first counted by the Office of Education in the early 1930s, numbered then about 128,000 (<CG.A.1.1>). Some were not fiscally independent, in the sense of setting their own tax rates, but, rather, had tax rates set by larger governing units, such as counties or townships. But many were fiscally independent. Thus, even by the third decade of the twentieth century, the United States had an enormous number of school districts with independent decision-making powers. America's large cities 
had, by that time, already experienced major school district consolidation and virtually all cities with populations exceeding 20,000 people had been consolidated into one school district by the early 1900s. Consolidation of rural districts occurred slowly until the 1950s. The central point is that most of the decisions regarding elementary and secondary education in America occurred at relatively disaggregated levels — cities, towns, and rural communities.

The large number of school districts across the United States, the vast majority of which were fiscally independent, means that decisions concerning resources devoted to schools, teachers, education generally, and curriculum were made locally. In many European countries, such decisions were made at a much higher level, often nationally. It is possible that the more disaggregated level of educational decision-making fostered education for the masses, particularly during the nineteenth and the early-twentieth centuries. Even though some districts were considerably poorer than others, the greater homogeneity within the districts could have greatly enhanced school expenditures. The reasoning is simple. Education, particularly at the secondary level, was primarily a "private good" that was publicly provided. Families could always opt out of the public system, although pay taxes to it, and send their children to private school. The greater the homogeneity within the community concerning "tastes" for education, the more citizens will vote to spend on education. If the decision-making unit includes families with widely differing incomes and tastes for education, it is possible that both the bottom and the top of the distribution will opt out of the public education system, leaving the middle group with a poorly financed or non-existent school system. Thus, greater local governance could account for the more rapid and more complete spread of secondary schooling in the United States than in Europe in the early to mid-twentieth century.

The greater level of education in the United States than Europe until late in the twentieth century is, of course, due to a host of factors and not just the decentralization of educational decision-making. These other factors include higher levels of wealth, lower relative opportunity cost for youths, competing religions that valued the ability of the laity to read the bible, and the ideology of democratic ideals of universal literacy (Goldin and Katz, 1997, 1999).

\section{Educational Institutions and Education Data}

The large number of school districts and the highly localized nature of school finance and administration in the United States complicate the compilation of education data for the United States. Rather than being collected by one national agency or even many state agencies, most of the series are built up first at the state level from the localities and then at the federal level from surveys of the states. The procedure differs from series to series, although most come from the states through the federal government. The federal government began to collect data on education from the states just after the establishment of the Office of Education in 1867.

The Office of Education has had a rather complicated history but is of sufficient importance to the data series that it shall be told in brief. The Bureau of Education, the forerunner of today's Department of Education, was established in 1867 and became the Office 
of Education in 1869, an agency of the Department of the Interior where it stayed for 70 years. It was known as the Bureau of Education for those 70 years, but in 1929 it was renamed the Office of Education. In 1939 it became part of the Federal Security Agency and was, in 1953, included in the new agency of Health, Education, and Welfare (HEW). The Department of Education became a separate cabinet-level agency in 1980. Each of the states also eventually appointed a superintendent or commissioner of education and founded an office, bureau, or board of education. The first state board of education was established in Massachusetts in 1837 and was headed by Horace Mann, an individual best known for his tireless crusade for free common schools.

Most of the data in the series begin with the establishment of the federal Bureau (or Office or Department) of Education. Thus the earliest date for education series is around 1870 (e.g., <CG.A.2>). As noted before, this is especially unfortunate with regard to the history of the common and elementary schools. The data for secondary school education suffer less from this omission since the expansion of high schools began in the late nineteenth century. Private academies, functioning much like secondary schools, proliferated in the mid-nineteenth century but no hard data can be found on their numbers and impact. Institutions of higher education in the United States date back to the opening of Harvard University in 1638. But at the aggregate level they, too, can be examined quantitatively only after 1870. As with secondary schools, there is little lost since only a small fraction of Americans could have been attending colleges and universities before.

Despite various problems in assembling the education data series, the relative stability and uniformity of U.S. educational institutions has simplified the task. The levels of education in the United States have not varied much across time and space. "Common school" generally includes youths between ages 6 or 7 and 14 or 15 (or older, if the youth had not attended regularly). That is, common school generally means grades 1 to 8 , even though the schools were "ungraded," occupied a single room, and had but one teacher. Common schools were mainly found in the "open country" or rural areas, and continued to be numerous until the mid-twentieth century (<CG.A.1.6>). Youths in rural areas often went to common school for longer than eight years, but this was generally remedial. Only rarely did it mean they were being taught at the secondary school level (see, e.g., Goldin and Katz 1999b). Towns, villages, and cities had graded elementary schools.

Secondary or high school generally means grades 9 to 12 , or ages 14 or 15 to 17 or 18 . At the start of the "high school movement" in the early 1900s, however, many high schools in small towns covered only grades 9 to 10 or 11 . Several curriculum changes have altered the two levels, elementary and high, across the twentieth century. The "junior high school" was introduced in 1909 (in both Columbus, OH and Berkeley, CA) and spread rapidly to other districts. It was adopted to keep pupils, who would otherwise leave at age 14, to grade 9, award them a diploma, and give them practical training, for example in shop and home economics. Since junior highs included grades 7 to 9 , elementary school was shortened to grades 1 to 6 , and high schools became "senior highs," covering from grades 9 to 12. This system is known as "63-3," and the previous one as "8-4." At various points in the past century, some districts returned 
to the previous model whereas others eliminated the junior high school and introduced the middle school, encompassing grades 5 to 8. Curriculum changes are far more difficult to track, as will be discussed in the section on secondary schooling.

Most of the series presented employ the school, rather than the calendar, year. That on primary and secondary school enrollment, however, switches in 1965 to "opening fall" enrollment (<CG.A.3>) and that for higher education switches in 1946 (<CG.B.2〉). The distinction concerns the period within which enrollments are accumulated. "Opening fall" enrollment is believed to be the more accurate method and counts only those students enrolled at the beginning of the school year, whereas the other method accumulates enrollments during the entire year. The difference is trivial for elementary and secondary school students. For college and university enrollments, however, there could be more substantial differences if students transfer from one institution to another.

Each state, today and in the past, determines what constitutes promotion and graduation. With the establishment of the state universities, graduation from high school often implied automatic college admission. Thus states took great interest in the level of proficiency required to graduate from high school. Similarly, promotion from eighth grade in many states meant admission to public high schools and many states also took an interest in that transition. In the early twentieth century, particularly after World War I, various states pioneered in the testing of students. A version of the well-known Iowa Test of Educational Development began in the 1920s, but was not administered statewide for another decade. The New York and California Regents also produced their own exams. Only scant evidence, however, exists on time trends regarding elementary and secondary school exam scores (Bishop 1989). One aspect of the history of promotion and graduation is clear. There was considerable age-in-grade retention until the mid-twentieth century when automatic promotion became a more common phenomenon. Retention rates can be computed using $<$ CG.A.3> on the fraction of pupils continuing from grade 5. Because these data are for public school students only, the transit of private students (generally Catholic) to public schools after grade 8 complicates the calculation.

Higher education, at least since the mid-nineteenth century, has been a four-year program, although there are various exceptions and some important changes. One exception is that until the twentieth century, many professional degrees (e.g., law, medicine) did not require a baccalaureate degree and thus the first professional degree often included a B.A. Because of this feature, the series on undergraduate enrollment and degrees includes first professional degrees until the mid-twentieth century. Junior (or community) colleges have been two-year institutions ever since the beginning of the twentieth century. Normal (or teacher-training) schools were often two-year programs but became four-year in some states starting in the 1920s and in most others in the 1940s and 1950s. Teacher-training institutions complicate the higher education data to a considerable degree since the number of women enrolled in them was substantial and program length was not always specified. For that reason, some researchers exclude them in the older data but include them after the 1940s (e.g., Goldin and Katz 1999a). 
Schools at all levels can be under public or private control. At the elementary and secondary levels, the type of control is generally unambiguous in the data series. This is especially true with regard to denominational institutions. The vast majority of private kindergarten to twelfth grade (K-12) schools are denominational. (It is likely that control will be a more ambiguous concept in the future if school vouchers can be used in denominational schools, as they have been in a recent policy experiment involving Catholic schools.) Control of higher education has been a somewhat less transparent concept. In the first place, some institutions of higher education that were under private control received the initial Morrill Land Grant (1862) funds from the state (e.g., Cornell University, M.I.T., Yale, Rutgers). More important, the federal government supports research at private institutions and allocates student aid on the basis of need, not the control of the institution. All the G.I. Bills, for example, paid private and public tuitions, and Pell Grants subsidize students at a range of institutions. Thus, the control of the institution is not necessarily coterminous with the source of funding. It never was. Harvard University, for example, received funds from the Massachusetts colonial government and afterwards from the state until the early nineteenth century.

This essay ends with an extensive "note on the sources," but there are some details that must be addressed before. As already mentioned, most of the sources are the "administrative records" of localities and states. That is why the existence of the U.S. Bureau of Education, which compiled these data, is important to the construction of the series and why the earliest date for the series is about 1870. These administrative sources provide "flow" data, rather than "stock" data. That is, they give contemporaneous information on students, teachers, schools, finances, and so on, rather than the number of years of schooling of the population or the number of individuals who ever taught, to provide two examples. They reveal little about student characteristics in terms of age, sex, race, ethnicity, and family background, although some are occasionally indicated. Racial segregation of public schools in the South, for example, allows the calculation of high school graduation by race after 1930 (<CG.A.17>). Some administrative data are given by sex (e.g., <CG.A.11>). Because the administrative data are rarely given by age, the contemporaneous "flow" numbers have to be divided by the relevant population group to obtain rates.

Other potential sources of education data are the U.S. census, or Current Population Survey (CPS), or state censuses. The U.S. census, ever since 1850, has asked whether an individual had attended (almost any kind of) school (for at least one day) during the preceding year. But it was not until 1940 that the U.S. census, and later the CPS, asked the "stock" of education, that is the accumulated years of school or "highest grade completed" of the population. Only two states (Iowa and South Dakota) asked questions on educational attainment before 1940, and research on the subject has been done using the Iowa State Census of 1915 (Goldin and Katz 1999b).

The relationship between education and income, at the individual level, can be presented for the entire United States only beginning with 1940 (<CG.F.1〉 and 〈CG.F.2〉). But even the 1940 data are subject to considerable bias. Although the 1940 federal population census was the 
first to inquire of income and education, both variables contains omissions and biases. Wage and salary income was requested in 1940, but that from self-employment was first asked in 1950.

The education and income series (<CG.F.1> and <CG.F.2>) use comparable income measures for the decennial census years 1940, 1950, and 1960 (wage and salary income) and then switch, by necessity, to a more inclusive measure of income when using the Current Population Survey. Caution should be exercised in using these data to make inferences about the role of education in enhancing income. One reason is that the aggregate population is used (males greater than or equal to 25 years old) and there were large compositional changes between census years. From 1940 to 1950, for example, the fraction of young men with high school diplomas increased substantially. Because these persons had little job market experience, their average earnings were lower than those of older high school graduates and not much higher than those of older individuals without a high school diploma. The compositional change means that, in times of rapid educational advance, the role of more education (here a high school diploma) will not be as apparent than had the series been divided by age.

"Highest grade completed" was asked in 1940, but many older Americans had not attended graded schools and some went to school for more years than grades. There is considerable evidence that the 1940 census overstates the high school graduation rate of older Americans to a considerable degree (Goldin 1998). The graduation data are often inconsistent with those from administrative data, although those for lower grades are not. Educational data from the census (and also those from the Current Population Surveys) are also important because they allow tabulation of education by individual and family characteristics (e.g., $<$ CG.A.4>).

Even though the U.S. population census asked whether an individual had attended school during the previous year, the answers overstate the number of youths who were actually attending formal day school for at least several months during the year (they are, however, given for 5 to 19 year olds in <CG.A.15> and graphed in Figure 1). The length of time attended, as previously noted, was "for at least one day" and the type of school was virtually any, including night and commercial schools. Thus, for most of the period under consideration, the administrative data must be relied on for virtually all the series. It should be noted that the terms enrollment and attendance are used interchangeably in this series. Although the census question concerned attendance of school for at least one day, the convention is to use the term enrollment in this case.

Schools took various forms over the period in question. The common school was a simple one-room structure, often situated on someone's quarter section or farm. The town school in almost any era would be recognizable to those reading this essay, although there would be various differences across time. One is that elementary and high schools, early on, were often in the same building. Thus, it is impossible to produce separate series on these schools until the 1930s (<CG.A.1>). Some states listed virtually all elementary schools as high schools, whereas others had state laws requiring secondary schools to be separate structures. Similar ambiguities plague issues regarding instructional staff. States each had regulations concerning who could 
teach and what the prerequisites were. But these varied enormously across space and time. The series presented here accept the definitions in the administrative records. Someone who taught secondary school students was a secondary school teacher. But there are times, when even this distinction is opaque.

One last important data issue must be mentioned. Education is "life-long learning," and much of it does not take place in formal settings and is, thus, difficult to track. The series presented here will, by necessity, omit on-the-job training and also proprietary training institutions. It is possible to study the latter for much of the twentieth century because the Office of Education often collected information on them. Commercial schools proliferated in the 1910s and $1920 \mathrm{~s}$, but there is, at present, no readily available, comprehensive, and reliable series on them.

\section{The Three Transformations of American Education}

Schooling is intrinsically a hierarchical process both in terms of how one is taught and how teachers are trained. Thus any state or nation that has elementary schools must have teachers with knowledge exceeding that of the highest grade being taught in them. The teachers, in turn, would have to have been trained by someone with even greater knowledge. Thus, although the United States underwent three transformations of education (primary, secondary, and tertiary), all three levels were in place simultaneously for all of U.S. history. Europe, to be sure, was relied on in the nineteenth and early twentieth centuries particularly at the level of higher education. America imported instructional staff for colleges and universities and also exported students (many of whom returned as trained academics). But the fact that many American institutions of higher learning were founded far in advance of the third transformation is an indication of the importance of the highest levels of education for training at the most elementary.

The periodization of the three transformations dates the completion of each schooling level by the majority of youth. The completion of each of the transformations can be thought of as the moment when an education level was available and taken up by the "masses" or, put another way, when "mass education" reached that level. The first transformation brought the bulk of youth through common or elementary school (eighth grade) and occurred during the nineteenth century. The second transformation brought the majority of youth through secondary or high school and occurred in the first half of the twentieth century. The third transformation, still on-going, is bringing the majority of young adults through four-year higher education.

\section{A. Primary or Common School and Elementary Education}

The first educational transformation occurred over an extended period but moved rapidly during the middle of nineteenth century when fully free, publicly funded common schools diffused throughout the nation. Although compulsory education laws were also passed during the period of the common school transformation, it is believed that they lagged rather than led it. That is, the state laws were passed only after the majority of youths had already gone beyond the 
age of compulsion in the laws. As noted previously, the most interesting period of common school diffusion predates the era of readily accessible data.

Almost all of the data series concerning K-12 education begin with 1870. The exception is that for school attendance (for 5 to 19 year olds) from the U.S. federal population census (<CG.A.15>, see also Figure 1). Beginning with the collection of the administrative information by the Office of Education in 1870, data exist on public and private enrollments by level or grade (<CG.A.2 >), where common school students are classified in the K-8 group. More detailed data on students by grade can be computed after 1910 for public school students $(<$ CG.A.3 $\rangle)$. But it is not until the late 1910s, with the publication of the Biennial Survey of Education in the United States (see A Note on the Data Sources and Data Issues) that data are available to calculate student-teacher ratios (e.g., <CG.A.2.5>). Because the age of students was not collected in most administrative data, rates of attendance have to be computed by assuming an age group (e.g., 14 to 17 for secondary school) and using the data on population by age (and sex and race) contained in another chapter of Historical Statistics.

According to the data in <CG.A.2 > and <CG.A.15>, the transformation to "mass" primary school education (among the free population) was completed by the mid-nineteenth century. The transition, moreover, was similar for males and females (see Figure 2). Although none of these series reveals the precise fraction of males and females at different ages attending school, considerable work by educational historians has shown that, at least in the elementary and secondary grades, females attended school for more months than did males for much of the period. Even though a large fraction of youths were enrolled in and attending school, the attendance of those enrolled was between 60 to 70 percent of the school year from the 1850s to the 1910s or between 80 and 110 days per year (<CG.A.6.3>). All the data, as previously reported, regrettably say nothing about the pre- 1850 period.

Among the more important changes in elementary public school education since 1970 has been the increase in the fraction of public school youths in "special education programs" $(<$ CG.A.5 $\rangle$ ), the unionization of teachers ( $\langle$ CG.A.16 $\rangle$ ), the decrease in classroom size (<CG.A.2 $>$ ), and the increase in real expenditures per child (<CG.D.2 >). The increase in real expenditures per child should not be too surprising since the real cost of teachers, (nominal amounts are given in <CG.A.7> which must be deflated by a price index series in Historical Statistics), rises with general levels of productivity. But simple decompositions show that the increase in expenditures per pupil cannot be fully explained by the increase in the real wage of teachers, the decrease in classroom size, and the increase in more costly special education students. Administrative costs per pupil, it appears, have enormously increased. Another important recent change is the increase in pre-school education (<CG.A.14〉).

Most education data measure the quantity of schooling received, in years or grades. The quality of education is an equally important, yet less transparent, aspect. Quality can be proxied by the student-teacher ratio (<CG.A.2 $>$ ) or the length of the term (<CG.A.6.2 $>$ ), to mention two measures that can be used over the long run. Current concern with K-12 educational quality has focused on another measure, that of test-scores. Among the most widely used is the National 
Assessment of Educational Progress or NAEP (<CG.A.13>). Although the United States has done poorly in international test comparisons, NAEP scores have generally risen since the 1970s. A reconciliation of these two observations is yet to be accomplished.

\section{B. Secondary or High School}

The second transformation of American education was the "high school movement" and it was the most rapid of the three. In 1910 less than 10 percent of all U.S. youths graduated high school, but by 1940 the median youth was a high school graduate (<CG.A.11 $\rangle)$. And in certain parts of the nation (e.g., the Pacific, West North Central, and New England states), the "high school movement" was even more rapid (see <CG.A.17> and Figure 3). In those states, graduation and enrollment rates were as high in the 1930s as they would be until the 1960s (<CG.A.17> and <CG.A.18>). Because the "high school movement" began in the early part of the twentieth century and secondary school attendance was relatively meager before, little is lost from the late starting date for the series. (On the "high school movement" see Goldin 1998.)

The secondary school graduation rates in Figure 3 (and $\langle$ CG.A.17>) are computed by dividing the administrative data on high school graduates by the number of 17 year olds in the census division (aggregated up from the states). The secondary school enrollment rates are similarly computed, but the denominator is the number of 14 to 17 year olds. The fact that some students were older than 17 or younger than 14 may trivially affect the calculation. More important is that the state population data are available only for decennial census years and must be interpolated between them.

It may appear odd that the contemporaneous high school graduation rate, graphed in Figure 3, is higher in 1970 than it is after. Those data, it will be recalled, were obtained from administrative sources. Data from the major household survey of population - the Current Population Survey - show, to the contrary, that the fraction of 25 to 29 year olds, for example, claiming to have graduated from high school does not decline from 1975 to 1985 (corresponding to the approximate year of high school graduation of 1966 and 1976). Rather the fraction graduating high school increases and attains a level that is about 7 percentage points higher than in the administrative records for the same birth cohorts. That is, the contemporaneous public and private high school graduation rate in 1985 is about 73 percent (see Figure 3), but is 86 percent for the same cohorts in the household survey. Most of the difference in the two numbers is accounted for by the General Education Development (GED) credential (discussed below). The administrative records on high school graduation capture only those who receive diplomas from regular secondary schools, whereas the GED is an examination that can be passed later in life by those who dropped out of high school.

The series in <CG.A.17> and <CG.A.18> include public and private secondary school students. Also included are college preparatory students in institutions of higher education. Before high schools spread across the nation, many public and private universities and colleges had their own preparatory programs. Youths often entered these programs straight from elementary school or after several years at their local high school. The fraction of secondary 
school graduates coming from all private programs, including an estimate of those from the preparatory departments of colleges and universities regardless of control, is given in $<$ CG.A.19>.

Secondary schooling spread rapidly in the early twentieth century because schools were built and students in districts already having high schools were enticed to enter and remain. The increased demand for white-collar workers and for trained blue-collar workers spurred an interest in and demand for schooling beyond eighth grade. But secondary schools in the nineteenth century were institutions that generally trained youths to attend university. They often prepped pupils to pass the entrance examination of the local private college or the state university, if it had one. High schools were reinvented beginning in the late nineteenth century to be places of practical and applied learning. They also, of course, retained courses of study to train youth to enter institutions of higher education.

Curriculum is difficult to track because of changes in subject matter, among other details. The Office or Department of Education requested information from secondary schools from 1889-90 to 1981-82 on the number of pupils taking various subjects. These data are measured in "pupil-courses" and are expressed in <CG.A.9> as the percentage of pupils taking a course. A course that occupied one hour per week is, by necessity, given equal weight to one that occupied five hours per week. Thus the total can exceed 400 percentage points, even if each student took an average of four full-time courses. The data were systematized in several ways beginning in 1982. Courses were measured in "Carnegie units," where each Carnegie unit is a one-year course, generally equal to five 45 -minute periods per week for the entire year ( $\langle$ CG.A.10 $\rangle$ ). The course of study for the entire high school program (at graduation) is given in $\langle$ CG.A.10 $\rangle$, rather than an average for those currently in school (as often the case in <CG.A.9>). Whatever the defects of the historical data, they clearly show that the secondary school curriculum became more practically based and also broader in academic subject matter sometime in the 1920s.

As in the first transformation of American education, one may wonder what the effects of state legislation were in the "high school movement." All states passed compulsory education laws at some point in their history and most were accompanied by related legislation regarding child labor. The laws are complex and, prior to the late 1920s, the maximum age of compulsion was generally not binding. Rather, youths could be excused if they obtained a labor permit and had attained some minimum level of schooling. Although the jury is still out, there is considerable evidence that compulsory education laws did not "cause" much of the high school movement. States did, however, pass other legislation that aided secondary school expansion. One neglected piece of legislation is the "free tuition law." Because school districts were small and numerous in rural areas, some districts would have had high schools while others would not have. Families would be responsible to pay tuition to the district with the high school if they lived in a district without one but sent their child to the school. The "free tuition laws" made the sending district responsible for the payment of tuition. Most of these laws were passed in the 1910s and 1920s; Nebraska, for example, passed a "free tuition law" in 1907 and Iowa did in 1913. 
A more recent development in secondary schooling is the General Educational Development (GED) credential. The GED was instituted during World War II (in 1942) to give veterans without a high school diploma a chance to earn credit for their informal education outside school. Civilians were allowed to take the examination in 1952. The data on individuals taking (and passing) the exam exist from 1971 and are given in <CG.A.12>.

At the start of this essay, it was noted that, by most accounts, the United States exceeded all other nations in mass elementary school education by the 1840s. It not only retained that lead, but with the "high school movement," it increased it substantially (Goldin and Katz 1997). Although Germany instituted various types of secondary schools in the early twentieth century, neither it nor any other European country was able to put their "masses" through non-vocational full-time secondary school until well after World War II. Thus, when the United States passed the G.I. Bill of Rights (1944), it could promise to put returning veterans through college because the median eighteen year old was already a high school graduate. No other country could accomplish the same task nor would for some time after.

\section{Tertiary or Higher Education}

The third great transformation of American education — that to mass higher education has been the most prolonged and is still ongoing. Part of the reason for the length of the transition, as noted previously, is that lower levels of education need higher ones to train teachers. All nations require institutions of higher education long before they are to be transformed into nations of highly educated people. Institutions of higher education serve many purposes, of course. Early in American history, for example, these institutions trained ministers, as well as lawyers, and military and political leaders.

Institutions of higher education (B.A. granting, four-year) increased steadily in numbers in the United States across the nineteenth century. There was a large burst of activity in the 1870s in the public sector and in the 1890s in the private sector (Goldin and Katz 1999a, analyze institutions surviving to the 1930s). The increase in public universities in the 1870s owes to the celebrated Morrill Land Grant Act of 1862, one of many pieces of legislation passed during the Civil War's $37^{\text {th }}$ Congress that had been previously defeated or vetoed. The Morrill Land Grant Act gave scrip in the form of federal land to each of the states "for the endowment, support and maintenance of at least one college where the leading object shall be - without excluding other scientific and classical studies and including military tactics - to teach branches of learning as are related to agriculture and mechanic arts" (Nevins 1962). The institutions could be publicly controlled, or privately controlled, as they were in states such as New York and New Jersey.

The Morrill Land Grant Act did not, however, set up the first state universities. By 1862 the majority of existing states outside the northeast (19 out of 24) already had a state institution of higher education; some states (e.g., Virginia, Ohio) had more than one. States used their Morrill funds in various ways. Some established their first institution (e.g., Nebraska), some gave the money to the existing state institution (e.g., Wisconsin), and others established an additional university (e.g., Michigan). It should also be noted that the Morrill Land Grant Act of 
1862 was but the first of several related acts. An amendment to the original act extended the land grants to states as they entered the union. The second Morrill Act in 1890 set up annual appropriations to the land-grant institutions, and was indirectly responsible for establishing those now termed the "historically-black" institutions of higher education by denying funds to states that did not provide facilities to black students (<CG.B.7〉).

The series in $<$ CG.B.1 $>$ on the number of institutions of higher education contain several complicated features. One concerns teacher-training institutions, also known as normal schools and teachers' colleges. Teachers' colleges often began as 2-year institutions but later became 4year institutions, able to grant the baccalaureate degree. Many of the state teachers' colleges were later made into the second tier of the state university system (as, for example, in California and Illinois) or the state university system itself (as in New York State). Thus, in the absence of detailed knowledge of the type of degrees awarded in each year, it is impossible to separate the institutions into 2-year and 4-year. Another complication is that state universities often establish separate campuses across the state. Before 1975 these branch campuses were treated as part of the central university, whereas after 1975 they are treated as separate institutions (see demarcation in $\langle$ CG.B.1 >).

The series on the enrollment of individuals in institutions of higher education $(<$ CG.B.2 $\rangle)$ is more complicated than that for elementary and secondary schools. In the first place, many students in their first professional degree program were simultaneously in an undergraduate program, until the middle of the twentieth century. Undergraduates and first professional degree students are, therefore, combined for consistency in the historical series. The computed undergraduate enrollment rates (<CG.B.2.2〉) are therefore more inflated after the 1940s, when few professional students would not have had an undergraduate degree. Another difficulty is deciding what age group to use in the denominator. College students more widely disbursed by age than are those in K-12, and the inclusion of the professional and graduate students means that a wider age group is required. The standard is to use 18 to 24 year olds.

The main gender difference in education in U.S. history has been the greater enrollment of males in colleges and universities, particularly 4-year institutions. But ever since the early 1980s women have enrolled in institutions of higher education and received B.A. degrees in greater numbers than have men (see <CG.B.3> on degrees, and <CG.B.2> on enrollment). As can be seen in Figure 4, the fraction of 20 to 24 year olds enrolled in school is now greater for females than for males. It should also be noted in Figure 4 that the fraction of males enrolled in school has only recently exceeded the peak level of the late 1960s (the same is true for 20 to 24 year olds). This anomaly is mainly due to the war in Viet Nam and draft deferments.

The transition to mass higher education in the United States owes to several factors. One is the increase in high school graduation early in the twentieth century. Another is the G.I. Bill for World War II and Korean veterans. Recent research has shown that these G.I. Bills increased the level of undergraduate education above what would have been the case in their absence (Stanley 1999). Further, they were more than compensatory. A somewhat higher fraction of men went to college than had they not served in these wars. The spread of the Scholastic 
Aptitude Test (SAT) particularly in the 1940s also democratized the admissions procedure for college. Finally, the explosion of public junior colleges (also known as two-year or community colleges, see $<$ CG.B.1 $>$ ) in the 1970s allowed even the financially and scholastically constrained individual to continue in higher education.

\section{Interpretation}

This essay has emphasized the leadership of the United States in education - the rapid increase in schooling in the early nineteenth century, the widening lead in the early to midtwentieth century, and the high levels of tertiary education in the post-World War II period. By the very end of the twentieth century, however, many of the world's rich nations, and even some of the "newly industrialized economies," are closing the gap with the United States in educational quantities. More important, they are rapidly exceeding the United States with respect to educational quality, and even with respect to quantities adjusted by quality, although this concept is difficult to measure.

Many of the virtues of the U.S. educational system, that served Americans so well in the past, are fast becoming disadvantages and drawbacks. The extremely open and forgiving system that enabled generations of Americans to continue to secondary school and college now means that there are no rigid standards and no national examinations. The upper half may be doing well, but the bottom half is often left behind in the United States. In many European countries, the bottom half is challenged and sorted by standardized tests or offered technical tracks. The localized nature of educational finance in the United States may have advanced schooling in previous decades. But it is, more and more, coming under attack for its inherent inequities. Rich districts can afford good schools but poor districts cannot. School finance equalization attempts to reallocate funds within states. But it often has deleterious and unintended consequences leaving the poor no better off than before and occasionally worse off.

Describing educational change in American history is a much easier task than understanding why change occurred and what its consequences have been. With regard to advances in schooling, it is clear that there is a complicated interrelationship between the demand for educated workers and citizens, and the public's response. Legislation, as pointed out throughout this essay, has been important at various critical junctures in U.S. history, was not the driving force behind "mass education." The public provision and funding of education, however, have been strong positive forces in spurring the three great transformations of American education.

There are many studies (e.g., Goldin and Katz 1999b) demonstrating positive relationships between education and income and between schooling and productivity. Many countrywide studies also reveal strong relationships between education and income and between schooling and economic growth. Several potential biases plague these fine research efforts. Though we still do not know for certain, it would appear that the extraordinary record of economic growth, income, and productivity throughout U.S. history owes something to its lead in education for the masses. 


\section{A Note on the Data Sources and Data Issues}

The majority of the series are updated versions of those in Historical Statistics (U.S. Bureau of the Census 1975). Many, however, are new to the volume. Most, although not all, of the series are updated annually by the National Center for Education Statistics (NCES) of the U.S. Department of Education and are published in the Digest of Education Statistics. Tables from recent editions of the Digest of Education Statistics and other NCES publications can be accessed at http://nces.ed.gov/. In the process of updating, the NCES often revises previously published data and thus these series may in the future be altered in small ways by NCES. NCES also published 120 Years of American Education: A Statistical Portrait (U.S. Department of Education 1993) and its editor, Thomas Snyder of NCES, was enormously giving of his time during the preparation of the new Historical Statistics education series. The series presented here borrow from some of the tables in 120 Years, which are updated versions of the historical series in the Digest and many from Historical Statistics.

The primary sources for most of the series begin in 1869-70 with U.S. Office of Education, Annual Reports of the Commissioner of Education. These reports extend to 1916-17 when they were superseded by the Biennial Survey of Education in the United States. The Biennials, published for the even numbered school year from 1917-18 to 1957-58, include general information on the U.S. school systems, reports from the state school systems and those of the cities. The Biennials also include a wealth of data on all levels of education and types of school, including private and commercial.

Much of the detailed data in the early Biennials came from surveys of school districts, and complementary data came from surveys of the states. Sometime in the early 1930s, the Office of Education revised some of the earlier data to take account of obvious underreporting from the school districts. The Office never mentioned the procedure that was used nor commented that the revisions were being made. It simply published series with different numbers. (See Goldin 1994, 1998 for a discussion of the procedure that the Office must have used in the construction of the secondary school data.)

The Digest of Education Statistics, published since 1962, picks up where the Biennials leave off. Recent tables can be accessed through the NCES website. The sources for the Digest are surveys and estimates of the Department of Education and other agencies.

Private school data were often collected by the Office or Department of Education but, beginning in the 1950s, data from the National Catholic Welfare Conference have been relied on for the bulk of private students, those in Catholic schools (see, e.g., <CG.A.17>). The pioneering work of Abbott L. Ferriss (1969) in rendering consistent many of the historical education series should also be mentioned. 


\section{Bibliography}

Bishop, John H. 1989. "Is the Test Score Decline Responsible for the Productivity Growth Decline?" American Economic Review 79 (March): 178-97.

Easterlin, Richard A. 1981. "Why Isn't the Whole World Developed?" Journal of Economic History 41 (March): 1-17.

Ferriss, Abbott L. 1969. Indicators of Trends in American Education. New York: Russell Sage Foundation.

Fishlow, Albert. 1966. "The American Common School Revival: Fact or Fancy?" In Henry Rosovsky, ed., Industrialization in Two Systems: Essays in honor of Alexander Gerschenkron New York: Wiley.

Goldin, Claudia. 1994. "Appendix to How America Graduated from High School: An Exploratory Study, 1910 to 1960.” NBER Working Paper No. H57 (June).

Goldin, Claudia. 1998. "America's Graduation from High School: The Evolution and Spread of Secondary Schooling in the Twentieth Century," Journal of Economic History 58 (June): 34574.

Goldin, Claudia and Lawrence F. Katz. 1997. "Why the United States Led in Education: Lessons from Secondary School Expansion, 1910 to 1940.” NBER Working Paper No. 6144 (August).

Goldin, Claudia and Lawrence F. Katz. 1999. "Human Capital and Social Capital: The Rise of Secondary Schooling in America, 1910-1940," Journal of Interdisciplinary History 26 (Spring): 683-723.

Goldin, Claudia and Lawrence F. Katz. 1999a. "The Shaping of Higher Education: The Formative Years in the United States, 1890 to 1940," Journal of Economic Perspectives 13 (Winter): 37-62.

Goldin, Claudia, and Lawrence F. Katz. 1999b. "Education and Income in the Early $20^{\text {th }}$ Century: Evidence from the Prairies, 1915 to 1950." NBER Working Paper No. 7217 (July).

Kaestle, Carl F. and Maris A. Vinovskis. 1980. Education and Social Change in NineteenthCentury Massachusetts. New York: Cambridge University Press.

Nevins, Allan. 1962. The State Universities and Democracy. Urbana, IL: University of Illinois Press.

Stanley, Marcus. 1999. "College Education and the Mid-Century G.I. Bills." NBER Working Paper (forthcoming). Paper presented to the 1999 NBER Summer Institute. 
U.S. Bureau of the Census. 1975. Historical Statistics of the United States from Colonial Times to the Present. Washington, D.C.: U.S. GPO.

U.S. Department of Education, National Center for Education Statistics. 1993. 120 Years of American Education: A Statistical Portrait. Washington, D.C.: U.S. GPO. 
</ref_section> 


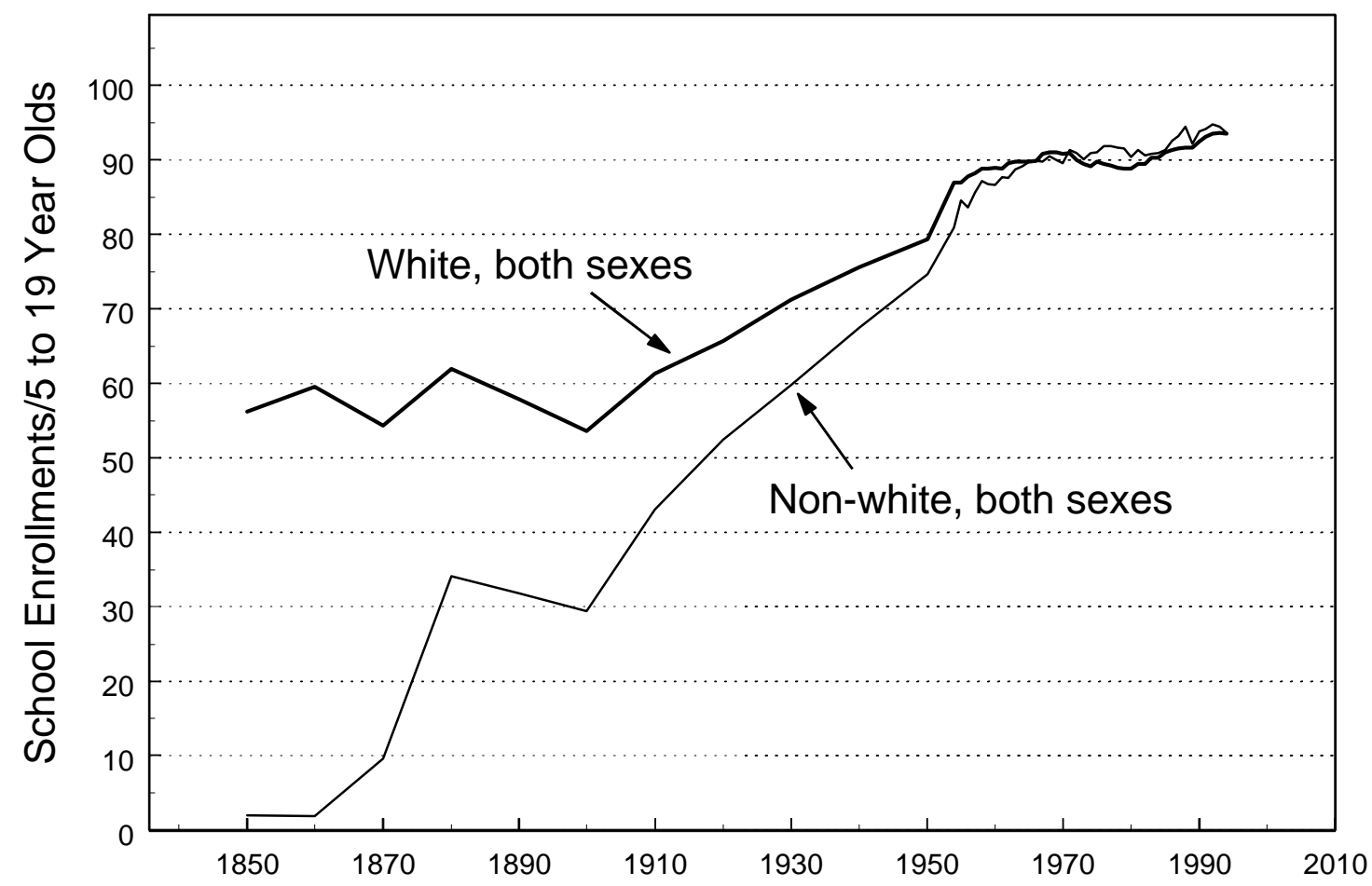

Figure 1: School Enrollments/(5 to 19 year olds) by Race for Both Sexes (expressed as a percentage), 1850 to 1994

Source: $\langle$ CG.A.15>. 


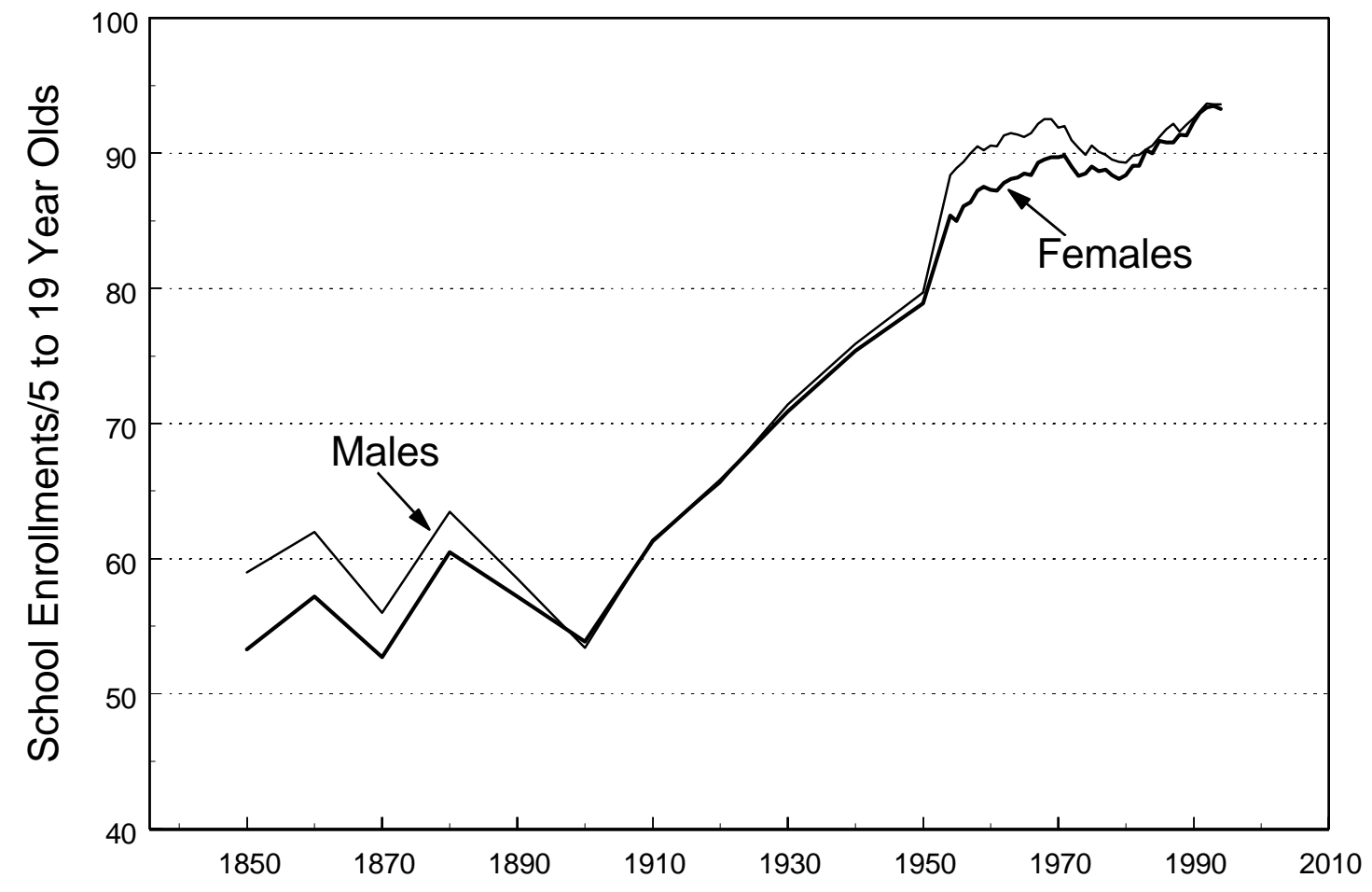

Figure 2: School Enrollments/(5 to 19 year olds) by Sex for Whites (expressed as a percentage), 1850 to 1994

Source: <CG.A.15>. 


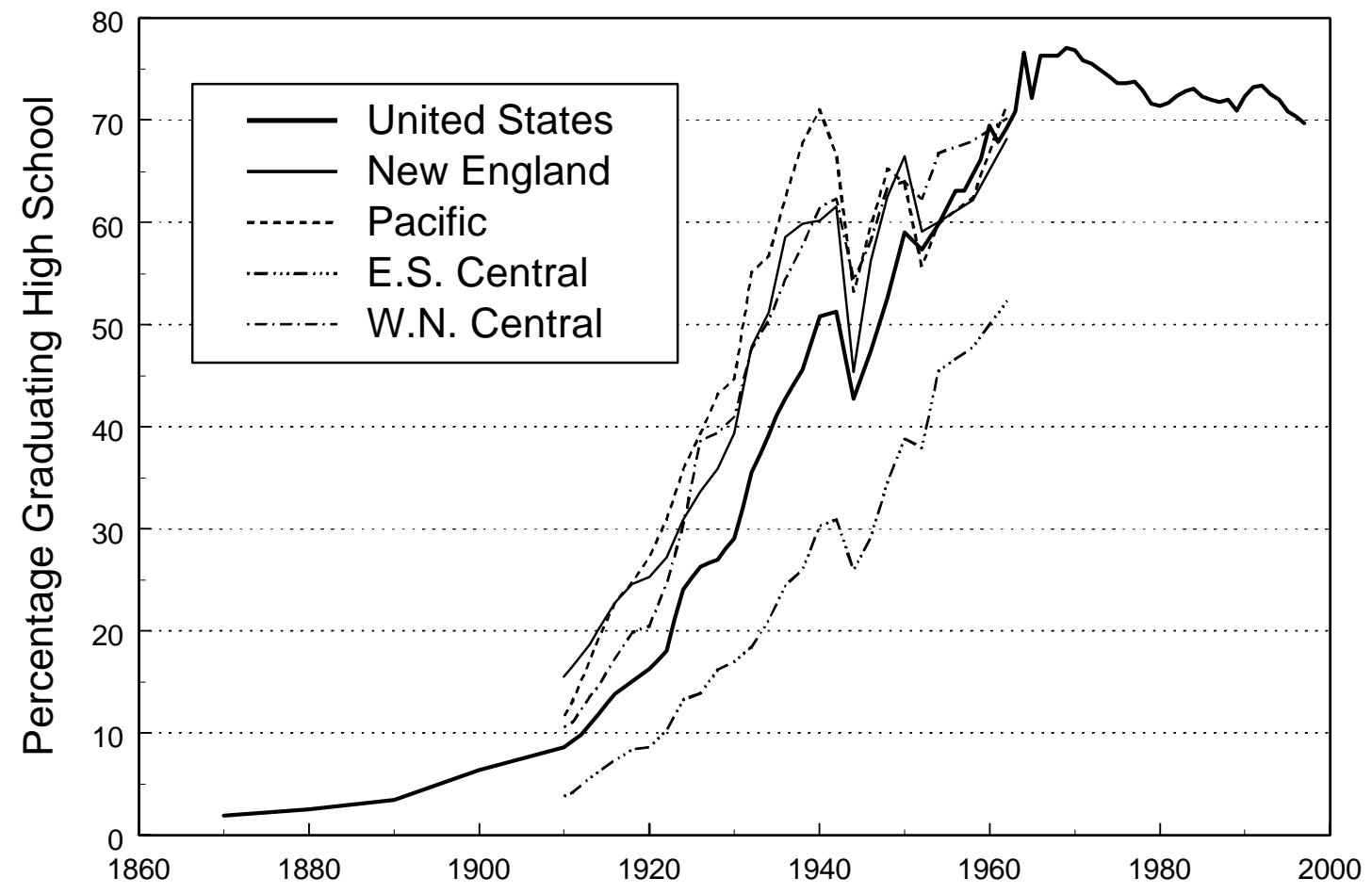

Figure 3: Public and Private High School Graduation Rates (percentage of 17 year olds) for the United States and Four Census Divisions

Sources: <CG.A.11 > and <CG.A.17>.

Note: The data on high school graduates come from administrative sources and do not include those who might later earn the GED credential. See text. 


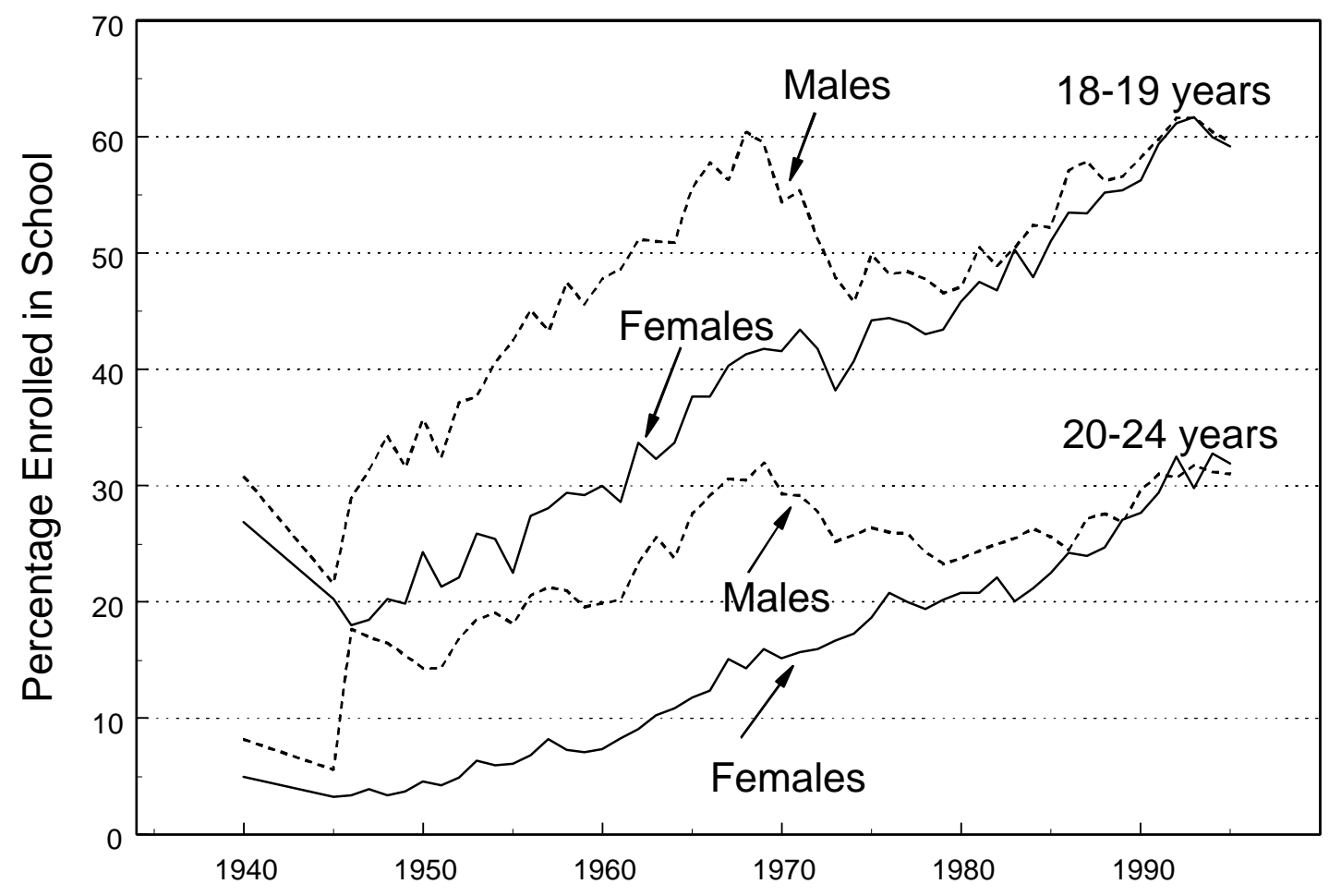

Figure 4: Enrollment by Sex for 18-19 year olds and 20-24 year olds Source: <CG.A.4>. 
Timeline of Important State and Federal Legislation, Judicial Decisions, and Historical Periods in U.S. Education

1635 Boston Latin School: first "grammar" or secondary school in the colonies opens; Boston Latin was funded, in part, by income from a public land sale, making it the first public school in America.

1638 Harvard University: the first university in America, founded in 1636, is opened to students.

1647 Old Deluder Satan Act of the General Court of the Colony of Massachusetts Bay: Towns of 50 families or more must established a public elementary school and towns of 100 families or more must establish a public "grammar" school "with a master capable of preparing young people for university level study."

1785 First state university: chartered in Georgia.

1785 Land Ordinance of 1785: "an Ordinance for ascertaining the mode of disposing of Lands in the Western Territory" (north of the Ohio River and east of the Mississippi) passed by the Continental Congress, reserved section 16 of each congressional township (36 squaremile sections) for the support of public schools within the township.

1787 Northwest Ordinance: "an Ordinance for the government of the Territory of the United States northwest of the River Ohio" passed by the Continental Congress, noted that because "religion, morality, and knowledge" are essential to good government, "schools and the means of education shall forever be encouraged."

1789 U.S. Constitution: Tenth Amendment provides legal basis for making education a state function. First Amendment and Fourteenth Amendment together assure separation of church and state in the provision of education at the local level.

$1789 \rightarrow$ State constitutions: provide for the establishment of statewide school systems and, for states entering the union after 1862, contain allotments of federal lands to support state institutions of higher education.

1819 Dartmouth College v. Woodward: charter of Dartmouth College was determined to be a contract and thus the state legislature of New Hampshire could not abrogate it and set up a state college instead.

1830 Laws prohibiting the teaching of slaves to read: first such law passed in Louisiana; Georgia and Virginia follow in 1831; Alabama in 1832, South Carolina in 1834, and North Carolina in 1835.

1833 Oberlin College: (was Oberlin Collegiate Institute) in Ohio is founded as the first coeducational college in the United States.

1837 Massachusetts Board of Education: Horace Mann appointed to head the first state board of education.

1850 Amendment to the Land Ordinance of 1785: increased educational allotment to two sections, 16 and 36, for states entering after 1850.

1852 Compulsory school-attendance act: Massachusetts passed the first such law in the United States.

1862 Morrill Land Grant Act: Congress granted funds (scrip in federal land) to states to found colleges of mechanical arts (engineering), military science, and agriculture.

1867 U.S. Office of Education: established 
1872 Kalamazoo Decision: Michigan Supreme Court decision validated use of local funds for secondary school education similar to their use for elementary (common) school education.

1887 Hatch Act: provided government support of state agricultural experiment stations, as joint research projects of state agricultural colleges and the U.S. Department of Agriculture.

1890 Second Morrill Land Grant Act: Congress instituted regular appropriations for the landgrant colleges; the "historically black" institutions were set up in response to the demands of this act that nonwhite students be provided facilities.

1896 Plessy v. Ferguson: Supreme Court validated the separation of black and white pupils and established the "separate but equal" doctrine.

1909 The Junior High School: first ones established in Columbus, OH and Berkeley, CA.

1914 Smith-Lever Agriculture Extension Act: set up agricultural extension.

1917 Smith-Hughes Vocational Act: gave funds to support agriculture, industry, and home economics education and created the Federal Board for Vocational Education.

1918 Compulsory school-attendance laws: all states have such a law, although the maximum age of compulsion often exceeds the age at which a work-permit can be granted.

1942 General Education Development (GED) Program: initiated to provide World War II veterans lacking a high school diploma with an opportunity to earn a secondary school credential; civilians were first able to take the test in 1952.

1943 West Virginia Board of Education v. Barnette: Supreme Court ruled that students who are Jehovah's Witnesses were not obliged to participate in saluting the flag.

1944 G.I. Bill of Rights: $78^{\text {th }}$ Congress provided subsistence allowances, tuition fees, and supplies for the education and training of veterans of World War II in a wide variety of settings including colleges, high schools, and vocational training institutions.

1950 National Science Foundation: established to "promote the progress of science; to advance the national health, prosperity, and welfare; to secure the national defense; and for other purposes."

1952 Korean War G.I. Bill of Rights: educational benefits of the 1944 Bill are extended to Korean War veterans and others who served in the armed forces during the war period.

1954 Cooperative Research Program: authorized the U.S. Commissioner of Education to contract with institutions of higher education and state education agencies for educational research.

1954 Brown v. Board of Education: held unconstitutional the deliberate segregation of schools by law on account of race

1958 National Defense Education Act: provided extensive aid to schools and students.

1962 Engel v. Vitale: Supreme Court ruled that the state could not enforce prayer in public schools.

1963 Vocational Education Act: further expanded agricultural extension.

1964 Civil Rights Act, Title IX of the Education Amendments of 1972 and Section 1983 of the 1964 Act: outlaws discrimination by sex and protects students from receiving different resources and other disparate treatment on account of sex.

1965 Head Start: established in the Office of Economic Opportunity as a way to serve children of low-income families; later administered by the Administration for Children and Families. 
1973 Federal Pell Grant Program: authorized under the Higher Education Act of 1965, provides for undergraduate student aid based on need.

1975 Education for All Handicapped Children Act (EAHCA): requires better access to schools for disabled students.

1975 Individuals with Disabilities Education Act (IDEA): replaces EAHCA and addresses the failure of many states to comply with EAHCA.

1978 University of California Regents v. Bakke: Supreme Court rules against reverse discrimination, fixed quotas cannot be set.

1980 Department of Education: established as a separate cabinet-level agency. 


\section{Data Series Table of Contents for \\ Education Chapter (old Historical Statistics Series H 412-787)}

(Note: Only tables in bold are included with this essay.)

\section{Educational Flow}

A. K-12, public and private

CG.A.1 Public school districts and elementary and secondary schools, 1916-1996

CG.A.2 Public and private enrollments, grades K-8 and 9-12: 1869-70 to fall 1996

CG.A.3 Enrollment in public elementary and secondary schools, by grade: 1910-11 to 1995-96

CG.A.4 School enrollment and school enrollment rates, by age and sex: 1940 to 1995

CG.A.5 Children served in special education programs, by type of disability, 1921-22 to 1995-96

CG.A.6 Average daily attendance and the average school term of public elementary and secondary schools: 1869-70 to 1994-95

CG.A.7 Public elementary and secondary day school teachers and instructional staff, counts and average annual salaries: 1869-70 to 1994-95

CG.A.8 Catholic elementary and secondary schools, enrollment, and staff: 1920 to 1996

CG.A.9 Public school enrollment by subject in grades nine to twelve: 1889-90 to 1981-82

CG.A.10 Average number of Carnegie units earned by public high school graduates in various subject fields, by race and sex: 1982 to 1994

CG.A.11 High school graduates, by sex and control of institution: 1870 to 1997

CGA.12 General Educational Development (GED) credentials issued, and number and age distribution of test takers: United States and outlying areas, 1971 to 1995

CG.A.13 Student proficiency in reading, mathematics, and writing, as measured by the National Assessment of Educational Progress (NAEP), by age, sex, and race/ethnicity: 1971 to 1996

CG.A.14 Enrollment of 3 to 5 year olds in preprimary programs: 1965 to 1996

CG.A.15 School enrollment per 100 5- to 19-year-olds, by sex and race: 1850 to 1994

CG.A.16 Unionization of teachers and instructional staff: NEA and AFT membership and union density measures, 1960 to 1997

CG.A.17 Public and private secondary school graduation rates, by census division and race: 1910 to 1962

CG.A.18 Public and private secondary school enrollment rates, by census division: 1910 to 1962

CG.A.19 Private secondary school graduates as a fraction of all secondary school graduates, by census division: 1910 to 1962

\section{B. Higher Education}

CG.B.1 Number of institutions of higher education, by control and type: 1869-70 to 199596

CG.B.2 Enrollment in institutions of higher education, by sex, attendance status, and type and control of institution: 1869-70 to fall 1995 
CG.B.3 Degrees conferred by institutions of higher education, by sex and level: 1869-70 to 1994-95

CG.B.4 Doctorate degrees conferred by institutions of higher education, by field of study: 1920 to $1994-95$

CG.B.5 Bachelors degrees conferred by institutions of higher education, by field of study: 1959-60 to 1994-95

CG.B.6 Professional staff, by sex, and instructional staff, by control, at institutions of higher education: 1869-70 to 1993-94

CG.B.7 Fall enrollment in "historically black" colleges and total college enrollment among non-Hispanic African-Americans: 1976 to 1995

\section{Educational Stock}

CG.C.1 Years of school or highest grade completed by persons 25 years old and over, by sex, race and ethnicity: April 1940 to March 1997

CG.C.2 Percentage illiterate among persons 14 years old and over, by race and nativity: 1870 to 1979

\section{Educational Finance}

\section{A. K-12 (public and private)}

CG.D.1 Revenues for public elementary and secondary schools, by source of funds: 188990 to $1995-96$

CG.D.2 Total and current expenditures and expenditure per pupil in public elementary and secondary schools, by purpose: 1869-70 to 1994-95

CG.D.3 Private elementary and secondary school receipts and expenditures, by purpose: 1930 to 1970

CG.D.4 Public school pupils transported at public expense and current expenditures for transportation: 1929-30 to 1994-95

\section{B. Higher Education}

CG.E.1 Current-fund revenue of institutions of higher education, by source of funds: 1889-90 to 1994-95

CG.E.2 Current-fund expenditures and educational and general expenditures per student of institutions of higher education, by function: 1929-30 to 1994-95

CG.E.3 Value of property and endowment, and liabilities of institutions of higher education: 1899-1900 to 1994-95

CG.E.4 Average undergraduate tuition and fees and board rates paid by students in institutions of higher education, by type and control of institution: 1964-65 to 1996-97

\section{Returns to Education}

CG.F.1 Mean annual income of persons twenty-five years old and over by years of school completed, sex, and full-time, year-round work status: 1939 to 1996

CG.F.2 Median annual income of persons twenty-five years old and over by years of school completed, sex, and full-time, year-round work status: 1939 to 1996 
<CG.A.1> Public school districts and elementary and secondary schools: 1916 to $1996^{1}$

\begin{tabular}{|c|c|c|c|c|c|c|}
\hline \multirow{3}{*}{$\begin{array}{c}\text { School year } \\
\text { ending }\end{array}$} & \multirow{3}{*}{$\begin{array}{l}\text { School } \\
\text { districts }^{2,3}\end{array}$} & \multicolumn{5}{|c|}{ Number of schools } \\
\hline & & \multicolumn{2}{|l|}{ Elementary } & \multicolumn{2}{|c|}{ Secondary } & \multirow{2}{*}{$\begin{array}{l}\text { One-teacher public } \\
\text { schools }^{6}\end{array}$} \\
\hline & & Public $^{1,4,5}$ & Private & Public $^{1,4,5}$ & Private & \\
\hline Units & Number & Number & Number & Number & Number & Number \\
\hline HS no. & H412 & H413 & H414 & H415 & H416 & H417 \\
\hline col. no. & (1) & (2) & (3) & (4) & (5) & (6) \\
\hline 1916 & $\begin{array}{ll}-1 \\
-\cdots--\end{array}$ & - & - & $\begin{array}{ll}-1 \\
-\cdots--\end{array}$ & -1 & 200,100 \\
\hline 1918 & ----- & $\begin{array}{ll}--- \\
-\cdots\end{array}$ & ----- & ----- & ----- & 196,000 \\
\hline 1920 & $\begin{array}{l}---- \\
-\end{array}$ & $\begin{array}{c}---- \\
-\end{array}$ & $\begin{array}{c}---- \\
-\end{array}$ & ----- & ----- & 190,700 \\
\hline 1922 & ----- & $----\cdot$ & ----- & ----- & ----- & 180,800 \\
\hline 1924 & $\begin{array}{ll}---- \\
-\end{array}$ & ----- & ----- & ----- & ----- & 169,700 \\
\hline 1926 & $\begin{array}{ll}--- \\
--\end{array}$ & ---- & $\begin{array}{ll}--- \\
-\cdots\end{array}$ & $\begin{array}{ll}--- \\
-\cdots\end{array}$ & ----- & 162,800 \\
\hline 1928 & $\begin{array}{ll}---- \\
--1\end{array}$ & ----- & $\begin{array}{c}---- \\
-\end{array}$ & ----- & $\begin{array}{ll}---- \\
-\end{array}$ & 156,100 \\
\hline 1930 & ---- & 247,581 & 238,306 & 27,188 & 23,930 & 149,282 \\
\hline 1932 & 127,531 & 242,484 & 232,750 & 29,698 & 26,409 & 143,391 \\
\hline 1934 & (NA) & 246,228 & 236,236 & 28,041 & 24,714 & 139,166 \\
\hline 1936 & (NA) & 242,166 & 232,174 & 28,979 & 25,652 & 131,101 \\
\hline 1938 & 119,001 & 231,652 & 221,660 & 28,794 & 25,467 & 121,178 \\
\hline 1940 & 117,108 & (NA) & (NA) & (NA) & (NA) & 113,600 \\
\hline 1942 & 115,493 & 193,397 & 183,112 & 28,134 & 25,123 & 107,692 \\
\hline 1944 & 111,383 & 180,190 & 169,905 & 31,984 & 28,973 & 96,302 \\
\hline 1946 & 101,382 & 170,090 & 160,227 & 27,608 & 24,314 & 86,563 \\
\hline 1948 & 94,926 & 156,831 & 146,760 & 28,776 & 25,484 & 75,096 \\
\hline 1950 & 83,718 & 138,600 & 128,225 & 27,873 & 24,542 & 59,652 \\
\hline 1952 & 71,094 & 134,429 & 123,763 & 27,068 & 23,746 & 50,742 \\
\hline 1954 & 63,057 & 122,614 & 110,875 & 29,550 & 25,637 & 42,865 \\
\hline 1956 & 54,859 & 116,799 & 104,427 & 29,933 & 26,046 & 34,964 \\
\hline 1958 & 47,594 & 108,511 & 95,446 & 29,501 & 25,507 & 25,341 \\
\hline $1960^{*}$ & 40,520 & 105,427 & 91,853 & 29,845 & 25,784 & 20,213 \\
\hline 1962 & 35,676 & 96,672 & 81,910 & 29,479 & 25,350 & 13,333 \\
\hline 1964 & 31,705 & (NA) & 77,584 & 30,882 & 26,431 & 9,895 \\
\hline 1966 & 26,983 & 88,556 & 73,216 & 31,203 & 26,597 & 6,491 \\
\hline 1968 & 22,010 & 85,779 & 70,879 & 31,311 & 27,011 & 4,146 \\
\hline 1970 & (NA) & (NA) & (NA) & (NA) & (NA) & (NA) \\
\hline 1971 & 17,995 & 80,172 & 65,800 & 29,122 & 25,352 & 1,815 \\
\hline 1972 & (NA) & (NA) & (NA) & (NA) & (NA) & (NA) \\
\hline 1973 & (NA) & (NA) & (NA) & (NA) & (NA) & (NA) \\
\hline 1974 & 16,730 & (NA) & 65,070 & (NA) & 25,906 & 1,365 \\
\hline 1975 & (NA) & (NA) & (NA) & (NA) & (NA) & (NA) \\
\hline 1976 & 16,376 & (NA) & 63,242 & (NA) & 25,330 & 1,166 \\
\hline 1977 & 16,271 & 79,029 & 62,644 & 31,282 & 25,378 & 1,111 \\
\hline 1978 & (NA) & (NA) & (NA) & (NA) & (NA) & (NA) \\
\hline 1979 & 16,014 & 78,079 & 61,982 & 30,270 & 24,504 & 1,056 \\
\hline 1980 & (NA) & (NA) & (NA) & (NA) & (NA) & (NA) \\
\hline 1981 & 15,912 & 77,861 & 61,069 & 30,040 & 24,362 & 921 \\
\hline 1982 & (NA) & (NA) & (NA) & (NA) & (NA) & $(\mathrm{NA})$ \\
\hline 1983 & 15,824 & (NA) & 59,656 & (NA) & 23,988 & 798 \\
\hline 1984 & 15,747 & 79,954 & 59,082 & 31,809 & 23,947 & 838 \\
\hline 1985 & (NA) & (NA) & 58,827 & (NA) & 23,916 & 825 \\
\hline 1986 & (NA) & (NA) & (NA) & (NA) & (NA) & (NA) \\
\hline 1987 & 15,713 & (NA) & 60,784 & (NA) & 23,389 & 763 \\
\hline 1988 & 15,577 & 82,704 & 59,754 & 32,259 & 23,841 & 729 \\
\hline 1989 & 15,376 & (NA) & 60,176 & (NA) & 23,638 & 583 \\
\hline 1990 & 15,367 & (NA) & 60,699 & (NA) & 23,461 & 630 \\
\hline 1991 & 15,358 & 83,563 & 61,340 & 32,449 & 23,460 & 617 \\
\hline 1992 & 15,173 & 85,262 & 61,739 & 32,530 & 23,248 & 569 \\
\hline 1993 & 15,025 & (NA) & 62,225 & (NA) & 23,220 & 430 \\
\hline 1994 & 14,881 & 86,269 & 62,726 & 33,934 & 23,379 & 442 \\
\hline 1995 & 14,772 & (NA) & 63,572 & (NA) & 23,668 & 458 \\
\hline 1996 & 14,883 & $(\mathrm{NA})$ & 63,961 & (NA) & 23,793 & 474 \\
\hline
\end{tabular}


Sources: <CG.A.1.1> through <CG.A.1.6>, 1916-1956, U.S. Bureau of the Census, Historical Statistics of the United States (Washington, D.C.: U.S. G.P.O., 1975), series H 412 to H 417. The original sources are: 1916, U.S. Office of Education, Annual Report of the United States Commissioner of Education; 1918-1956, U.S. Office of Education, Biennial Survey of Education in the United States, Statistics of State School Systems, various issues. 1958-1996, U.S. Department of Education, Digest of Education Statistics 1997 (Washington, D.C.: U.S. G.P.O., 1997), table 89.

A school is defined as a division of the school system consisting of a group of pupils composed of one or more grades, organized as one unit with one or more teachers to give instruction of a defined type, and housed in a school plant of one or more buildings. More than one school may be housed in one school plant, as is the case when the elementary and secondary programs are housed in the same school plant. The actual operation of schools is generally the responsibility of local school systems. The local basic administrative unit or school district, $\langle$ CG.A.1.1 $\rangle$, is an area organized as a quasi-corporation under the jurisdiction of an elected or appointed board of education responsible for the administration of all public schools in the area. School districts provide the machinery through which local control of schools is exercised, and are largely responsible for the location and size of schools, the types of educational programs and services offered, and the amount of financial support to be provided locally.

One-teacher public schools, <CG.A.1.6>, are those in which one teacher is employed to teach all grades authorized in the school, regardless of the number of rooms in the building.

A public school is defined as one operated by publicly elected or appointed school officials in which the program and activities are under the control of these officials and which is supported by public funds. School data, prior to 1960, are for public elementary and secondary day schools in the contiguous United States. Excluded are public schools in the outlying areas of the United States, public schools operated directly by the Federal Government on military reservations and schools for Native Americans, public residential schools for special needs children, and subcollegiate departments of institutions of higher education. Beginning in 1960, public schools in Alaska and Hawaii are included in the data.

Nonpublic schools, while subject to certain regulatory controls of the state, are under the operational control of private individuals or church-affiliated or nonsectarian institutions. Whether operated on a profit or nonprofit basis, nonpublic schools are generally supported by private funds as distinguished from public funds.

Footnotes:

11: Schools with both elementary and secondary programs are included both under elementary and secondary headings.

12: Includes operating and nonoperating districts.

13: Because of expanded survey coverage, data after the school year ending in 1984 are not directly comparable with figures for earlier years.

14: Data for private schools in most years are partly estimated.

15: Data for private schools after the school year ending in 1983 are from sample surveys and should not be compared directly to the data for earlier years.

16: The wording in the reports changes over time from "one-room schoolhouse" to "one-teacher schoolhouse," but they appear to be measuring the same construct.

17: Data prior to 1930 are estimated on the basis of the number of schools that responded to state surveys, whereas subsequent data are the number of schools on file with the state, not all of which responded to the surveys.

* Alaska and Hawaii are included in and after this year. 
$<$ CG.A.2> Public and private enrollments, grades K-8 and 9-12: 1869-70 to fall $1996^{1}$

\begin{tabular}{|c|c|c|c|c|c|c|c|c|c|c|c|c|}
\hline \multirow[b]{2}{*}{ School year } & \multicolumn{2}{|c|}{$\begin{array}{l}\text { All Public and private } \\
\text { schools }\end{array}$} & \multicolumn{5}{|c|}{ Public Schools } & \multicolumn{5}{|c|}{ Private Schools } \\
\hline & \begin{tabular}{|c|} 
Total \\
enrollment, \\
kinder- \\
garten to \\
grade 12 \\
\end{tabular} & $\begin{array}{c}\text { Ratio of } \\
\text { kinder- } \\
\text { garten to } \\
\text { grade } 12 \\
\text { enrollment } \\
\text { to } 5 \text { - to } 17- \\
\text { year olds }\end{array}$ & $\begin{array}{c}\text { Total } \\
\text { enrollment, } \\
\text { kinder- } \\
\text { garten to } \\
\text { grade } 12\end{array}$ & $\begin{array}{l}\text { Kinder- } \\
\text { garten to } \\
\text { grade } 8\end{array}$ & $\begin{array}{c}\text { (Pupils/ } \\
\text { teachers), } \\
\text { kinder- } \\
\text { garten to } \\
\text { grade } 8^{2}\end{array}$ & $\begin{array}{c}\text { Grades } 9 \\
\text { to } 12\end{array}$ & $\begin{array}{c}\text { (Pupils/ } \\
\text { teachers), } \\
\text { grades } 9 \text { to } \\
12^{2}\end{array}$ & $\begin{array}{c}\text { Total } \\
\text { enrollment, } \\
\text { kinder- } \\
\text { garten to } \\
\text { grade } 12^{3}\end{array}$ & $\begin{array}{l}\text { Kinder- } \\
\text { garten to } \\
\text { grade } 8^{3}\end{array}$ & \begin{tabular}{|c|} 
(Pupils/ \\
teachers), \\
kinder- \\
garten to \\
grade $8^{2,3}$
\end{tabular} & $\begin{array}{c}\text { Grades } 9 \\
\text { to } 12^{3}\end{array}$ & $\begin{array}{c}\text { (Pupils/ } \\
\text { teachers), } \\
\text { grades } 9 \text { to } \\
12^{2,3}\end{array}$ \\
\hline Units & thousands & percentage & thousands & thousands & percentage & thousands & percentage & thousands & thousands & percentage & thousands & percentage \\
\hline HS no. & H418 & H419 & $\mathrm{H} 420$ & New & H423 & H424 & H425 & H426 & H427 & H428 & H429 & $\mathrm{H} 430$ \\
\hline col. No. & (1) & (2) & (3) & (4) & (5) & (6) & (7) & (8) & (9) & (10) & (11) & (12) \\
\hline $1869-70$ & $\begin{array}{ll}--- \\
\end{array}$ & $57.0^{4}$ & 6,872 & $\begin{array}{ll}--- \\
\end{array}$ & $\begin{array}{ll}--- \\
\end{array}$ & $\begin{array}{l}--- \\
-\end{array}$ & $\begin{array}{ll}--- \\
\end{array}$ & $\begin{array}{l}---- \\
\end{array}$ & $\begin{array}{l}---- \\
\end{array}$ & $\begin{array}{l}--- \\
-\end{array}$ & $\begin{array}{l}---- \\
-\end{array}$ & $\begin{array}{l}---- \\
\end{array}$ \\
\hline $1870-71$ & ---- & (NA) & 7,562 & 7,481 & ---- & 80 & ---- & ----- & ----- & $\begin{array}{ll}--- \\
\end{array}$ & ----- & ----- \\
\hline $1871-72$ & ---- & (NA) & 7,815 & (NA) & ---- & (NA) & ---- & ----- & ----- & ---- & ----- & ----- \\
\hline $1872-73$ & ---- & (NA) & 8,004 & (NA) & ---- & (NA) & ---- & ----- & ----- & ---- & ----- & ----- \\
\hline $1873-74$ & ---- & (NA) & 8,444 & (NA) & ---- & (NA) & ---- & ----- & ----- & ---- & ----- & ----- \\
\hline $1874-75$ & ---- & (NA) & 8,786 & (NA) & $\begin{array}{l}--- \\
\end{array}$ & (NA) & ---- & ----- & ----- & ---- & ----- & ----- \\
\hline $1875-76$ & ---- & (NA) & 8,869 & (NA) & ---- & (NA) & ---- & ----- & ----- & ---- & ----- & ----- \\
\hline 1876-77 & ---- & (NA) & 8,965 & (NA) & ---- & (NA) & ---- & ----- & ----- & ---- & ----- & ----- \\
\hline 1877-78 & ---- & (NA) & 9,439 & (NA) & ---- & (NA) & ---- & ----- & ----- & ---- & ----- & ----- \\
\hline $1878-79$ & ---- & (NA) & 9,504 & (NA) & ---- & (NA) & ---- & ----- & ----- & ---- & ----- & ----- \\
\hline $1879-80$ & ---- & $65.5^{4}$ & 9,868 & 9,757 & ---- & 110 & ---- & ----- & ----- & ---- & ----- & ----- \\
\hline $1880-81$ & ---- & (NA) & 10,001 & (NA) & ---- & (NA) & ---- & ----- & ----- & ---- & ----- & ----- \\
\hline 1881-82 & ---- & (NA) & 10,212 & (NA) & ---- & (NA) & ---- & ----- & ----- & ---- & ----- & ----- \\
\hline $1882-83$ & ---- & (NA) & 10,652 & (NA) & ---- & (NA) & ---- & ----- & ----- & ---- & ----- & ----- \\
\hline $1883-84$ & ---- & (NA) & 10,982 & (NA) & ---- & (NA) & $\begin{array}{l}--- \\
\end{array}$ & ----- & ----- & ---- & ----- & ----- \\
\hline $1884-85$ & ---- & (NA) & 11,398 & (NA) & ---- & (NA) & ---- & ----- & ----- & ---- & ----- & ----- \\
\hline $1885-86$ & ---- & (NA) & 11,664 & (NA) & ---- & (NA) & ---- & ----- & ----- & ---- & ----- & ----- \\
\hline $1886-87$ & ---- & (NA) & 11,885 & (NA) & ---- & (NA) & ---- & ----- & ----- & ---- & ----- & ----- \\
\hline $1887-88$ & ---- & (NA) & 12,183 & (NA) & ---- & (NA) & ---- & ----- & ----- & ---- & ----- & ----- \\
\hline 1888-89 & 13,661 & (NA) & 12,392 & (NA) & ---- & (NA) & ---- & 1,269 & ----- & ---- & ----- & ----- \\
\hline $1889-90$ & 14,334 & 77.3 & 12,723 & $12520^{5}$ & ---- & 203 & ---- & 1,611 & $1,516^{5}$ & ---- & 95 & 13.2 \\
\hline $1890-91$ & 14,541 & (NA) & 13,050 & 12,839 & ---- & 212 & ---- & 1,491 & 1,392 & ---- & 98 & (NA) \\
\hline
\end{tabular}


$<$ CG.A.2> continued

\begin{tabular}{|c|c|c|c|c|c|c|c|c|c|c|c|c|}
\hline \multirow[b]{2}{*}{ School year } & \multicolumn{2}{|c|}{$\begin{array}{l}\text { All Public and private } \\
\text { schools }\end{array}$} & \multicolumn{5}{|c|}{ Public Schools } & \multicolumn{5}{|c|}{ Private Schools } \\
\hline & \begin{tabular}{|c|} 
Total \\
enrollment, \\
kinder- \\
garten to \\
grade 12
\end{tabular} & 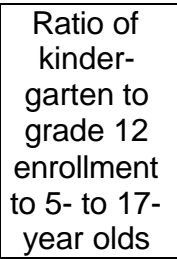 & \begin{tabular}{|c|} 
Total \\
enrollment, \\
kinder- \\
garten to \\
grade 12
\end{tabular} & $\begin{array}{l}\text { Kinder- } \\
\text { garten to } \\
\text { grade } 8\end{array}$ & $\begin{array}{c}\text { (Pupils/ } \\
\text { teachers), } \\
\text { kinder- } \\
\text { garten to } \\
\text { grade } 8^{2}\end{array}$ & $\begin{array}{c}\text { Grades } 9 \\
\text { to } 12\end{array}$ & \begin{tabular}{|c|} 
(Pupils/ \\
teachers), \\
grades 9 to \\
$12^{2}$
\end{tabular} & $\begin{array}{c}\text { Total } \\
\text { enrollment, } \\
\text { kinder- } \\
\text { garten to } \\
\text { grade } 12^{3}\end{array}$ & $\begin{array}{l}\text { Kinder- } \\
\text { garten to } \\
\text { grade } 8^{3}\end{array}$ & $\begin{array}{c}\text { (Pupils/ } \\
\text { teachers), } \\
\text { kinder- } \\
\text { garten to } \\
\text { grade } 8^{2,3}\end{array}$ & $\begin{array}{c}\text { Grades } 9 \\
\text { to } 12^{3}\end{array}$ & $\begin{array}{c}\text { (Pupils/ } \\
\text { teachers), } \\
\text { grades } 9 \text { to } \\
12^{2,3}\end{array}$ \\
\hline Units & thousands & percentage & thousands & thousands & percentage & thousands & percentage & thousands & thousands & percentage & thousands & percentage \\
\hline HS no. & H418 & H419 & $\mathrm{H} 42 \mathrm{O}$ & New & $\mathrm{H} 423$ & H424 & H425 & H426 & H427 & H428 & H429 & $\mathrm{H} 430$ \\
\hline col. No. & (1) & (2) & (3) & (4) & (5) & (6) & (7) & (8) & (9) & (10) & (11) & (12) \\
\hline $1891-92$ & 14,556 & (NA) & 13,256 & 13,016 & ---- & 240 & ---- & 1,300 & 1,199 & $\begin{array}{ll}--- \\
\end{array}$ & 101 & (NA) \\
\hline $1892-93$ & 14,826 & (NA) & 13,483 & 13,229 & ---- & 254 & $\begin{array}{ll}--- \\
\end{array}$ & 1,343 & 1,240 & ---- & 102 & (NA) \\
\hline $1893-94$ & 15,314 & (NA) & 13,995 & 13,706 & ---- & 289 & $\begin{array}{ll}--- \\
\end{array}$ & 1,319 & 1,200 & ---- & 119 & (NA) \\
\hline $1894-95$ & 15,455 & (NA) & 14,244 & 13,894 & ---- & 350 & ---- & 1,211 & 1,093 & ---- & 118 & (NA) \\
\hline $1895-96$ & 15,834 & (NA) & 14,499 & 14,118 & ---- & 380 & ---- & 1,335 & 1,228 & ---- & 107 & (NA) \\
\hline $1896-97$ & 16,140 & (NA) & 14,823 & 14,414 & ---- & 409 & ---- & 1,317 & 1,209 & ---- & 108 & (NA) \\
\hline $1897-98$ & 16,459 & (NA) & 15,104 & 14,654 & ---- & 450 & ---- & 1,355 & 1,250 & ---- & 105 & (NA) \\
\hline $1898-99$ & 16,474 & (NA) & 15,176 & 14,700 & ---- & 476 & ---- & 1,298 & 1,194 & ---- & 104 & (NA) \\
\hline $1899-1900$ & 16,855 & 78.1 & 15,503 & 14,984 & ---- & 519 & ---- & 1,352 & 1,241 & ---- & 111 & 10.9 \\
\hline $1900-01$ & 17,072 & 79.3 & 15,703 & 15,161 & ---- & 542 & ---- & 1,370 & 1,262 & ---- & 108 & (NA) \\
\hline 1901-02 & 17,126 & 78.6 & 15,917 & 15,367 & $\begin{array}{l}--- \\
\end{array}$ & 551 & ---- & 1,209 & 1,104 & ---- & 105 & (NA) \\
\hline 1902-03 & 17,205 & 77.9 & 16,009 & 15,417 & ---- & 592 & ---- & 1,196 & 1,094 & ---- & 102 & (NA) \\
\hline $1903-04$ & 17,560 & 78.7 & 16,256 & 15,620 & ---- & 636 & ---- & 1,304 & 1,201 & ---- & 103 & (NA) \\
\hline 1904-05 & 17,806 & 78.8 & 16,468 & 15,789 & ---- & 680 & ---- & 1,338 & 1,231 & ---- & 107 & (NA) \\
\hline 1905-06 & 18,056 & 79.0 & 16,642 & 15,919 & ---- & 723 & ---- & 1,414 & 1,312 & ---- & 102 & (NA) \\
\hline 1906-07 & 18,292 & 79.1 & 16,891 & 16,140 & ---- & 751 & ---- & 1,402 & 1,305 & ---- & 97 & (NA) \\
\hline 1907-08 & 18,537 & 79.2 & 17,062 & 16,292 & ---- & 770 & ---- & 1,475 & 1,383 & ---- & 92 & (NA) \\
\hline 1908-09 & 18,917 & 79.9 & 17,506 & 16,665 & ---- & 841 & ---- & 1,411 & 1,317 & ---- & 94 & (NA) \\
\hline 1909-10 & 19,372 & 80.7 & 17,814 & 16,899 & 34.4 & 915 & ---- & 1,558 & 1,441 & ---- & 117 & 10.5 \\
\hline $1910-11$ & 19,636 & 80.5 & 18,035 & 17,050 & (NA) & 985 & $\begin{array}{l}--- \\
\end{array}$ & 1,601 & 1,471 & ---- & 131 & (NA) \\
\hline 1911-12 & 19,830 & 80.3 & 18,183 & 17,078 & (NA) & 1,105 & ---- & 1,647 & 1,506 & ---- & 141 & (NA) \\
\hline $1912-13$ & 20,348 & 81.3 & 18,609 & 17,474 & (NA) & 1,135 & ---- & 1,739 & 1,591 & ---- & 148 & (NA) \\
\hline 1913-14 & 20,935 & 82.1 & 19,154 & 17,935 & (NA) & 1,219 & ---- & 1,781 & 1,626 & ---- & 155 & (NA) \\
\hline
\end{tabular}


$<$ CG.A.2> continued

\begin{tabular}{|c|c|c|c|c|c|c|c|c|c|c|c|c|}
\hline \multirow[b]{2}{*}{ School year } & \multicolumn{2}{|c|}{$\begin{array}{l}\text { All Public and private } \\
\text { schools }\end{array}$} & \multicolumn{5}{|c|}{ Public Schools } & \multicolumn{5}{|c|}{ Private Schools } \\
\hline & \begin{tabular}{|c|} 
Total \\
enrollment, \\
kinder- \\
garten to \\
grade 12
\end{tabular} & 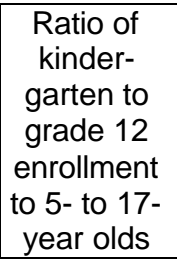 & \begin{tabular}{|c|} 
Total \\
enrollment, \\
kinder- \\
garten to \\
grade 12
\end{tabular} & $\begin{array}{l}\text { Kinder- } \\
\text { garten to } \\
\text { grade } 8\end{array}$ & $\begin{array}{c}\text { (Pupils/ } \\
\text { teachers), } \\
\text { kinder- } \\
\text { garten to } \\
\text { grade } 8^{2}\end{array}$ & $\begin{array}{c}\text { Grades } 9 \\
\text { to } 12\end{array}$ & \begin{tabular}{|c|} 
(Pupils/ \\
teachers), \\
grades 9 to \\
$12^{2}$
\end{tabular} & $\begin{array}{c}\text { Total } \\
\text { enrollment, } \\
\text { kinder- } \\
\text { garten to } \\
\text { grade } 12^{3}\end{array}$ & $\begin{array}{l}\text { Kinder- } \\
\text { garten to } \\
\text { grade } 8^{3}\end{array}$ & $\begin{array}{c}\text { (Pupils/ } \\
\text { teachers), } \\
\text { kinder- } \\
\text { garten to } \\
\text { grade } 8^{2,3}\end{array}$ & $\begin{array}{c}\text { Grades } 9 \\
\text { to } 12^{3}\end{array}$ & $\begin{array}{c}\text { (Pupils/ } \\
\text { teachers), } \\
\text { grades } 9 \text { to } \\
12^{2,3}\end{array}$ \\
\hline Units & thousands & percentage & thousands & thousands & percentage & thousands & percentage & thousands & thousands & percentage & thousands & percentage \\
\hline HS no. & H418 & H419 & $\mathrm{H} 42 \mathrm{O}$ & New & $\mathrm{H} 423$ & H424 & H425 & H426 & H427 & H428 & H429 & $\mathrm{H} 430$ \\
\hline col. No. & (1) & (2) & (3) & (4) & (5) & (6) & (7) & (8) & (9) & (10) & (11) & (12) \\
\hline $1914-15$ & 21,474 & 82.7 & 19,704 & 18,375 & (NA) & 1,329 & ---- & 1,770 & 1,615 & $\begin{array}{ll}--- \\
\end{array}$ & 155 & (NA) \\
\hline $1915-16$ & 22,172 & 84.2 & 20,352 & 18,896 & (NA) & 1,456 & $\begin{array}{ll}--- \\
\end{array}$ & 1,820 & 1,665 & ---- & 157 & (NA) \\
\hline 1917-18 & 22,516 & 83.1 & 20,854 & 18,920 & 32.6 & 1,934 & 23.0 & 1,662 & 1,504 & ---- & 159 & (NA) \\
\hline $1919-20$ & 23,278 & 84.4 & 21,578 & 19,378 & 33.6 & 2,200 & 21.6 & 1,699 & 1,486 & ---- & 214 & 12.3 \\
\hline $1921-22$ & 24,820 & 87.1 & 23,239 & 20,366 & 34.3 & 2,873 & 22.2 & 1,581 & 1,355 & ---- & 226 & (NA) \\
\hline $1923-24$ & 26,016 & 86.6 & 24,289 & 20,899 & 33.9 & 3,390 & 23.5 & 1,727 & 1,473 & ---- & 254 & (NA) \\
\hline $1925-26$ & 27,180 & 90.0 & 24,741 & 20,984 & 32.6 & 3,757 & 22.2 & 2,439 & 2,143 & ---- & 296 & (NA) \\
\hline $1927-28$ & 27,810 & 89.9 & 25,180 & 21,268 & 33.1 & 3,911 & 20.7 & 2,631 & 2,289 & ---- & 341 & (NA) \\
\hline $1929-30$ & 28,329 & 90.2 & 25,678 & 21,279 & 33.2 & 4,399 & 20.6 & 2,651 & 2,310 & ---- & 341 & 14.0 \\
\hline 1931-32 & 29,061 & 91.8 & 26,275 & $21,135^{5}$ & 33.0 & 5,140 & 22.2 & 2,786 & $2,383^{5}$ & ---- & 403 & (NA) \\
\hline 1933-34 & 29,163 & 92.4 & 26,434 & $20,765^{5}$ & 33.5 & 5,669 & 24.9 & 2,729 & $2,368^{5}$ & ---- & 360 & (NA) \\
\hline $1935-36$ & 29,006 & 92.4 & 26,367 & $20,393^{5}$ & 33.8 & 5,975 & 22.3 & 2,639 & $2,251^{5}$ & 34.0 & 387 & 15.3 \\
\hline $1937-38$ & 28,663 & 92.6 & 25,975 & 19,748 & 33.2 & 6,227 & 22.0 & 2,687 & 2,241 & 33.4 & 447 & 16.0 \\
\hline $1939-40$ & 28,045 & 93.0 & 25,434 & 18,832 & 32.7 & 6,601 & 22.0 & 2,611 & 2,153 & 33.2 & 458 & 15.2 \\
\hline 1941-42 & 27,179 & 92.3 & 24,562 & 18,175 & 32.5 & 6,388 & 21.3 & 2,617 & 2,133 & 32.6 & 483 & 15.3 \\
\hline $1943-44$ & 25,758 & 89.3 & 23,267 & 17,713 & 32.9 & 5,554 & 19.2 & 2,491 & 2,070 & (NA) & 421 & (NA) \\
\hline $1945-46$ & 26,124 & 91.6 & 23,300 & 17,678 & 32.6 & 5,622 & 19.4 & 2,825 & 2,259 & 35.0 & 565 & 15.5 \\
\hline 1947-48 & 26,998 & 93.2 & 23,945 & 18,291 & 33.0 & 5,653 & 18.5 & 3,054 & 2,451 & 36.4 & 602 & 14.4 \\
\hline $1949-50$ & 28,492 & 94.3 & 25,111 & 19,387 & 32.9 & 5,725 & 17.7 & 3,380 & 2,708 & 35.6 & 672 & 15.9 \\
\hline $1951-52$ & 30,372 & 97.0 & 26,563 & 20,681 & 33.4 & 5,882 & 17.1 & 3,809 & 3,154 & 38.3 & 656 & 15.7 \\
\hline 1953-54 & 33,175 & 96.7 & 28,836 & 22,546 & 34.3 & 6,290 & 16.8 & 4,339 & 3,592 & 42.3 & 747 & 15.2 \\
\hline $1955-56$ & 35,872 & 97.1 & 31,163 & 24,290 & $30.2^{2}$ & 6,873 & $20.9^{2}$ & 4,709 & 3,886 & $40.4^{2}$ & 823 & $15.7^{2}$ \\
\hline $1956-57$ & 37,303 & 97.4 & 32,334 & 25,016 & 29.6 & 7,318 & 21.2 & 4,968 & 4,092 & 38.8 & 877 & 17.3 \\
\hline
\end{tabular}

$-31-$ 
<CG.A.2> continued

\begin{tabular}{|c|c|c|c|c|c|c|c|c|c|c|c|c|}
\hline \multirow[b]{2}{*}{ School year } & \multicolumn{2}{|c|}{$\begin{array}{l}\text { All Public and private } \\
\text { schools }\end{array}$} & \multicolumn{5}{|c|}{ Public Schools } & \multicolumn{5}{|c|}{ Private Schools } \\
\hline & $\begin{array}{c}\text { Total } \\
\text { enrollment, } \\
\text { kinder- } \\
\text { garten to } \\
\text { grade } 12\end{array}$ & 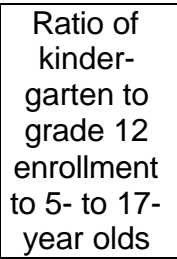 & \begin{tabular}{|c|} 
Total \\
enrollment, \\
kinder- \\
garten to \\
grade 12
\end{tabular} & $\begin{array}{l}\text { Kinder- } \\
\text { garten to } \\
\text { grade } 8\end{array}$ & $\begin{array}{c}\text { (Pupils/ } \\
\text { teachers), } \\
\text { kinder- } \\
\text { garten to } \\
\text { grade } 8^{2}\end{array}$ & $\begin{array}{c}\text { Grades } 9 \\
\text { to } 12\end{array}$ & $\begin{array}{c}\text { (Pupils/ } \\
\text { teachers), } \\
\text { grades } 9 \text { to } \\
12^{2}\end{array}$ & $\begin{array}{c}\text { Total } \\
\text { enrollment, } \\
\text { kinder- } \\
\text { garten to } \\
\text { grade } 12^{3}\end{array}$ & $\begin{array}{l}\text { Kinder- } \\
\text { garten to } \\
\text { grade } 8^{3}\end{array}$ & $\begin{array}{c}\text { (Pupils/ } \\
\text { teachers), } \\
\text { kinder- } \\
\text { garten to } \\
\text { grade } 8^{2,3}\end{array}$ & $\begin{array}{c}\text { Grades } 9 \\
\text { to } 12^{3}\end{array}$ & $\begin{array}{c}\text { (Pupils/ } \\
\text { teachers), } \\
\text { grades } 9 \text { to } \\
12^{2,3}\end{array}$ \\
\hline Units & thousands & percentage & thousands & thousands & percentage & thousands & percentage & thousands & thousands & percentage & thousands & percentage \\
\hline HS no. & H418 & H419 & $\mathrm{H} 42 \mathrm{O}$ & New & $\mathrm{H} 423$ & H424 & H425 & H426 & H427 & H428 & H429 & $\mathrm{H} 430$ \\
\hline col. No. & (1) & (2) & (3) & (4) & (5) & (6) & (7) & (8) & (9) & (10) & (11) & (12) \\
\hline $1957-58$ & 38,756 & 97.7 & 33,529 & 25,669 & 29.1 & 7,860 & 21.3 & 5,227 & 4,297 & 38.4 & 931 & 17.0 \\
\hline $1958-59$ & 40,290 & 97.9 & 34,839 & 26,581 & 28.7 & 8,258 & 21.7 & 5,451 & 4,459 & 38.8 & 993 & 18.9 \\
\hline Fall 1959 & 40,857 & 98.0 & 35,182 & 26,911 & 28.7 & 8,271 & 21.5 & 5,675 & 4,640 & 38.7 & 1,035 & 18.5 \\
\hline Fall 1960* & 43,070 & 97.5 & 37,260 & 28,439 & 28.4 & 8,821 & 21.7 & 5,810 & 4,752 & 36.1 & 1,058 & 18.6 \\
\hline Fall 1961 & 44,146 & 97.5 & 38,253 & 28,686 & 28.3 & 9,566 & 21.7 & 5,893 & 4,765 & 39.0 & 1,128 & 19.0 \\
\hline Fall 1962 & 45,798 & 98.2 & 39,746 & 29,374 & 28.5 & 10,372 & 21.7 & 6,052 & 4,850 & 36.3 & 1,202 & 18.5 \\
\hline Fall 1963 & 47,199 & 98.2 & 41,025 & 29,915 & 28.4 & 11,110 & 21.5 & 6,174 & 4,910 & 35.2 & 1,265 & 18.6 \\
\hline Fall 1964 & 47,716 & 98.1 & 41,416 & 30,025 & 27.9 & 11,391 & 21.5 & 6,300 & 5,000 & 34.2 & 1,300 & 18.3 \\
\hline Fall 1965 & 48,473 & 96.9 & 42,173 & 30,563 & 27.6 & 11,610 & 20.8 & 6,300 & 4,900 & 33.3 & 1,400 & 18.4 \\
\hline Fall 1966 & 49,239 & 97.2 & 43,039 & 31,145 & 26.9 & 11,894 & 20.3 & 6,200 & 4,800 & 32.7 & 1,400 & 18.4 \\
\hline Fall 1967 & 49,891 & 97.1 & 43,891 & 31,641 & 26.3 & 12,250 & 20.3 & 6,000 & 4,600 & 31.1 & 1,400 & 18.4 \\
\hline Fall 1968 & 50,744 & 97.6 & 44,944 & 32,226 & 25.4 & 12,718 & 20.4 & 5,800 & 4,400 & 29.9 & 1,400 & 17.9 \\
\hline Fall 1969 & 51,050 & 97.5 & 45,550 & 32,513 & 24.7 & 13,037 & 20.0 & 5,500 & 4,200 & 27.8 & 1,300 & 16.7 \\
\hline Fall 1970 & 51,257 & 97.5 & 45,894 & 32,558 & 24.3 & 13,336 & 19.8 & 5,363 & 4,052 & 26.5 & 1,311 & 16.4 \\
\hline Fall 1971 & 51,271 & 97.5 & 46,071 & 32,318 & 24.9 & 13,753 & 19.3 & 5,200 & 3,900 & 25.7 & 1,300 & 16.7 \\
\hline Fall 1972 & 50,726 & 97.0 & 45,726 & 31,879 & 23.9 & 13,848 & 19.1 & 5,000 & 3,700 & 24.0 & 1,300 & 16.9 \\
\hline Fall 1973 & 50,445 & 97.2 & 45,445 & 31,401 & 23.0 & 14,044 & 19.3 & 5,000 & 3,700 & 23.6 & 1,300 & 16.5 \\
\hline Fall 1974 & 50,073 & 97.2 & 45,073 & 30,971 & 22.6 & 14,103 & 18.7 & 5,000 & 3,700 & 22.6 & 1,300 & 16.0 \\
\hline Fall 1975 & 49,819 & 97.6 & 44,819 & 30,515 & 21.7 & 14,304 & 18.8 & 5,000 & 3,700 & 21.5 & 1,300 & 15.7 \\
\hline Fall 1976 & 49,478 & 97.7 & 44,311 & 29,997 & 21.8 & 14,314 & 18.5 & 5,167 & 3,825 & 20.9 & 1,342 & 15.8 \\
\hline Fall 1977 & 48,717 & 97.6 & 43,577 & 29,375 & 21.1 & 14,203 & 18.2 & 5,140 & 3,797 & 20.0 & 1,343 & 15.1 \\
\hline Fall 1978 & 47,637 & 97.1 & 42,551 & 28,463 & 21.0 & 14,088 & 17.3 & 5,086 & 3,732 & 20.2 & 1,353 & 15.6 \\
\hline Fall 1979 & 46,651 & 97.1 & 41,651 & 28,034 & 20.6 & 13,616 & 17.2 & 5,000 & 3,700 & 19.7 & 1,300 & 14.8 \\
\hline
\end{tabular}


$<$ CG.A.2> continued

\begin{tabular}{|c|c|c|c|c|c|c|c|c|c|c|c|c|}
\hline \multirow[b]{2}{*}{ School year } & \multicolumn{2}{|c|}{$\begin{array}{c}\text { All Public and private } \\
\text { schools }\end{array}$} & \multicolumn{5}{|c|}{ Public Schools } & \multicolumn{5}{|c|}{ Private Schools } \\
\hline & \begin{tabular}{|c|} 
Total \\
enrollment, \\
kinder- \\
garten to \\
grade 12
\end{tabular} & $\begin{array}{c}\text { Ratio of } \\
\text { kinder- } \\
\text { garten to } \\
\text { grade } 12 \\
\text { enrollment } \\
\text { to } 5 \text { - to } 17- \\
\text { year olds }\end{array}$ & \begin{tabular}{|c|} 
Total \\
enrollment, \\
kinder- \\
garten to \\
grade 12
\end{tabular} & $\begin{array}{l}\text { Kinder- } \\
\text { garten to } \\
\text { grade } 8\end{array}$ & $\begin{array}{c}\text { (Pupils/ } \\
\text { teachers), } \\
\text { kinder- } \\
\text { garten to } \\
\text { grade } 8^{2}\end{array}$ & $\begin{array}{c}\text { Grades } 9 \\
\text { to } 12\end{array}$ & \begin{tabular}{|c|} 
(Pupils/ \\
teachers), \\
grades 9 to \\
$12^{2}$
\end{tabular} & $\begin{array}{c}\text { Total } \\
\text { enrollment, } \\
\text { kinder- } \\
\text { garten to } \\
\text { grade } 12^{3}\end{array}$ & $\begin{array}{l}\text { Kinder- } \\
\text { garten to } \\
\text { grade } 8^{3}\end{array}$ & $\begin{array}{c}\text { (Pupils/ } \\
\text { teachers), } \\
\text { kinder- } \\
\text { garten to } \\
\text { grade } 8^{2,3}\end{array}$ & $\begin{array}{c}\text { Grades } 9 \\
\text { to } 12^{3}\end{array}$ & $\begin{array}{c}\text { (Pupils/ } \\
\text { teachers), } \\
\text { grades } 9 \text { to } \\
12^{2,3}\end{array}$ \\
\hline Units & thousands & percentage & thousands & thousands & percentage & thousands & percentage & thousands & thousands & percentage & thousands & percentage \\
\hline HS no. & H418 & H419 & $\mathrm{H} 42 \mathrm{O}$ & New & H423 & $H 424$ & H425 & H426 & $H 427$ & H428 & $H 429$ & $\mathrm{H} 430$ \\
\hline col. No. & (1) & (2) & (3) & (4) & (5) & (6) & (7) & (8) & (9) & (10) & (11) & (12) \\
\hline Fall 1980 & 46,208 & 97.8 & 40,877 & 27,647 & 20.4 & 13,231 & 16.8 & 5,331 & 3,992 & 18.8 & 1,339 & 15.0 \\
\hline Fall 1981 & 45,544 & 98.3 & 40,044 & 27,280 & 20.3 & 12,764 & 16.9 & 5,500 & 4,100 & 18.6 & 1,400 & 15.2 \\
\hline Fall 1982 & 45,166 & 98.9 & 39,566 & 27,161 & 20.2 & 12,405 & 16.6 & 5,600 & 4,200 & 18.2 & 1,400 & 14.9 \\
\hline Fall 1983 & 44,967 & 99.6 & 39,252 & 26,981 & 19.9 & 12,271 & 16.4 & 5,715 & 4,315 & 18.0 & 1,400 & 14.4 \\
\hline Fall 1984 & 44,908 & 99.9 & 39,208 & 26,905 & 19.7 & 12,304 & 16.1 & 5,700 & 4,300 & 17.7 & 1,400 & 14.4 \\
\hline Fall 1985 & 44,979 & 100.0 & 39,422 & 27,034 & 19.5 & 12,388 & 15.8 & 5,557 & 4,195 & 17.1 & 1,362 & 14.0 \\
\hline Fall 1986 & 45,205 & 100.1 & 39,753 & 27,420 & 19.3 & 12,333 & 15.7 & 5,452 & 4,116 & 16.5 & 1,336 & 13.6 \\
\hline Fall 1987 & 45,488 & 100.4 & 40,008 & 27,933 & 19.3 & 12,076 & 15.2 & 5,479 & 4,232 & 16.4 & 1,247 & 13.1 \\
\hline Fall 1988 & 45,430 & 100.1 & 40,189 & 28,501 & 19.0 & 11,687 & 14.9 & 5,241 & 4,036 & 16.1 & 1,206 & 12.8 \\
\hline Fall 1989 & 45,898 & 101.3 & 40,543 & 29,152 & 19.0 & 11,390 & 14.6 & 5,355 & 4,162 & 15.1 & 1,193 & 11.7 \\
\hline Fall 1990 & 46,448 & 102.5 & 41,217 & 29,878 & 19.0 & 11,338 & 14.6 & 5,232 & 4,095 & 16.1 & 1,137 & 11.3 \\
\hline Fall 1991 & 47,246 & 102.9 & 42,047 & 30,506 & 18.9 & 11,541 & 14.9 & 5,199 & 4,074 & 16.0 & 1,125 & 11.1 \\
\hline Fall 1992 & 48,198 & 103.3 & 42,823 & 31,088 & 18.9 & 11,735 & 15.1 & 5,375 & 4,212 & 16.2 & 1,163 & 11.3 \\
\hline Fall 1993 & 48,936 & 103.2 & 43,465 & 31,504 & 18.8 & 11,961 & 15.2 & 5,471 & 4,280 & 16.3 & 1,191 & 11.5 \\
\hline Fall 1994 & 49,707 & 102.9 & 44,111 & 31,898 & 19.0 & 12,213 & 14.9 & 5,596 & 4,360 & 16.8 & 1,236 & 11.2 \\
\hline Fall $1995(\mathrm{P})$ & 50,528 & 102.5 & 44,840 & 32,341 & 19.1 & 12,500 & 14.9 & 5,688 & 4,427 & 16.7 & 1,260 & 11.3 \\
\hline Fall $1996^{6}$ & $(F)$ & $(F)$ & 45,229 & $(F)$ & $(F)$ & 12,874 & $(F)$ & $(F)$ & $(F)$ & $(\mathrm{F})$ & 1,293 & $(F)$ \\
\hline
\end{tabular}


Sources: <CG.A.2.1> through <CG.A.2.12>, 1869-70 to 1957-58, U.S. Department of Education, 120 Years of American Education: A Statistical Portrait (Washington, D.C.: U.S. G.P.O., 1993), table 9. The original sources are: 1869-70 to 1915-16, U.S. Office of Education, Annual Report of the United States Commissioner of Education, various issues; 1917-18 to 1957-58, U.S. Office of Education, Biennial Survey of Education in the United States, Statistics of State School Systems, various issues; fall 1959 to fall 1996, U.S. Department of Education, Digest of Education Statistics 1997 (Washington, D.C.: U.S. G.P.O., 1997), table 3. When the data in 120 Years differ from those in Digest 1997, the latter is relied on. <CG.A.2.2>, for number of 5-17 year-olds, U.S. Department of Commerce, Bureau of the Census, Current Population Reports, series P-25, nos. 519, 917, 1000, 1022, 1045, 1057, 1092, and U.S. Population Estimates, by Age, Sex, Race, and Hispanic Origin: 1990-1995, PPL-41. <CG.A.2.4>, 191011 to 1915-16, revisions provided by Thomas D. Snyder, of the National Center for Education Statistics. $\langle$ CG.A.2.5>, <CG.A.2.7>, <CG.A.2.10>, and <CG.A.2.12>, for number of teachers, Abbott L. Ferriss, Indicators of Trends in American Education (N.Y.: Russell Sage Foundation, 1969), series B-5, B-6, B-9, and B-10. See also $\langle$ CG.A.7.3> and $\langle$ CG.A.7.4>, but see note $\backslash 2$ to this table.

Enrollment and other figures prior to 1959-60 for public day schools, grades K-12, include just the contiguous United States. Generally excluded from the entire series are public schools in the outlying areas of the United States, public schools operated directly by the federal government on military bases or exclusively for Native Americans, public residential schools for exceptional children, and subcollegiate departments of institutions of higher education. The excluded category represents a small percentage of all schools. There has been no comprehensive data collection effort for these schools in recent years. Only regular day school pupils are included; pupils enrolled in night schools and summer schools are excluded.

Private school figures are not strictly comparable over time. For example, in some of the earlier years, the figures may include enrollment of secondary pupils in subcollegiate departments of institutions of higher education and normal schools. Enrollment figures prior to 1976 do not include private schools for exceptional children or private vocational or trade schools. They cover only regular day school pupils. Summer school pupils are excluded in all years.

The enrollment information in the Biennial Survey of Education was collected at the state level and represents a cumulative count of the total number of different pupils registered at any time during the school year in each state. Pupils enrolled in two or more states during the school year may be counted more than once. Beginning with the fall of 1965, enrollment data come from fall enrollment counts (pupils enrolled in a given school unit on a particular fall date).

Many earlier enrollment series classify enrollments by instructional level (elementary or secondary). National Center of Education Statistics (NCES) now collects enrollment data by grade, not instructional level. Students enrolled in grades K-8 do not necessarily correspond one-to-one with students enrolled in elementary schools, nor do students enrolled in grades 9-12 correspond one-to-one with students enrolled in secondary schools. Junior high schools with grades 7-9 may be classified as secondary schools, though some of their pupils would be considered as enrolled in elementary grades.

The figures for total enrollment per 100 persons, 5-17 years old, series <CG.A.2.2〉, divide the total enrollment numbers, series <CG.A.2.1>, by the number of persons 5-17 years old as of July 1 of the academic year. For example, for fall 1992, the ratio is the result of dividing enrollment for the academic year 1992-93 by the number of persons 5-17 years old on July 1, 1992. This rate has been increasing steadily, and in the 1980s exceeded 100 percent, where it has remained. Several factors cause this result. The population data come from the census, whereas the enrollment data come from reports from state 
school systems. Some immigrants are not included in the census but are included in school enrollment data. The school enrollment data can double-count some students; the census should not. Also, some enrolled students are outside of the 5-17 age range the July before the school year.

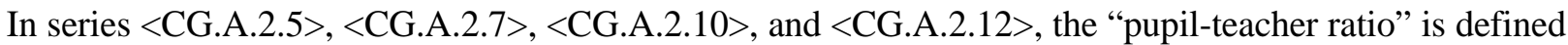
as the number of pupils enrolled divided by the number of classroom teachers. Past series have varied in their methods of counting both pupils and teachers. At times, the pupil counts have been based on average daily attendance or average daily membership, or cumulative enrollment rather than on fall enrollment. Prior to the 1940s, the available figures on "teachers" generally included librarians and guidance and psychological personnel as well as classroom teachers. When considering pupil-teacher ratios by instructional level, there are further complications. Under current NCES data collection practices, teacher data are grouped by instructional level (e.g., elementary, secondary), but the enrollment data, as discussed above, are given by grade level. The mapping from one to the other is not exact in large measure because certain teachers who instruct seventh and eighth grade students often are counted as "secondary school" teachers. After NCES discontinued the collection of teacher and enrollment data by elementary and secondary instructional levels in the mid-1960s, the distribution was estimated based on data collected by the National Education Association (NEA). Proportions of teachers and enrollments by instructional level from the NEA publication "Estimates of School Statistics" were used to distribute counts of teachers and enrollments for the purpose of calculating pupil-teacher ratios by instructional level. The series given here are based on data adjusted for consistency with current definitions, and are not replicable for all years by simply dividing enrollment by teachers. It should also be realized that national averages tend to obscure significant differences in pupil-teacher ratios, such as those between urban and rural areas and between large and small schools.

\section{Footnotes:}

11: Prior to 1965, enrollment data include students who enrolled at any time during the school year. Enrollment ratios based on cumulative enrollment figures tend to be approximately 1 to 2 percentage points higher than counts based on fall enrollment. In later years, data for grades kindergarten through 8 include a relatively small number of pre-kindergarten students. Data for grades 9 to 12 contain a small number of postgraduate students. Population data for 1870 through 1961 include U.S. population overseas; data for later years are for U.S. resident population only. Population data for 1870 to 1890 are from the decennial census. Data for later years are based on counts of population for July 1 preceding the school year. Because of rounding, details may not round to totals.

12: As reported here, the data show a considerable jump between 1954 and 1956. This reflects a change in the calculation of the ratio. Before 1956, some junior high school teachers were classified as secondary school teachers, while their pupils in seventh and eighth grades were classified as elementary school pupils, making K-8 (or elementary) pupil-teacher ratios look higher than they were and 9-12 (or secondary) pupil-teacher ratios look lower than they were. The most recent revisions of these data adjust for this bias back to 1956, but not earlier.

13: For 1958-59 and 1960-61 through 1963-64, numbers were estimated by linear interpolation. Data for most years are at least partially estimated. Beginning in fall 1980, data include estimates for an expanded universe of private schools. Therefore, these totals may differ from figures shown in other tables, and direct comparisons with earlier years should not be made.

14: Underlying data are for public elementary and secondary schools only.

15: Data for 1890 and 1931-32 to 1935-36 exclude kindergarten enrollment; all other years include it to the extent that it was reported. Public kindergarten enrollments become significant in later years. 16: Public elementary and secondary data are based on "Early Estimates" surveys. Other data are projected. 
$<$ CG.A.3> Enrollment in public elementary and secondary schools, by grade: $1910-11$ to $1995-96^{1}$

\begin{tabular}{|c|c|c|c|c|c|c|c|c|c|c|c|c|}
\hline \multirow{2}{*}{ School year } & \multirow[b]{2}{*}{ Total } & \multicolumn{11}{|c|}{ Public Schools, kindergarten through grade 8} \\
\hline & & Total & $\begin{array}{l}\text { Kinder- } \\
\text { garten }^{2}\end{array}$ & Grade 1 & Grade 2 & Grade 3 & Grade 4 & Grade 5 & Grade 6 & Grade 7 & Grade 8 & Ungraded $^{3}$ \\
\hline Units & thousands & thousands & thousands & thousands & thousands & thousands & thousands & thousands & thousands & thousands & thousands & thousands \\
\hline HS no. & new & new & new & new & new & new & new & new & new & new & new & new \\
\hline col. no. & (1) & (2) & (3) & (4) & (5) & (6) & (7) & (8) & (9) & (19) & (11) & (12) \\
\hline $1910-11$ & 18,035 & 16,878 & 327 & 3,890 & 2,450 & 2,301 & 2,201 & 1,870 & 1,523 & 1,258 & 1,059 & $\begin{array}{ll}--- \\
\end{array}$ \\
\hline 1911-12 & 18,183 & 16,982 & 348 & 3,876 & 2,445 & 2,295 & 2,212 & 1,880 & 1,547 & 1,281 & 1,098 & --- \\
\hline $1912-13$ & 18,609 & 17,276 & 370 & 3,922 & 2,468 & 2,316 & 2,248 & 1,910 & 1,589 & 1,319 & 1,133 & ---- \\
\hline 1913-14 & 19,154 & 17,722 & 391 & 3,986 & 2,496 & 2,374 & 2,288 & 1,976 & 1,664 & 1,369 & 1,178 & ---- \\
\hline \begin{tabular}{|l|}
$1914-15$ \\
\end{tabular} & 19,704 & 18,143 & 409 & 4,043 & 2,536 & 2,412 & 2,341 & 2,022 & 1,720 & 1,419 & 1,241 & ---- \\
\hline \begin{tabular}{|l|}
$1915-16$ \\
\end{tabular} & 20,352 & 18,641 & 434 & 4,115 & 2,585 & 2,476 & 2,403 & 2,076 & 1,784 & 1,475 & 1,293 & ---- \\
\hline $1916-17^{5}$ & 20,603 & 18,808 & 434 & 4,225 & 2,600 & 2,504 & 2,426 & 2,105 & 1,814 & 1,481 & 1,219 & ---- \\
\hline \begin{tabular}{|l|}
$1917-18$ \\
\end{tabular} & 20,854 & 18,920 & 433 & 4,323 & 2,608 & 2,524 & 2,441 & 2,128 & 1,839 & 1,483 & 1,141 & ---- \\
\hline $1918-19^{5}$ & 21,216 & 19,149 & 457 & 4,322 & 2,623 & 2,511 & 2,499 & 2,141 & 1,865 & 1,537 & 1,195 & ---- \\
\hline $1919-20$ & 21,578 & 19,378 & 481 & 4,321 & 2,638 & 2,498 & 2,556 & 2,153 & 1,890 & 1,592 & 1,248 & ---- \\
\hline $1920-21^{5}$ & 22,409 & 19,872 & 505 & 4,249 & 2,743 & 2,607 & 2,558 & 2,221 & 1,974 & 1,668 & 1,346 & ---- \\
\hline 1921-22 & 23,239 & 20,366 & 529 & 4,177 & 2,849 & 2,716 & 2,560 & 2,290 & 2,058 & 1,744 & 1,444 & ---- \\
\hline $1922-23^{5}$ & 23,764 & 20,633 & 569 & 4,180 & 2,831 & 2,756 & 2,634 & 2,365 & 2,089 & 1,795 & 1,412 & ---- \\
\hline 1923-24 & 24,289 & 20,899 & 610 & 4,184 & 2,813 & 2,796 & 2,708 & 2,441 & 2,121 & 1,846 & 1,380 & ---- \\
\hline $1924-25^{5}$ & 24,650 & 20,999 & 600 & 4,049 & 2,800 & 2,730 & 2,696 & 2,514 & 2,186 & 1,931 & 1,493 & ---- \\
\hline \begin{tabular}{|l|}
$1925-26$ \\
\end{tabular} & 24,741 & 20,984 & 673 & 3,977 & 2,820 & 2,729 & 2,662 & 2,473 & 2,234 & 1,927 & 1,488 & ---- \\
\hline $1926-27^{5}$ & 24,961 & 21,126 & 684 & 4,074 & 2,818 & 2,696 & 2,647 & 2,454 & 2,239 & 1,974 & 1,539 & ---- \\
\hline 1927-28 & 25,180 & 21,268 & 695 & 4,171 & 2,817 & 2,662 & 2,632 & 2,435 & 2,243 & 2,022 & 1,590 & ---- \\
\hline $1928-29^{5}$ & 25,429 & 21,274 & 709 & 4,161 & 2,810 & 2,697 & 2,616 & 2,409 & 2,250 & 2,026 & 1,596 & --- \\
\hline $1929-30$ & 25,678 & 21,279 & 723 & 4,151 & 2,803 & 2,732 & 2,599 & 2,382 & 2,256 & 2,030 & 1,601 & ---- \\
\hline $1930-31^{5}$ & 25,977 & 21,207 & 712 & 4,041 & 2,790 & 2,698 & 2,594 & 2,423 & 2,267 & 2,041 & 1,641 & ---- \\
\hline \begin{tabular}{|l|}
$1931-32$ \\
\end{tabular} & 26,275 & 21,135 & 701 & 3,930 & 2,776 & 2,664 & 2,589 & 2,463 & 2,278 & 2,053 & 1,682 & ---- \\
\hline $1932-33^{5}$ & 26,355 & 20,950 & 649 & 3,826 & 2,704 & 2,638 & 2,581 & 2,448 & 2,283 & 2,120 & 1,701 & ---- \\
\hline \begin{tabular}{|l|}
$1933-34$ \\
\end{tabular} & 26,434 & 20,765 & 602 & 3,717 & 2,632 & 2,612 & 2,573 & 2,433 & 2,288 & 2,187 & 1,721 & ---- \\
\hline $1934-35^{5}$ & 26,401 & 20,579 & 604 & 3,624 & 2,595 & 2,568 & 2,536 & 2,433 & 2,304 & 2,185 & 1,730 & ---- \\
\hline 1935-36 & 26,367 & 20,393 & 607 & 3,530 & 2,558 & 2,525 & 2,499 & 2,433 & 2,319 & 2,182 & 1,740 & ---- \\
\hline $1936-37^{5}$ & 26,171 & 20,070 & 607 & 3,424 & 2,522 & 2,485 & 2,451 & 2,388 & 2,286 & 2,178 & 1,731 & --- \\
\hline
\end{tabular}

$-36-$ 
$<$ CG.A.3> continued

\begin{tabular}{|c|c|c|c|c|c|c|c|c|c|c|c|c|}
\hline \multirow[b]{2}{*}{ School year } & \multirow[b]{2}{*}{ Total } & \multicolumn{11}{|c|}{ Public Schools, kindergarten through grade 8} \\
\hline & & Total & $\begin{array}{l}\text { Kinder- } \\
\text { garten }^{2}\end{array}$ & Grade 1 & Grade 2 & Grade 3 & Grade 4 & Grade 5 & Grade 6 & Grade 7 & Grade 8 & Ungraded $^{3}$ \\
\hline col. no. & (1) & (2) & (3) & (4) & (5) & (6) & (7) & (8) & (9) & (19) & (11) & (12) \\
\hline $1937-38$ & 25,975 & 19,748 & 607 & 3,317 & 2,487 & 2,444 & 2,403 & 2,342 & 2,253 & 2,173 & 1,722 & $\begin{array}{ll}--- \\
\end{array}$ \\
\hline $1938-39^{5}$ & 25,704 & 19,290 & 601 & 3,168 & 2,410 & 2,388 & 2,362 & 2,295 & 2,214 & 2,140 & 1,712 & ---- \\
\hline $1939-40$ & 25,434 & 18,832 & 595 & 3,018 & 2,333 & 2,332 & 2,322 & 2,248 & 2,176 & 2,108 & 1,701 & ---- \\
\hline $1940-41^{5}$ & 25,296 & 18,582 & 613 & 2,992 & 2,286 & 2,263 & 2,271 & 2,211 & 2,156 & 2,050 & 1,691 & --- \\
\hline \begin{tabular}{|l|}
$1941-42$ \\
\end{tabular} & 24,562 & 18,175 & 626 & 2,931 & 2,215 & 2,175 & 2,197 & 2,166 & 2,124 & 2,061 & 1,680 & --- \\
\hline $1942-43^{5}$ & 24,155 & 18,033 & 665 & 2,919 & 2,229 & 2,180 & 2,149 & 2,102 & 2,071 & 2,023 & 1,695 & ---- \\
\hline \begin{tabular}{|l|}
$1943-44$ \\
\end{tabular} & 23,267 & 17,713 & 697 & 2,879 & 2,221 & 2,163 & 2,080 & 2,017 & 1,998 & 1,965 & 1,694 & ---- \\
\hline $1944-45^{5}$ & 23,226 & 17,666 & 734 & 2,882 & 2,266 & 2,173 & 2,084 & 2,008 & 1,951 & 1,898 & 1,671 & ---- \\
\hline 1945-46 & 23,300 & 17,678 & 773 & 2,895 & 2,319 & 2,191 & 2,094 & 2,006 & 1,910 & 1,837 & 1,654 & ---- \\
\hline $1946-47^{5}$ & 23,659 & 17,821 & 873 & 2,896 & 2,320 & 2,205 & 2,119 & 2,012 & 1,907 & 1,850 & 1,639 & ---- \\
\hline \begin{tabular}{|l|}
$1947-48$ \\
\end{tabular} & 23,945 & 18,291 & 989 & 2,951 & 2,363 & 2,259 & 2,183 & 2,055 & 1,940 & 1,898 & 1,653 & ---- \\
\hline $1948-49^{5}$ & 24,477 & 18,818 & 1,016 & 3,067 & 2,503 & 2,315 & 2,221 & 2,089 & 1,995 & 1,919 & 1,694 & --- \\
\hline \begin{tabular}{|l|}
$1949-50$ \\
\end{tabular} & 25,111 & 19,387 & 1,034 & 3,170 & 2,645 & 2,396 & 2,254 & 2,151 & 2,056 & 1,947 & 1,734 & ---- \\
\hline $1950-51^{5}$ & 25,706 & 19,900 & 941 & 3,053 & 2,739 & 2,600 & 2,358 & 2,211 & 2,117 & 1,995 & 1,885 & ---- \\
\hline \begin{tabular}{|l|}
$1951-52$ \\
\end{tabular} & 26,563 & 20,681 & 1,272 & 2,957 & 2,670 & 2,718 & 2,559 & 2,320 & 2,166 & 2,083 & 1,936 & ---- \\
\hline $1952-53^{5}$ & 27,507 & 21,625 & 1,399 & 3,358 & 2,639 & 2,633 & 2,684 & 2,520 & 2,276 & 2,143 & 1,973 & --- \\
\hline \begin{tabular}{|l|}
$1953-54$ \\
\end{tabular} & 28,836 & 22,546 & 1,474 & 3,666 & 2,940 & 2,569 & 2,565 & 2,607 & 2,449 & 2,242 & 2,032 & ---- \\
\hline $1954-55^{5}$ & 30,045 & 23,471 & 1,415 & 3,518 & 3,391 & 2,896 & 2,535 & 2,523 & 2,584 & 2,432 & 2,177 & ---- \\
\hline $1955-56$ & 31,163 & 24,290 & 1,564 & 3,495 & 3,242 & 3,291 & 2,848 & 2,481 & 2,470 & 2,542 & 2,357 & ---- \\
\hline \begin{tabular}{|l|}
$1956-57$ \\
\end{tabular} & 32,334 & 25,016 & 1,675 & 3,491 & 3,241 & 3,183 & 3,238 & 2,808 & 2,443 & 2,476 & 2,460 & --- \\
\hline \begin{tabular}{|l|}
$1957-58$ \\
\end{tabular} & 33,529 & 25,669 & 1,772 & 3,587 & 3,214 & 3,176 & 3,128 & 3,181 & 2,759 & 2,458 & 2,395 & --- \\
\hline 1958-59 & 34,839 & 26,581 & 1,834 & 3,679 & 3,346 & 3,179 & 3,142 & 3,099 & 3,136 & 2,785 & 2,381 & ---- \\
\hline \begin{tabular}{|l|}
$1959-60$ \\
\end{tabular} & 36,087 & 27,602 & 1,923 & 3,733 & 3,436 & 3,302 & 3,146 & 3,118 & 3,070 & 3,173 & 2,701 & ---- \\
\hline $1960-61^{5}$ & 37,260 & 28,439 & 2,000 & 3,822 & 3,502 & 3,405 & 3,278 & 3,131 & 3,095 & 3,123 & 3,083 & ---- \\
\hline \begin{tabular}{|l|}
$1961-62$ \\
\end{tabular} & 38,253 & 28,686 & 2,065 & 3,857 & 3,568 & 3,428 & 3,343 & 3,218 & 3,065 & 3,122 & 3,021 & ---- \\
\hline $1962-63^{5}$ & 39,746 & 29,374 & 2,162 & 3,928 & 3,630 & 3,518 & 3,391 & 3,332 & 3,190 & 3,140 & 3,083 & --- \\
\hline $1963-64^{5}$ & 41,025 & 29,915 & 2,177 & 4,023 & 3,705 & 3,560 & 3,467 & 3,366 & 3,299 & 3,241 & 3,077 & ---- \\
\hline $1964-65^{5}$ & 42,280 & 30,652 & 2,250 & 4,014 & 3,800 & 3,662 & 3,523 & 3,465 & 3,362 & 3,363 & 3,212 & ---- \\
\hline \begin{tabular}{|l|}
$1965-66$ \\
\end{tabular} & 42,068 & 30,466 & 2,260 & 3,915 & 3,644 & 3,595 & 3,476 & 3,377 & 3,312 & 3,297 & 3,186 & 404 \\
\hline
\end{tabular}


$<$ CG.A.3> continued

\begin{tabular}{|c|c|c|c|c|c|c|c|c|c|c|c|c|}
\hline \multirow{2}{*}{ School year } & \multirow{2}{*}{ Total } & \multicolumn{11}{|c|}{ Public Schools, kindergarten through grade 8} \\
\hline & & Total & Kindergart $^{2}$ & Grade 1 & Grade 2 & Grade 3 & Grade 4 & Grade 5 & Grade 6 & Grade 7 & Grade 8 & Ungraded $^{3}$ \\
\hline col. no. & (1) & (2) & (3) & (4) & (5) & (6) & (7) & (8) & (9) & (19) & (11) & (12) \\
\hline \begin{tabular}{|l|}
$1966-67$ \\
\end{tabular} & 43,042 & 31,162 & 2,370 & 3,954 & 3,696 & 3,615 & 3,580 & 3,463 & 3,369 & 3,409 & 3,272 & 433 \\
\hline 1967-68 & 43,890 & 31,643 & 2,420 & 3,980 & 3,723 & 3,659 & 3,580 & 3,562 & 3,450 & 3,454 & 3,357 & 459 \\
\hline $1968-69$ & 44,903 & 32,181 & 2,511 & 3,926 & 3,758 & 3,692 & 3,629 & 3,573 & 3,555 & 3,552 & 3,423 & 561 \\
\hline \begin{tabular}{|l|}
$1969-70$ \\
\end{tabular} & 45,550 & 32,513 & 2,545 & 3,869 & 3,716 & 3,720 & 3,660 & 3,621 & 3,568 & 3,667 & 3,520 & 628 \\
\hline $1970-71$ & 45,894 & 32,558 & 2,564 & 3,817 & 3,654 & 3,663 & 3,675 & 3,635 & 3,598 & 3,662 & 3,601 & 690 \\
\hline 1971-72 & 46,071 & 32,318 & 2,483 & 3,570 & 3,587 & 3,612 & 3,623 & 3,662 & 3,622 & 3,710 & 3,635 & 814 \\
\hline \begin{tabular}{|l|}
$1972-73$ \\
\end{tabular} & 45,726 & 31,879 & 2,503 & 3,352 & 3,381 & 3,533 & 3,554 & 3,597 & 3,639 & 3,713 & 3,649 & 959 \\
\hline $1973-74$ & 45,445 & 31,401 & 2,655 & 3,239 & 3,192 & 3,336 & 3,505 & 3,538 & 3,592 & 3,741 & 3,676 & 927 \\
\hline \begin{tabular}{|l|}
$1974-75$ \\
\end{tabular} & 45,073 & 30,971 & 2,801 & 3,198 & 3,106 & 3,169 & 3,345 & 3,510 & 3,559 & 3,712 & 3,708 & 863 \\
\hline \begin{tabular}{|l|}
$1975-76$ \\
\end{tabular} & 44,819 & 30,515 & 2,972 & 3,238 & 3,027 & 3,038 & 3,112 & 3,281 & 3,476 & 3,619 & 3,636 & 1,116 \\
\hline $1976-77$ & 44,311 & 29,997 & 2,918 & 3,332 & 3,086 & 2,986 & 3,025 & 3,116 & 3,298 & 3,572 & 3,578 & 1,084 \\
\hline \begin{tabular}{|l|}
$1977-78$ \\
\end{tabular} & 43,577 & 29,375 & 2,742 & 3,295 & 3,200 & 3,059 & 2,979 & 3,019 & 3,111 & 3,385 & 3,534 & 1,051 \\
\hline \begin{tabular}{|l|}
$1978-79$ \\
\end{tabular} & 42,551 & 28,463 & 2,652 & 3,062 & 3,148 & 3,158 & 3,046 & 2,980 & 3,036 & 3,228 & 3,355 & 798 \\
\hline $1979-80$ & 41,651 & 28,034 & 2,675 & 2,937 & 2,909 & 3,120 & 3,148 & 3,055 & 2,999 & 3,128 & 3,171 & 894 \\
\hline \begin{tabular}{|c|}
$1980-81$ \\
\end{tabular} & 40,877 & 27,647 & 2,689 & 2,894 & 2,800 & 2,893 & 3,107 & 3,130 & 3,038 & 3,085 & 3,086 & 924 \\
\hline $1981-82$ & 40,044 & 27,280 & 2,688 & 2,951 & 2,782 & 2,806 & 2,918 & 3,127 & 3,180 & 3,183 & 3,059 & 587 \\
\hline \begin{tabular}{|l|}
$1982-83$ \\
\end{tabular} & 39,566 & 27,161 & 2,846 & 2,937 & 2,790 & 2,763 & 2,798 & 2,912 & 3,142 & 3,288 & 3,123 & 563 \\
\hline \begin{tabular}{|l|}
$1983-84$ \\
\end{tabular} & 39,252 & 26,981 & 2,859 & 3,080 & 2,781 & 2,772 & 2,758 & 2,798 & 2,928 & 3,247 & 3,222 & 535 \\
\hline 1984-85 & 39,208 & 26,905 & 3,009 & 3,113 & 2,904 & 2,765 & 2,772 & 2,761 & 2,831 & 3,036 & 3,186 & 528 \\
\hline 1985-86 & 39,422 & 27,034 & 3,192 & 3,239 & 2,941 & 2,895 & 2,771 & 2,776 & 2,789 & 2,938 & 2,982 & 511 \\
\hline $1986-87$ & 39,753 & 27,420 & 3,310 & 3,358 & 3,054 & 2,933 & 2,896 & 2,775 & 2,806 & 2,899 & 2,870 & 520 \\
\hline 1987-88 & 40,008 & 27,933 & 3,389 & 3,407 & 3,173 & 3,046 & 2,938 & 2,901 & 2,811 & 2,910 & 2,839 & 520 \\
\hline \begin{tabular}{|l|}
$1988-89$ \\
\end{tabular} & 40,189 & 28,501 & 3,433 & 3,460 & 3,223 & 3,167 & 3,051 & 2,945 & 2,937 & 2,905 & 2,853 & 527 \\
\hline \begin{tabular}{|l|}
$1989-90$ \\
\end{tabular} & 40,543 & 29,152 & 3,487 & 3,485 & 3,289 & 3,235 & 3,182 & 3,067 & 2,987 & 3,027 & 2,853 & 540 \\
\hline \begin{tabular}{|l|}
$1990-91$ \\
\end{tabular} & 41,217 & 29,878 & 3,609 & 3,499 & 3,327 & 3,297 & 3,248 & 3,197 & 3,110 & 3,067 & 2,979 & 543 \\
\hline \begin{tabular}{|l|}
$1991-92$ \\
\end{tabular} & 42,047 & 30,506 & 3,686 & 3,556 & 3,360 & 3,334 & 3,315 & 3,268 & 3,239 & 3,181 & 3,020 & 545 \\
\hline $1992-93$ & 42,823 & 31,088 & 3,818 & 3,542 & 3,431 & 3,361 & 3,342 & 3,325 & 3,303 & 3,299 & 3,129 & 539 \\
\hline \begin{tabular}{|l|}
$1993-94$ \\
\end{tabular} & 43,465 & 31,504 & 3,922 & 3,529 & 3,429 & 3,437 & 3,361 & 3,350 & 3,356 & 3,355 & 3,249 & 515 \\
\hline \begin{tabular}{|l|}
$1994-95$ \\
\end{tabular} & 44,111 & 31,898 & 4,047 & 3,593 & 3,440 & 3,439 & 3,426 & 3,372 & 3,381 & 3,404 & 3,302 & 494 \\
\hline 1995-96 & 44,840 & 32,341 & 4,173 & 3,671 & 3,507 & 3,445 & 3,431 & 3,438 & 3,395 & 3,422 & 3,356 & 502 \\
\hline
\end{tabular}

-38 - 
$<$ CG.A.3> continued

\begin{tabular}{|c|c|c|c|c|c|c|c|}
\hline \multirow[t]{2}{*}{ School year } & \multicolumn{7}{|c|}{ Public schools, grades 9 through 12 and postgraduate } \\
\hline & Total & Grade 9 & Grade 10 & Grade 11 & Grade 12 & Ungraded $^{4}$ & $\begin{array}{c}\text { Post- } \\
\text { graduate }\end{array}$ \\
\hline Units & thousands & thousands & thousands & thousands & thousands & thousands & thousands \\
\hline col. no. & (13) & (14) & (15) & (16) & (17) & (18) & (19) \\
\hline 1910-11 & 1,157 & 495 & 309 & 208 & 145 & --- & --- \\
\hline 1911-12 & 1,201 & 501 & 325 & 219 & 156 & --- & --- \\
\hline $1912-13$ & 1,333 & 547 & 359 & 248 & 180 & ---- & --- \\
\hline 1913-14 & 1,432 & 584 & 384 & 266 & 198 & --- & --- \\
\hline 1914-15 & 1,562 & 639 & 417 & 287 & 219 & --- & --- \\
\hline 1915-16 & 1,711 & 693 & 460 & 317 & 241 & --- & ---- \\
\hline $1916-17^{5}$ & 1,795 & 743 & 476 & 324 & 251 & ---- & ---- \\
\hline 1917-18 & 1,934 & 816 & 507 & 342 & 269 & --- & --- \\
\hline $1918-19^{5}$ & 2,067 & 867 & 541 & 369 & 290 & --- & --- \\
\hline $1919-20$ & 2,200 & 917 & 576 & 396 & 312 & --- & --- \\
\hline $1920-21^{5}$ & 2,537 & 1,065 & 679 & 456 & 337 & ---- & ---- \\
\hline 1921-22 & 2,873 & 1,214 & 782 & 516 & 362 & ---- & ---- \\
\hline $1922-23^{5}$ & 3,131 & 1,271 & 851 & 583 & 426 & --- & ---- \\
\hline 1923-24 & 3,390 & 1,328 & 920 & 651 & 490 & --- & ---- \\
\hline $1924-25^{5}$ & 3,651 & 1,424 & 970 & 716 & 541 & --- & ---- \\
\hline $1925-26$ & 3,757 & 1,425 & 1,005 & 736 & 592 & --- & ---- \\
\hline $1926-27^{5}$ & 3,834 & 1,451 & 1,025 & 752 & 607 & --- & --- \\
\hline 1927-28 & 3,911 & 1,476 & 1,046 & 768 & 622 & --- & ---- \\
\hline $1928-29^{5}$ & 4,155 & 1,551 & 1,119 & 824 & 661 & --- & ---- \\
\hline 1929-30 & 4,399 & 1,627 & 1,192 & 880 & 701 & --- & ---- \\
\hline $1930-31^{5}$ & 4,770 & 1,702 & 1,290 & 973 & 786 & 18 & ---- \\
\hline 1931-32 & 5,140 & 1,778 & 1,387 & 1,067 & 872 & 37 & ---- \\
\hline \begin{tabular}{|l|}
$1932-33^{5}$ \\
\end{tabular} & 5,405 & 1,816 & 1,464 & 1,138 & 939 & 48 & ---- \\
\hline 1933-34 & 5,669 & 1,855 & 1,540 & 1,209 & 1,005 & 59 & ---- \\
\hline $1934-35^{5}$ & 5,822 & 1,913 & 1,580 & 1,229 & 1,035 & 65 & ---- \\
\hline \begin{tabular}{|l|}
$1935-36$ \\
\end{tabular} & 5,975 & 1,970 & 1,620 & 1,249 & 1,064 & 71 & ---- \\
\hline $1936-37^{5}$ & 6,101 & 1,975 & 1,645 & 1,314 & 1,107 & 60 & ---- \\
\hline \begin{tabular}{|l|}
$1937-38$ \\
\end{tabular} & 6,227 & 1,979 & 1,669 & 1,379 & 1,151 & 48 & ---- \\
\hline \begin{tabular}{|c|}
$1938-39^{5}$ \\
\end{tabular} & 6,414 & 1,995 & 1,718 & 1,433 & 1,216 & 52 & ---- \\
\hline $1939-40$ & 6,601 & 2,011 & 1,767 & 1,486 & 1,282 & 55 & ---- \\
\hline $1940-41^{5}$ & 6,714 & 2,034 & 1,793 & 1,517 & 1,323 & 47 & ---- \\
\hline 1941-42 & 6,388 & 1,927 & 1,706 & 1,451 & 1,273 & 31 & ---- \\
\hline $1942-43^{5}$ & 6,122 & 1,898 & 1,654 & 1,374 & 1,170 & 26 & ---- \\
\hline 1943-44 & 5,554 & 1,775 & 1,520 & 1,230 & 1,010 & 20 & ---- \\
\hline $1944-45^{5}$ & 5,560 & 1,743 & 1,530 & 1,237 & 1,016 & 35 & ---- \\
\hline $1945-46$ & 5,622 & 1,728 & 1,555 & 1,256 & 1,032 & 50 & ---- \\
\hline $1946-47^{5}$ & 5,838 & 1,761 & 1,583 & 1,309 & 1,120 & 65 & ---- \\
\hline \begin{tabular}{|l|}
$1947-48$ \\
\end{tabular} & 5,653 & 1,673 & 1,503 & 1,272 & 1,131 & 75 & ---- \\
\hline $1948-49^{5}$ & 5,658 & 1,709 & 1,499 & 1,267 & 1,126 & 57 & ---- \\
\hline $1949-50$ & 5,725 & 1,761 & 1,513 & 1,275 & 1,134 & 42 & ---- \\
\hline $1950-51^{5}$ & 5,806 & 1,781 & 1,548 & 1,313 & 1,128 & 37 & ---- \\
\hline \begin{tabular}{|l|}
$1951-52$ \\
\end{tabular} & 5,882 & 1,820 & 1,582 & 1,338 & 1,111 & 31 & ---- \\
\hline
\end{tabular}




\begin{tabular}{|c|c|c|c|c|c|c|c|}
\hline \multirow[t]{2}{*}{ School year } & \multicolumn{7}{|c|}{ Public schools, grades 9 through 12 and postgraduate } \\
\hline & Total & Grade 9 & Grade 10 & Grade 11 & Grade 12 & Ungraded $^{4}$ & $\begin{array}{c}\text { Post- } \\
\text { graduate }\end{array}$ \\
\hline Units & thousands & thousands & thousands & thousands & thousands & thousands & thousands \\
\hline col. no. & (13) & (14) & (15) & (16) & (17) & (18) & (19) \\
\hline $1953-54$ & 6,290 & 1,944 & 1,717 & 1,412 & 1,190 & 27 & $\begin{array}{ll}--- \\
\end{array}$ \\
\hline $1954-55^{5}$ & 6,574 & 2,028 & 1,765 & 1,520 & 1,246 & 15 & ---- \\
\hline \begin{tabular}{|l|}
$1955-56$ \\
\end{tabular} & 6,873 & 2,143 & 1,849 & 1,543 & 1,326 & 13 & ---- \\
\hline 1956-57 & 7,318 & 2,368 & 1,974 & 1,615 & 1,349 & 13 & ---- \\
\hline $1957-58$ & 7,860 & 2,480 & 2,194 & 1,736 & 1,431 & 19 & ---- \\
\hline 1958-59 & 8,258 & 2,412 & 2,318 & 1,955 & 1,538 & 35 & ---- \\
\hline $1959-60$ & 8,485 & 2,412 & 2,258 & 2,063 & 1,747 & 4 & ---- \\
\hline $1960-61^{5}$ & 8,821 & 2,750 & 2,252 & 1,997 & 1,820 & 2 & ---- \\
\hline 1961-62 & 9,566 & 3,156 & 2,595 & 2,018 & 1,791 & 7 & ---- \\
\hline $1962-63^{5}$ & $10,372^{6}$ & 3,172 & 2,981 & 2,348 & 1,866 & 5 & ---- \\
\hline $1963-64^{5}$ & $11,110^{6}$ & 3,190 & 3,006 & 2,747 & 2,160 & 6 & ---- \\
\hline $1964-65^{5}$ & $11,628^{6}$ & 3,198 & 3,085 & 2,778 & 2,560 & 7 & ---- \\
\hline 1965-66 & $11,602^{6}$ & 3,215 & 2,993 & 2,741 & 2,477 & 7 & 169 \\
\hline $1966-67$ & $11,880^{6}$ & 3,318 & 3,111 & 2,756 & 2,508 & 8 & 179 \\
\hline $1967-68$ & 12,247 & 3,395 & 3,221 & 2,879 & 2,525 & 16 & 210 \\
\hline 1968-69 & 12,723 & 3,508 & 3,310 & 2,986 & 2,650 & 17 & 251 \\
\hline 1969-70 & 13,037 & 3,568 & 3,405 & 3,047 & 2,732 & 21 & 264 \\
\hline $1970-71$ & 13,336 & 3,654 & 3,458 & 3,128 & 2,775 & 28 & 293 \\
\hline \begin{tabular}{|l|}
$1971-72$ \\
\end{tabular} & 13,753 & 3,781 & 3,571 & 3,200 & 2,864 & 9 & 328 \\
\hline $1972-73$ & 13,848 & 3,779 & 3,648 & 3,248 & 2,873 & 10 & 290 \\
\hline 1973-74 & 14,044 & 3,801 & 3,650 & 3,323 & 2,918 & 4 & 348 \\
\hline 1974-75 & 14,103 & 3,832 & 3,675 & 3,302 & 2,955 & 13 & 326 \\
\hline 1975-76 & 14,304 & 3,879 & 3,723 & 3,354 & 2,986 & 23 & 339 \\
\hline 1976-77 & 14,314 & 3,825 & 3,738 & 3,373 & 3,015 & 23 & 340 \\
\hline 1977-78 & 14,203 & 3,779 & 3,686 & 3,388 & 3,026 & 13 & 311 \\
\hline $1978-79$ & 14,088 & 3,726 & 3,610 & 3,312 & 3,023 & (NA) & 416 \\
\hline $1979-80$ & 13,616 & 3,526 & 3,532 & 3,241 & 2,969 & (NA) & 348 \\
\hline $1980-81$ & 13,231 & 3,377 & 3,368 & 3,195 & 2,925 & (NA) & 366 \\
\hline 1981-82 & 12,764 & 3,286 & 3,218 & 3,039 & 2,907 & (NA) & 314 \\
\hline $1982-83$ & 12,405 & 3,248 & 3,137 & 2,917 & 2,787 & (NA) & 315 \\
\hline $1983-84$ & 12,271 & 3,330 & 3,103 & 2,861 & 2,678 & (NA) & 299 \\
\hline 1984-85 & 12,304 & 3,440 & 3,145 & 2,819 & 2,599 & (NA) & 300 \\
\hline $1985-86$ & 12,388 & 3,439 & 3,230 & 2,866 & 2,550 & (NA) & 303 \\
\hline $1986-87$ & 12,333 & 3,256 & 3,215 & 2,954 & 2,601 & (NA) & 308 \\
\hline $1987-88$ & 12,076 & 3,143 & 3,020 & 2,936 & 2,681 & (NA) & 296 \\
\hline 1988-89 & 11,687 & 3,106 & 2,895 & 2,749 & 2,650 & (NA) & 288 \\
\hline 1989-90 & 11,390 & 3,141 & 2,868 & 2,629 & 2,473 & (NA) & 279 \\
\hline 1990-91 & 11,338 & 3,169 & 2,896 & 2,612 & 2,381 & (NA) & 282 \\
\hline 1991-92 & 11,541 & 3,313 & 2,915 & 2,645 & 2,392 & (NA) & 275 \\
\hline $1992-93$ & 11,735 & 3,352 & 3,027 & 2,656 & 2,431 & (NA) & 269 \\
\hline 1993-94 & 11,961 & 3,487 & 3,050 & 2,751 & 2,424 & (NA) & 248 \\
\hline 1994-95 & 12,213 & 3,604 & 3,131 & 2,748 & 2,488 & (NA) & 242 \\
\hline 1995-96 & 12,500 & 3,704 & 3,237 & 2,826 & 2,487 & (NA) & 245 \\
\hline
\end{tabular}

$-40-$ 
Sources: <CG.A.3.1> to <CG.A.3.19>, 1910-11 to 1980-81, U.S. Department of Education, 120 Years of American Education: A Statistical Portrait (Washington, D.C.: U.S. G.P.O., 1993), table 10. The underlying sources are U.S. Office of Education, Annual Report of the Commissioner of Education, U.S. Office of Education, Biennial Survey of Education in the United States, and U.S. Department of Education, Digest of Education Statistics, annual issues (Washington, D.C.: U.S. G.P.O.). 1981-82 to 1995-96, Digest of Education Statistics 1997, table 43.

The proportion of eighth graders continuing to ninth grade is often too large, and the proportion of seventh graders continuing to eighth grade is often too small, in these data. For example, the proportion of continuing from eighth to ninth grade is above one for most cohorts entering fifth grade since 1925, whereas the proportion continuing from seventh to eighth grade for cohorts entering fifth grade from 1925 to the early 1940s is distinctly too low. On average, however, the proportion continuing from seventh to ninth grade appears reasonable in comparison with the other transition statistics. There are several possible reasons. The number of ninth graders in public schools may be inflated, compared with the number of eighth graders, because many pupils in private schools transfer to public schools for high school. The discrepancies, however, may also be due to the misclassification of eighth graders as secondary school pupils.

Footnotes:

11: Enrollment data prior to 1965 include students who enrolled at any time during the school year. After 1965, enrollment data include only those students who enrolled at the beginning of the year.

12: In later years, data contain a relatively small number of prekindergarten students.

13: Ungraded enrollment includes those children enrolled in schools or special programs that do not differentiate by grade level. Prior to fall 1965, enrollment in ungraded and special classes was prorated among the regular grades.

14: Postgraduate students include those who have finished their requirements for a diploma but are taking classes at a secondary school.

15: Estimated.

16: These data are not identical to those in the underlying sources because of the inclusion of seventh and eighth grade enrollments in the secondary school data for several states. 
<CG.A.4> School enrollment and school enrollment rates, by age and sex: 1940 to $1995^{1}$

\begin{tabular}{|c|c|c|c|c|c|c|c|c|c|c|c|c|c|c|}
\hline \multirow{3}{*}{ Year } & \multicolumn{14}{|c|}{ School enrollment and enrollment rates of males and females, by age } \\
\hline & \multicolumn{2}{|c|}{ Total, 5 to 34} & \multicolumn{2}{|c|}{5 and 6} & \multicolumn{2}{|c|}{7 to 13} & \multicolumn{2}{|c|}{14 to 17} & \multicolumn{2}{|c|}{18 and 19} & \multicolumn{2}{|c|}{20 to 24} & \multicolumn{2}{|c|}{25 to 34} \\
\hline & number & rate & number & rate & number & rate & number & rate & number & rate & number & rate & number & rate \\
\hline HS no. & H442 & H442 & H443 & H443 & $\mathrm{H} 444$ & H444 & H445 & H445 & H446 & H446 & H447 & H447 & H448 & H448 \\
\hline Units & 000 & $\%$ & 000 & $\%$ & 000 & $\%$ & 000 & $\%$ & 000 & $\%$ & 000 & $\%$ & 000 & $\%$ \\
\hline col. no. & (1) & (2) & (3) & (4) & (5) & (6) & (7) & (8) & (9) & (10) & (11) & (12) & (13) & (14) \\
\hline $1940^{2}$ & $26,759^{3}$ & 57.7 & 1,805 & 43.0 & 15,035 & 95.0 & 7,709 & 79.3 & 1,449 & 28.9 & 761 & 6.6 & --- & --- \\
\hline 1945 & $25,515^{3}$ & 64.0 & 2,833 & 60.4 & 14,747 & 98.1 & 6,956 & 78.4 & 668 & 20.7 & 311 & 3.9 & --- & --- \\
\hline 1946 & $26,924^{3}$ & 61.1 & 3,030 & 62.0 & 14,966 & 98.3 & 6,900 & 79.6 & 884 & 22.5 & 1,144 & 10.1 & --- & --- \\
\hline 1947 & 27,746 & 41.1 & 3,069 & 58.0 & 15,302 & 98.5 & 6,737 & 79.3 & 1,007 & 24.3 & 1,183 & 10.2 & 448 & 2.0 \\
\hline 1948 & 28,390 & 41.5 & 3,237 & 56.0 & 15,688 & 98.1 & 6,824 & 81.8 & 1,134 & 26.9 & 1,103 & 9.7 & 405 & 1.8 \\
\hline 1949 & 29,283 & 42.4 & 3,487 & 59.3 & 16,374 & 98.6 & 6,778 & 81.6 & 1,028 & 25.3 & 1,041 & 9.2 & 576 & 2.5 \\
\hline 1950 & $30,073^{4}$ & 51.6 & 3,304 & 58.2 & 17,222 & 98.7 & 6,988 & 83.4 & 1,199 & 29.7 & 1,001 & 9.2 & $360^{5}$ & 3.0 \\
\hline 1951 & $30,466^{4}$ & 52.8 & 3,196 & 54.5 & 17,946 & 99.1 & 7,216 & 85.2 & 974 & 26.2 & 846 & 8.6 & $288^{5}$ & 2.5 \\
\hline 1952 & 31,980 & 45.4 & 3,732 & 54.7 & 18,414 & 98.8 & 7,440 & 85.2 & 1,062 & 28.8 & 904 & 9.7 & 428 & 1.8 \\
\hline 1953 & 32,796 & 46.4 & 4,038 & 55.7 & 18,525 & 99.4 & 7,538 & 85.9 & 1,180 & 31.2 & 981 & 11.1 & 534 & 2.3 \\
\hline 1954 & 36,083 & 50.0 & 5,443 & 77.3 & 19,952 & 99.4 & 7,784 & 87.1 & 1,268 & 32.4 & 999 & 11.2 & 635 & 2.7 \\
\hline 1955 & 37,426 & 50.8 & 5,520 & 78.1 & 21,028 & 99.2 & 7,970 & 86.9 & 1,232 & 31.5 & 1,010 & 11.1 & 667 & 2.9 \\
\hline 1956 & 39,353 & 52.3 & 5,597 & 77.6 & 21,946 & 99.3 & 8,413 & 88.2 & 1,407 & 35.4 & 1,192 & 12.8 & 798 & 3.5 \\
\hline 1957 & 41,166 & 53.6 & 5,829 & 78.6 & 22,705 & 99.5 & 9,067 & 89.5 & 1,409 & 34.9 & 1,336 & 14.0 & 820 & 3.6 \\
\hline 1958 & 42,900 & 54.8 & 6,101 & 80.4 & 23,623 & 99.5 & 9,446 & 89.2 & 1,564 & 37.6 & 1,307 & 13.4 & 858 & $\begin{array}{l}3.8 \\
\end{array}$ \\
\hline 1959 & 44,370 & 55.5 & 6,222 & 80.0 & 24,626 & 99.4 & 9,839 & 90.2 & 1,601 & 36.8 & 1,283 & 12.7 & 799 & 3.8 \\
\hline 1960 & 46,259 & \begin{tabular}{l|}
56.4 \\
\end{tabular} & 6,438 & 80.7 & 25,621 & 99.5 & 10,240 & 90.3 & 1,817 & 38.4 & 1,350 & 13.1 & 792 & 3.6 \\
\hline 1961 & 47,708 & 56.8 & 6,638 & 81.7 & 25,801 & 99.3 & 11,163 & 91.4 & 1,952 & 38.0 & 1,468 & 13.7 & \begin{tabular}{l|l}
686 \\
\end{tabular} & 3.2 \\
\hline 1962 & 48,704 & 57.8 & 6,651 & 82.2 & 25,634 & 99.3 & 11,740 & 92.0 & 2,144 & 41.8 & 1,725 & 15.6 & 810 & 3.8 \\
\hline 1963 & 50,356 & 58.5 & 6,768 & 82.7 & 26,203 & 99.3 & 12,517 & 92.9 & 2,061 & 40.9 & 2,014 & 17.3 & 793 & 3.7 \\
\hline 1964 & 51,660 & $\begin{array}{l}58.7 \\
\end{array}$ & 6,842 & 83.3 & 26,725 & 99.0 & 13,014 & 93.1 & 2,196 & 41.6 & 2,048 & 16.8 & 835 & 3.9 \\
\hline 1965 & 53,769 & 59.7 & 6,995 & 84.4 & 27,450 & 99.4 & 13,033 & 93.2 & 2,930 & 46.3 & 2,360 & 19.0 & 1,001 & 4.7 \\
\hline 1966 & 55,070 & 60.0 & 7,156 & 85.1 & 27,895 & 99.3 & 13,293 & 93.7 & 3,176 & 47.2 & 2,547 & 19.9 & 1,003 & 4.6 \\
\hline 1967 & 56,511 & \begin{tabular}{l|}
60.2 \\
\end{tabular} & 7,352 & 87.4 & 28,286 & 99.3 & 13,638 & 93.7 & 3,026 & 47.6 & 3,002 & 22.0 & \begin{tabular}{l|l|}
1,207 \\
\end{tabular} & 5.4 \\
\hline 1968 & 57,564 & 60.1 & 7,241 & 87.6 & 28,620 & 99.1 & 14,118 & 94.2 & 3,317 & 50.4 & 2,988 & 21.4 & 1,280 & 5.5 \\
\hline 1969 & 58,718 & 60.1 & 7,155 & 88.4 & 28,844 & 99.1 & 14,452 & 94.0 & 3,351 & 50.2 & 3,380 & 23.0 & \begin{tabular}{l|}
1,536 \\
\end{tabular} & 6.4 \\
\hline
\end{tabular}


<CG.A.4> continued

\begin{tabular}{|c|c|c|c|c|c|c|c|c|c|c|c|c|c|c|}
\hline \multirow{3}{*}{ Year } & \multicolumn{14}{|c|}{ School enrollment and enrollment rates of males and females, by age } \\
\hline & \multicolumn{2}{|c|}{ Total, 5 to 34} & \multicolumn{2}{|c|}{5 and 6} & \multicolumn{2}{|c|}{7 to 13} & \multicolumn{2}{|c|}{14 to 17} & \multicolumn{2}{|c|}{18 and 19} & \multicolumn{2}{|c|}{20 to 24} & \multicolumn{2}{|c|}{25 to 34} \\
\hline & number & rate & number & rate & number & rate & number & rate & number & rate & number & rate & number & rate \\
\hline Units & 000 & $\%$ & 000 & $\%$ & 000 & $\%$ & 000 & $\%$ & 000 & $\%$ & 000 & $\%$ & 000 & $\%$ \\
\hline col. no. & (1) & (2) & (3) & (4) & (5) & (6) & (7) & (8) & (9) & (10) & (11) & (12) & (13) & (14) \\
\hline 1970 & 58,896 & 59.0 & 7,000 & 89.5 & 28,943 & 99.2 & 14,796 & 94.1 & 3,322 & 47.7 & 3,359 & 21.5 & 1,477 & 6.0 \\
\hline 1971 & 59,630 & 58.6 & 6,818 & 91.6 & 28,823 & 99.1 & 15,144 & 94.5 & 3,557 & 49.2 & 3,606 & 21.9 & 1,682 & 6.6 \\
\hline 1972 & 58,486 & 56.9 & 6,340 & 91.9 & 27,907 & 99.2 & 15,267 & 93.3 & 3,458 & 46.3 & 3,692 & 21.6 & \begin{tabular}{|l|}
1,822 \\
\end{tabular} & 6.8 \\
\hline 1973 & 57,703 & 55.4 & 6,228 & 92.5 & 27,289 & 99.2 & 15,354 & 92.9 & 3,284 & 42.9 & 3,659 & 20.8 & 1,889 & 6.7 \\
\hline 1974 & 58,252 & 55.3 & 6,421 & 94.2 & 26,833 & 99.3 & 15,529 & 92.9 & 3,375 & 43.1 & 3,816 & 21.4 & 2,278 & 7.8 \\
\hline 1975 & 58,867 & 55.1 & 6,590 & 94.7 & 26,104 & 99.3 & 15,698 & 93.6 & 3,765 & 46.9 & 4,121 & 22.4 & 2,589 & 8.5 \\
\hline 1976 & 58,533 & 54.3 & 6,701 & 95.6 & 25,455 & 99.2 & 15,649 & 93.7 & 3,768 & 46.2 & 4,379 & 23.3 & 2,581 & 8.2 \\
\hline 1977 & 58,078 & 53.6 & 6,433 & 95.8 & 25,052 & 99.4 & 15,529 & 93.6 & 3,762 & 46.2 & 4,390 & 22.9 & 2,912 & 9.0 \\
\hline 1978 & 56,544 & 52.2 & 5,997 & 95.3 & 24,597 & 99.1 & 15,356 & 93.7 & 3,700 & 45.4 & 4,245 & 21.8 & 2,649 & 8.0 \\
\hline 1979 & 55,717 & 51.2 & 5,846 & 95.8 & 24,145 & 99.2 & 14,970 & 93.6 & 3,693 & 45.0 & 4,290 & 21.7 & 2,773 & 8.1 \\
\hline 1980 & 55,068 & 50.4 & 5,853 & 95.7 & 23,751 & 99.3 & 14,411 & 93.4 & 3,788 & 46.4 & 4,446 & 22.3 & 2,819 & 7.9 \\
\hline 1981 & 56,057 & 49.7 & 5,955 & 94.0 & 24,025 & 99.2 & 14,373 & 94.1 & 3,976 & 49.0 & 4,700 & 22.5 & 3,028 & 8.0 \\
\hline 1982 & 55,483 & 49.3 & 6,070 & 95.0 & 23,654 & 99.0 & 13,928 & 94.4 & 3,837 & 47.8 & 4,897 & 23.5 & 3,097 & 8.0 \\
\hline 1983 & 55,120 & 49.0 & 6,214 & 95.5 & 23,278 & 99.2 & 13,791 & 95.0 & 3,938 & 50.4 & 4,720 & 22.7 & 3,179 & 8.1 \\
\hline 1984 & 54,704 & 48.6 & 6,332 & 94.5 & 22,854 & 99.2 & 13,793 & 94.7 & 3,724 & 50.1 & 4,886 & 23.7 & 3,115 & 7.7 \\
\hline 1985 & 55,214 & 48.9 & 6,697 & 96.1 & 22,849 & 99.2 & 14,016 & 94.9 & 3,716 & 51.6 & 4,776 & 24.0 & 3,160 & 7.7 \\
\hline 1986 & 55,340 & 48.8 & 6,917 & 95.3 & 22,987 & 99.2 & 13,868 & 94.9 & 3,872 & 54.6 & 4,584 & 23.6 & 3,112 & 7.4 \\
\hline 1987 & 55,943 & 49.3 & 6,956 & 95.2 & 23,521 & 99.5 & 13,532 & 95.0 & 3,982 & 55.6 & 4,792 & 25.5 & 3,160 & 7.5 \\
\hline 1988 & 56,049 & 49.3 & 7,044 & 96.0 & 24,044 & 99.7 & 13,042 & 95.1 & 4,059 & 55.6 & 4,816 & 26.1 & 3,044 & 7.1 \\
\hline 1989 & 56,338 & 49.7 & 6,990 & 95.2 & 24,431 & 99.3 & 12,747 & 95.7 & 4,125 & 56.0 & 4,837 & 27.0 & 3,208 & 7.5 \\
\hline 1990 & 57,297 & 50.6 & 7,207 & 96.5 & 25,016 & 99.6 & 12,653 & 95.8 & 4,044 & 57.2 & 5,083 & 28.6 & 3,294 & 7.7 \\
\hline 1991 & 58,208 & 51.4 & 7,178 & 95.4 & 25,445 & 99.6 & 12,789 & 96.0 & 3,969 & 59.6 & 5,406 & 30.2 & 3,422 & 8.1 \\
\hline 1992 & 59,021 & 52.2 & 7,252 & 95.5 & 25,768 & 99.4 & 13,133 & 96.7 & 4,012 & 61.4 & 5,604 & 31.6 & 3,251 & 7.8 \\
\hline 1993 & 59,455 & 52.6 & 7,298 & 95.4 & 26,110 & 99.5 & 13,350 & 96.5 & 4,063 & 61.6 & 5,389 & 30.8 & 3,245 & 7.9 \\
\hline 1994 & 62,510 & 53.8 & 7,752 & 96.7 & 26,768 & 99.3 & 14,414 & 96.6 & 4,180 & 60.2 & 5,857 & 32.0 & 3,538 & 8.6 \\
\hline 1995 & 62,897 & 54.1 & 7,901 & 96.0 & 27,003 & 98.9 & 14,648 & 96.3 & 4,274 & 59.4 & 5,570 & 31.5 & 3,500 & 8.6 \\
\hline
\end{tabular}


<CG.A.4> continued

\begin{tabular}{|c|c|c|c|c|c|c|c|c|c|c|c|c|c|c|}
\hline \multirow{3}{*}{ Year } & \multicolumn{14}{|c|}{ School enrollment and enrollment rates of males, by age } \\
\hline & \multicolumn{2}{|c|}{ Total, 5 to 34} & \multicolumn{2}{|c|}{5 and 6} & \multicolumn{2}{|c|}{7 to 13} & \multicolumn{2}{|c|}{14 to 17} & \multicolumn{2}{|c|}{18 and 19} & \multicolumn{2}{|c|}{20 to 24} & \multicolumn{2}{|c|}{25 to 34} \\
\hline & number & rate & number & rate & number & rate & number & rate & number & rate & number & rate & number & rate \\
\hline HS no. & H442 & H442 & H443 & H443 & H444 & H444 & H445 & H445 & $H 446$ & $H 446$ & $H 447$ & $H 447$ & $H 448$ & $H 448$ \\
\hline Units & 000 & $\%$ & 000 & $\%$ & 000 & $\%$ & 000 & $\%$ & 000 & $\%$ & 000 & $\%$ & 000 & $\%$ \\
\hline col. no. & (1) & (2) & (3) & (4) & (5) & (6) & (7) & (8) & (9) & (10) & (11) & (12) & (13) & (14) \\
\hline $1940^{2}$ & 13,615 & 58.6 & 901 & 42.3 & 7,607 & 94.8 & 3,870 & 78.9 & 770 & 30.8 & 467 & 8.2 & --- & --- \\
\hline 1945 & 12,660 & 72.7 & 1,423 & 59.6 & 7,456 & 97.7 & 3,475 & 78.0 & 192 & 21.6 & 114 & 5.6 & --- & --- \\
\hline 1946 & 13,941 & 64.9 & 1,514 & 60.8 & 7,585 & 98.0 & 3,435 & 79.2 & 469 & 29.0 & 938 & 17.7 & --- & -- \\
\hline 1947 & 14,635 & 44.3 & 1,549 & 57.4 & 7,781 & 98.6 & 3,364 & 78.9 & 587 & 31.4 & 947 & 17.0 & 407 & 3.8 \\
\hline 1948 & 14,991 & 44.8 & 1,628 & 55.1 & 7,990 & 98.3 & 3,436 & 81.9 & 682 & 34.3 & 898 & 16.5 & 358 & 3.3 \\
\hline 1949 & 15,489 & 45.8 & 1,807 & 60.2 & 8,330 & 98.5 & 3,447 & 82.5 & 593 & 31.6 & 827 & 15.4 & 487 & 4.5 \\
\hline 1950 & 15,736 & 54.8 & 1,649 & 56.8 & 8,773 & 98.7 & 3,568 & 84.4 & 680 & 35.7 & 733 & 14.3 & 333 & 5.9 \\
\hline 1951 & 15,774 & 56.8 & 1,648 & 55.1 & 9,148 & 99.1 & 3,614 & 85.2 & 534 & 32.4 & 602 & 14.3 & 228 & 4.2 \\
\hline 1952 & 16,644 & 49.4 & 1,912 & 54.8 & 9,382 & 98.7 & 3,758 & 85.4 & 612 & 37.2 & 630 & 16.9 & 350 & 3.2 \\
\hline 1953 & 16,974 & 50.2 & 2,035 & 55.0 & 9,405 & 99.2 & 3,844 & 86.8 & 642 & 37.7 & 636 & 18.5 & 414 & 3.7 \\
\hline 1954 & 18,759 & 54.0 & 2,746 & 76.3 & 10,138 & 99.2 & 4,002 & 88.7 & 730 & 40.6 & 677 & 19.1 & 465 & 4.2 \\
\hline 1955 & 19,573 & 54.9 & 2,821 & 78.1 & 10,725 & 99.2 & 4,096 & 88.6 & 752 & 42.5 & 686 & 18.1 & 494 & 4.5 \\
\hline 1956 & 20,522 & 56.3 & 2,839 & 77.1 & 11,179 & 99.1 & 4,275 & 89.1 & 809 & 45.1 & 830 & 20.6 & 620 & 5.7 \\
\hline 1957 & 21,509 & 57.5 & 2,963 & 78.3 & 11,584 & 99.5 & 4,646 & 91.1 & 780 & 43.3 & 897 & 21.3 & 639 & 5.9 \\
\hline 1958 & 22,497 & 58.7 & 3,123 & 80.6 & 12,059 & 99.5 & 4,854 & 90.7 & 898 & 47.5 & 915 & 21.0 & 648 & 6.0 \\
\hline 1959 & 23,192 & 59.1 & 3,158 & 79.5 & 12,556 & 99.3 & 5,041 & 91.4 & 918 & 45.6 & 892 & 19.6 & 627 & 5.9 \\
\hline 1960 & 24,234 & 60.0 & 3,292 & 80.8 & 13,074 & 99.5 & 5,247 & 91.3 & 1,063 & 47.8 & 936 & 19.9 & 621 & 5.9 \\
\hline 1961 & 24,944 & 60.4 & 3,402 & 82.0 & 13,167 & 99.3 & 5,705 & 92.2 & 1,170 & 48.6 & 989 & 20.2 & 511 & 4.9 \\
\hline 1962 & 25,452 & 61.7 & 3,399 & 82.6 & 13,003 & 99.2 & 6,032 & 93.7 & 1,212 & 51.2 & 1,177 & 23.4 & 629 & 6.2 \\
\hline 1963 & 26,243 & 62.3 & 3,440 & 82.7 & 13,280 & 99.1 & 6,402 & 94.2 & 1,180 & 51.0 & 1,365 & 25.6 & 576 & 5.7 \\
\hline 1964 & 26,851 & 62.3 & 3,478 & 83.4 & 13,548 & 98.8 & 6,658 & 94.4 & 1,238 & 50.9 & 1,332 & 23.8 & 597 & 5.9 \\
\hline 1965 & 28,059 & 63.5 & 3,555 & 84.4 & 13,932 & 99.3 & 6,613 & 93.6 & 1,689 & 55.6 & 1,559 & 27.6 & 711 & 7.0 \\
\hline 1966 & 28,733 & 64.1 & 3,619 & 84.5 & 14,139 & 99.2 & 6,770 & 94.4 & 1,841 & 57.8 & 1,667 & 29.2 & 697 & 6.8 \\
\hline 1967 & 29,368 & 64.1 & 3,719 & 86.6 & 14,342 & 99.1 & 6,975 & 94.7 & 1,637 & 56.3 & 1,862 & 30.6 & 832 & 7.8 \\
\hline 1968 & 30,051 & 64.3 & 3,683 & 87.3 & 14,513 & 98.9 & 7,199 & 95.0 & 1,892 & 60.4 & 1,867 & 30.5 & 897 & 8.1 \\
\hline 1969 & 30,583 & 64.1 & 3,623 & 87.7 & 14,620 & 98.9 & 7,374 & 95.0 & 1,886 & 59.4 & 2,070 & 32.0 & 1,011 & 8.9 \\
\hline
\end{tabular}


<CG.A.4> continued

\begin{tabular}{|c|c|c|c|c|c|c|c|c|c|c|c|c|c|c|}
\hline \multirow{3}{*}{ Year } & \multicolumn{14}{|c|}{ School enrollment and enrollment rates of males, by age (continued) } \\
\hline & \multicolumn{2}{|c|}{ Total, 5 to 34} & \multicolumn{2}{|c|}{5 and 6} & \multicolumn{2}{|c|}{7 to 13} & \multicolumn{2}{|c|}{14 to 17} & \multicolumn{2}{|c|}{18 and 19} & \multicolumn{2}{|c|}{20 to 24} & \multicolumn{2}{|c|}{25 to 34} \\
\hline & number & rate & number & rate & number & rate & number & rate & number & rate & number & rate & number & rate \\
\hline Units & 000 & $\%$ & 000 & $\%$ & 000 & $\%$ & 000 & $\%$ & 000 & $\%$ & 000 & $\%$ & 000 & $\%$ \\
\hline col. no. & (1) & (2) & (3) & (4) & (5) & (6) & (7) & (8) & (9) & (10) & (11) & (12) & (13) & (14) \\
\hline 1970 & 30,642 & 62.6 & 3,545 & 88.9 & 14,688 & 99.0 & 7,531 & 94.8 & 1,821 & 54.4 & 2,062 & 29.3 & 996 & 8.4 \\
\hline 1971 & 31,114 & 62.1 & 3,450 & 90.9 & 14,633 & 98.9 & 7,720 & 95.3 & 1,939 & 55.4 & 2,217 & 29.2 & 1,155 & 9.4 \\
\hline 1972 & 30,505 & 60.1 & 3,220 & 91.7 & 14,195 & 99.1 & 7,795 & 94.0 & 1,857 & 51.2 & 2,243 & 27.8 & 1,195 & 9.2 \\
\hline 1973 & 30,012 & 58.3 & 3,162 & 92.2 & 13,884 & 99.2 & 7,845 & 93.7 & 1,783 & 47.9 & 2,118 & 25.2 & 1,220 & 9.0 \\
\hline 1974 & 30,178 & 57.9 & 3,280 & 94.4 & 13,650 & 99.2 & 7,906 & 93.3 & 1,731 & 45.8 & 2,202 & 25.8 & 1,409 & 10.0 \\
\hline 1975 & 30,502 & 57.7 & 3,346 & 94.4 & 13,267 & 99.0 & 8,042 & 94.6 & 1,940 & 49.9 & 2,334 & 26.4 & 1,573 & 10.7 \\
\hline 1976 & 30,209 & 56.6 & 3,422 & 95.6 & 12,951 & 99.0 & 8,014 & 94.6 & 1,907 & 48.2 & 2,358 & 26.0 & 1,557 & 10.2 \\
\hline 1977 & 29,831 & 55.6 & 3,246 & 94.7 & 12,751 & 99.3 & 7,934 & 94.3 & 1,919 & 48.4 & 2,401 & 25.9 & 1,580 & 10.0 \\
\hline 1978 & 29,002 & 54.0 & 3,054 & 95.1 & 12,514 & 99.0 & 7,814 & 93.9 & 1,902 & 47.8 & 2,290 & 24.3 & 1,428 & 8.8 \\
\hline 1979 & 28,459 & 52.8 & 3,003 & 96.3 & 12,285 & 99.0 & 7,680 & 94.5 & 1,874 & 46.6 & 2,229 & 23.3 & 1,388 & 8.3 \\
\hline 1980 & 27,952 & 51.6 & 2,971 & 95.0 & 12,110 & 99.2 & 7,321 & 93.7 & 1,879 & 47.1 & 2,299 & 23.8 & 1,372 & 7.9 \\
\hline 1981 & 28,577 & 51.0 & 3,051 & 94.2 & 12,253 & 99.1 & 7,309 & 94.3 & 2,018 & 50.5 & 2,467 & 24.4 & 1,479 & 8.0 \\
\hline 1982 & 28,255 & 50.5 & 3,093 & 94.7 & 12,075 & 99.1 & 7,108 & 94.9 & 1,937 & 48.9 & 2,534 & 25.0 & 1,508 & 8.0 \\
\hline 1983 & 28,230 & 50.4 & 3,166 & 95.1 & 11,887 & 99.1 & 7,021 & 95.1 & 1,956 & 50.5 & 2,582 & 25.5 & 1,618 & 8.4 \\
\hline 1984 & 28,013 & 50.0 & 3,220 & 94.0 & 11,665 & 99.1 & 7,018 & 94.7 & 1,924 & 52.4 & 2,651 & 26.3 & 1,535 & 7.8 \\
\hline 1985 & 28,087 & 50.1 & 3,422 & 95.3 & 11,666 & 99.2 & 7,186 & 95.4 & 1,852 & 52.2 & 2,467 & 25.6 & 1,494 & 7.5 \\
\hline 1986 & 28,262 & 50.0 & 3,544 & 96.0 & 11,768 & 99.1 & 7,095 & 94.9 & 1,998 & 57.1 & 2,305 & 24.5 & 1,552 & 7.5 \\
\hline 1987 & 28,547 & 50.5 & 3,580 & 95.7 & 12,057 & 99.7 & 6,928 & 95.3 & 2,047 & 57.9 & 2,469 & 27.2 & 1,466 & 7.0 \\
\hline 1988 & 28,483 & 50.4 & 3,573 & 95.9 & 12,329 & 99.7 & 6,679 & 95.4 & 2,032 & 56.2 & 2,448 & 27.6 & 1,422 & 6.8 \\
\hline 1989 & 28,539 & 50.4 & 3,551 & 95.1 & 12,509 & 99.2 & 6,583 & 96.1 & 2,061 & 56.6 & 2,339 & 26.9 & 1,496 & 7.1 \\
\hline 1990 & 29,077 & 51.4 & 3,705 & 96.5 & 12,832 & 99.6 & 6,491 & 95.9 & 2,038 & 58.2 & 2,552 & 29.6 & 1,459 & 6.9 \\
\hline 1991 & 29,612 & 52.3 & 3,655 & 95.0 & 13,033 & 99.8 & 6,584 & 96.4 & 1,976 & 59.8 & 2,710 & 31.0 & 1,653 & 7.9 \\
\hline 1992 & 29,802 & 52.7 & 3,721 & 95.7 & 13,197 & 99.5 & 6,770 & 97.3 & 2,018 & 61.6 & 2,666 & 30.7 & 1,431 & 7.0 \\
\hline 1993 & 30,236 & 53.4 & 3,750 & 95.5 & 13,359 & 99.6 & 6,890 & 97.1 & 2,049 & 61.6 & 2,727 & 31.8 & 1,461 & 7.2 \\
\hline 1994 & 31,586 & 54.2 & 3,965 & 97.0 & 13,701 & 99.3 & 7,358 & 96.6 & 2,104 & 60.4 & 2,831 & 31.2 & 1,628 & 8.0 \\
\hline 1995 & 31,865 & 54.6 & 4,041 & 95.3 & 13,800 & 99.0 & 7,554 & 96.7 & 2,150 & 59.5 & 2,711 & 31.0 & 1,608 & 8.0 \\
\hline
\end{tabular}


<CG.A.4> continued

\begin{tabular}{|c|c|c|c|c|c|c|c|c|c|c|c|c|c|c|}
\hline \multirow{3}{*}{ Year } & \multicolumn{14}{|c|}{ School enrollment and enrollment rates of females, by age } \\
\hline & \multicolumn{2}{|c|}{ Total, 5 to 34} & \multicolumn{2}{|c|}{5 and 6} & \multicolumn{2}{|c|}{7 to 13} & \multicolumn{2}{|c|}{14 to 17} & \multicolumn{2}{|c|}{18 and 19} & \multicolumn{2}{|c|}{20 to 24} & \multicolumn{2}{|c|}{25 to 34} \\
\hline & number & rate & number & rate & number & rate & number & rate & number & rate & number & rate & number & rate \\
\hline HS no. & H442 & H442 & H443 & H443 & H444 & H444 & H445 & $H 445$ & $H 446$ & $H 446$ & $H 447$ & $H 447$ & $H 448$ & $H 448$ \\
\hline Units & 000 & $\%$ & 000 & $\%$ & 000 & $\%$ & 000 & $\%$ & 000 & $\%$ & 000 & $\%$ & 000 & $\%$ \\
\hline col. no. & (1) & (2) & (3) & (4) & (5) & (6) & (7) & (8) & (9) & (10) & (11) & (12) & (13) & (14) \\
\hline $1940^{2}$ & $13,145^{3}$ & 56.9 & 904 & 43.7 & 7,428 & 95.2 & 3,840 & 79.7 & 680 & 26.9 & 294 & 5.0 & --- & --- \\
\hline 1945 & $12,855^{3}$ & 57.3 & 1,410 & 61.3 & 7,291 & 98.4 & 3,481 & 78.7 & 476 & 20.3 & 197 & 3.3 & --- & -- \\
\hline 1946 & $12,983^{3}$ & 57.5 & 1,516 & 63.3 & 7,381 & 98.5 & 3,465 & 80.1 & 415 & 18.0 & 206 & 3.4 & --- & -- \\
\hline 1947 & 13,111 & 38.0 & 1,520 & 58.7 & 7,521 & 98.5 & 3,373 & 79.8 & 420 & 18.5 & 236 & 3.9 & 41 & 0.3 \\
\hline 1948 & 13,399 & 38.4 & 1,608 & 56.8 & 7,698 & 98.0 & 3,388 & 81.7 & 452 & 20.3 & 206 & 3.4 & 48 & 0.4 \\
\hline 1949 & 13,794 & 39.2 & 1,679 & 58.4 & 8,045 & 98.7 & 3,331 & 80.7 & 435 & 19.9 & 215 & 3.7 & 89 & 0.7 \\
\hline 1950 & $14,337^{4}$ & 48.4 & 1,655 & 59.5 & 8,449 & 98.7 & 3,420 & 82.3 & 519 & 24.3 & 268 & 4.6 & $27^{5}$ & 0.4 \\
\hline 1951 & $14,692^{4}$ & 49.1 & 1,548 & 54.0 & 8,798 & 99.1 & 3,602 & 85.2 & 440 & 21.3 & 244 & 4.3 & $60^{5}$ & 1.0 \\
\hline 1952 & 15,336 & 41.9 & 1,820 & 54.6 & 9,032 & 98.9 & 3,682 & 85.0 & 450 & 22.1 & 274 & 4.9 & 78 & 0.6 \\
\hline 1953 & 15,822 & 43.0 & 2,003 & 56.6 & 9,120 & 99.6 & 3,695 & 85.0 & 538 & 25.9 & 346 & 6.4 & 120 & 0.9 \\
\hline 1954 & 17,324 & 46.3 & 2,697 & 78.3 & 9,813 & 99.6 & 3,782 & 85.4 & 538 & 25.4 & 322 & 6.0 & 171 & 1.4 \\
\hline 1955 & 17,853 & 47.0 & 2,700 & 78.1 & 10,304 & 99.1 & 3,873 & 85.2 & 480 & 22.5 & 324 & 6.1 & 173 & 1.4 \\
\hline 1956 & 18,801 & 48.7 & 2,758 & 78.2 & 10,767 & 99.4 & 4,138 & 87.3 & 598 & 27.4 & 362 & 6.8 & 178 & 1.5 \\
\hline 1957 & 19,657 & 50.0 & 2,866 & 79.0 & 11,121 & 99.5 & 4,421 & 87.8 & 629 & 28.1 & 439 & 8.2 & 181 & 1.5 \\
\hline 1958 & 20,404 & 51.0 & 2,978 & 80.2 & 11,564 & 99.4 & 4,591 & 87.6 & 667 & 29.4 & 393 & 7.3 & 211 & 1.8 \\
\hline 1959 & 21,178 & 52.0 & 3,064 & 80.5 & 12,070 & 99.6 & 4,798 & 89.0 & 683 & 29.2 & 391 & 7.1 & 172 & 1.5 \\
\hline 1960 & 22,025 & 52.8 & 3,146 & 80.6 & 12,547 & 99.6 & 4,993 & 89.2 & 754 & 30.0 & 414 & 7.4 & 171 & 1.7 \\
\hline 1961 & 22,764 & 53.4 & 3,236 & 81.4 & 12,634 & 99.3 & 5,458 & 90.5 & 782 & 28.6 & 479 & 8.3 & 175 & 1.5 \\
\hline 1962 & 23,252 & 54.0 & 3,252 & 81.7 & 12,631 & 99.4 & 5,708 & 90.3 & 932 & 33.7 & 548 & 9.1 & 181 & 1.6 \\
\hline 1963 & 24,113 & 54.9 & 3,328 & 82.6 & 12,923 & 99.6 & 6,115 & 91.6 & 881 & 32.3 & 649 & 10.3 & 217 & 1.9 \\
\hline 1964 & 24,809 & 55.3 & 3,364 & 83.2 & 13,177 & 99.2 & 6,356 & 91.8 & 958 & 33.7 & 716 & 10.9 & 238 & 2.1 \\
\hline 1965 & 25,710 & 56.0 & 3,440 & 84.4 & 13,518 & 99.4 & 6,420 & 92.8 & 1,241 & 37.7 & 801 & 11.8 & 290 & 2.6 \\
\hline 1966 & 26,337 & 56.1 & 3,537 & 85.7 & 13,756 & 99.5 & 6,523 & 92.9 & 1,335 & 37.7 & 880 & 12.4 & 306 & 2.7 \\
\hline 1967 & 27,144 & 56.5 & 3,632 & 88.2 & 13,944 & 99.4 & 6,662 & 92.6 & 1,390 & 40.3 & 1,139 & 15.1 & 375 & 3.2 \\
\hline 1968 & 27,513 & 56.1 & 3,558 & 88.0 & 14,106 & 99.3 & 6,919 & 93.4 & 1,425 & 41.3 & 1,121 & 14.3 & 383 & 3.2 \\
\hline 1969 & 28,135 & 56.3 & 3,532 & 89.1 & 14,223 & 99.5 & 7,078 & 93.1 & 1,465 & 41.8 & 1,310 & 16.0 & 526 & 4.2 \\
\hline
\end{tabular}


<CG.A.4> continued

\begin{tabular}{|c|c|c|c|c|c|c|c|c|c|c|c|c|c|c|}
\hline \multirow{3}{*}{ Year } & \multicolumn{14}{|c|}{ School enrollment and enrollment rates of females, by age (continued) } \\
\hline & \multicolumn{2}{|c|}{ Total, 5 to 34} & \multicolumn{2}{|c|}{5 and 6} & \multicolumn{2}{|c|}{7 to 13} & \multicolumn{2}{|c|}{14 to 17} & \multicolumn{2}{|c|}{18 and 19} & \multicolumn{2}{|c|}{20 to 24} & \multicolumn{2}{|c|}{25 to 34} \\
\hline & number & rate & number & rate & number & rate & number & rate & number & rate & number & rate & number & rate \\
\hline HS no. & H442 & H442 & H443 & H443 & H444 & H444 & H445 & H445 & $H 446$ & $H 446$ & $H 447$ & $H 447$ & $H 448$ & $H 448$ \\
\hline Units & 000 & $\%$ & 000 & $\%$ & 000 & $\%$ & 000 & $\%$ & 000 & $\%$ & 000 & $\%$ & 000 & $\%$ \\
\hline col. no. & (1) & (2) & (3) & (4) & (5) & (6) & (7) & (8) & (9) & (10) & (11) & (12) & (13) & (14) \\
\hline 1970 & 28,254 & 55.5 & 3,455 & 90.2 & 14,255 & 99.4 & 7,265 & 93.4 & 1,501 & 41.6 & 1,297 & 15.2 & 480 & 3.8 \\
\hline 1971 & 28,515 & 55.2 & 3,368 & 92.3 & 14,190 & 99.4 & 7,424 & 93.7 & 1,617 & 43.4 & 1,389 & 15.7 & 527 & 4.0 \\
\hline 1972 & 27,980 & 53.8 & 3,120 & 92.2 & 13,712 & 99.3 & 7,471 & 92.6 & 1,601 & 41.8 & 1,449 & 16.0 & 627 & 4.5 \\
\hline 1973 & 27,689 & 52.6 & 3,066 & 92.9 & 13,405 & 99.3 & 7,509 & 92.1 & 1,500 & 38.2 & 1,540 & 16.7 & 669 & 4.6 \\
\hline 1974 & 28,075 & 52.7 & 3,140 & 93.9 & 13,183 & 99.5 & 7,624 & 92.5 & 1,644 & 40.7 & 1,615 & 17.3 & 869 & 5.8 \\
\hline 1975 & 28,365 & 52.6 & 3,244 & 95.1 & 12,837 & 99.6 & 7,657 & 92.6 & 1,825 & 44.2 & 1,786 & 18.7 & 1,016 & 6.5 \\
\hline 1976 & 28,323 & 52.1 & 3,279 & 95.5 & 12,503 & 99.3 & 7,634 & 92.8 & 1,861 & 44.4 & 2,021 & 20.8 & 1,025 & 6.3 \\
\hline 1977 & 28,246 & 51.7 & 3,187 & 96.9 & 12,301 & 99.5 & 7,594 & 93.0 & 1,844 & 44.0 & 1,988 & 20.0 & 1,332 & 8.0 \\
\hline 1978 & 27,544 & 50.4 & 2,944 & 95.5 & 12,083 & 99.3 & 7,542 & 93.5 & 1,798 & 43.0 & 1,955 & 19.4 & 1,222 & 7.1 \\
\hline 1979 & 27,258 & 49.7 & 2,843 & 95.2 & 11,860 & 99.4 & 7,290 & 92.6 & 1,819 & 43.4 & 2,061 & 20.2 & 1,385 & 7.8 \\
\hline 1980 & 27,115 & 49.2 & 2,882 & 96.4 & 11,641 & 99.3 & 7,089 & 93.1 & 1,910 & 45.8 & 2,147 & 20.8 & 1,446 & 7.9 \\
\hline 1981 & 27,482 & 48.4 & 2,904 & 93.8 & 11,771 & 99.4 & 7,065 & 93.9 & 1,958 & 47.5 & 2,234 & 20.8 & 1,550 & 8.0 \\
\hline 1982 & 27,227 & 48.1 & 2,977 & 95.3 & 11,579 & 99.3 & 6,820 & 94.0 & 1,899 & 46.8 & 2,363 & 22.1 & 1,589 & 8.0 \\
\hline 1983 & 26,891 & 47.6 & 3,048 & 95.8 & 11,391 & 99.3 & 6,770 & 94.9 & 1,983 & 50.3 & 2,138 & 20.1 & 1,561 & 7.8 \\
\hline 1984 & 26,690 & 47.3 & 3,112 & 95.1 & 11,190 & 99.4 & 6,774 & 94.7 & 1,800 & 47.9 & 2,235 & 21.2 & 1,579 & 7.7 \\
\hline 1985 & 27,125 & 47.8 & 3,274 & 97.0 & 11,182 & 99.3 & 6,830 & 94.5 & 1,864 & 51.0 & 2,309 & 22.5 & 1,666 & 8.0 \\
\hline 1986 & 27,079 & 47.6 & 3,373 & 94.6 & 11,221 & 94.5 & 6,772 & 90.6 & 1,874 & 53.5 & 2,279 & 24.2 & 1,560 & 7.6 \\
\hline 1987 & 27,396 & 48.1 & 3,376 & 94.6 & 11,463 & 99.4 & 6,603 & 94.5 & 1,936 & 53.4 & 2,324 & 24.0 & 1,694 & 7.9 \\
\hline 1988 & 27,565 & 48.3 & 3,471 & 96.0 & 11,714 & 99.7 & 6,363 & 94.8 & 2,028 & 55.2 & 2,367 & 24.7 & 1,622 & 7.5 \\
\hline 1989 & 27,798 & 48.9 & 3,439 & 95.2 & 11,922 & 99.4 & 6,164 & 95.3 & 2,063 & 55.4 & 2,498 & 27.1 & 1,712 & 7.9 \\
\hline 1990 & 28,222 & 49.8 & 3,502 & 96.4 & 12,184 & 99.7 & 6,163 & 95.7 & 2,006 & 56.3 & 2,532 & 27.7 & 1,835 & 8.5 \\
\hline 1991 & 28,596 & 50.5 & 3,522 & 95.8 & 12,412 & 99.5 & 6,205 & 95.6 & 1,993 & 59.4 & 2,695 & 29.4 & 1,769 & 8.3 \\
\hline 1992 & 29,218 & 51.7 & 3,531 & 95.2 & 12,571 & 99.2 & 6,363 & 96.0 & 1,994 & 61.2 & 2,938 & 32.5 & 1,820 & 8.6 \\
\hline 1993 & 29,219 & 51.8 & 3,547 & 95.2 & 12,752 & 99.4 & 6,461 & 95.9 & 2,014 & 61.7 & 2,662 & 29.8 & 1,784 & 8.6 \\
\hline 1994 & 30,924 & 53.3 & 3,787 & 96.4 & 13,068 & 99.4 & 7,056 & 96.6 & 2,076 & 60.0 & 3,025 & 32.8 & 1,911 & 9.1 \\
\hline 1995 & 31,031 & 53.5 & 3,860 & 96.8 & 13,203 & 98.8 & 7,093 & 95.7 & 2,124 & 59.2 & 2,859 & 31.9 & 1,892 & 9.2 \\
\hline
\end{tabular}


Sources: <CG.A.4.1> to <CG.A.4.42>, 1940 to 1991, U.S. Department of Education, 120 Years of American Education: A Statistical Portrait (Washington, D.C.: U.S. G.P.O., 1993), table 3. The underlying sources are: 1940, U.S. Bureau of the Census, U.S. Census of Population: 1950, vol. II, part 1; 1945 to 1969, Current Population Reports, series P-20, nos. 10, 24, 30, 34, 45, 52, 54, 66, 74, 80, 93, 101, 110, 117, 126, 129, 148, 162, 167, 190, 206, and 222; 1970 to 1991, Current Population Survey, survey data files. 1992 to 1995, Current Population Reports, series P-20, nos. 474, 479, 487, and 495.

The estimates are based on data obtained in October in the Current Population Survey of the Bureau of the Census, except that data shown for 1940 are based on complete enumeration of the population and were published in volume II of the 1950 census reports on population. Except for 1940, data are for the civilian population excluding the relatively small number in institutions. Data shown for 1940 relate to the total population, including those in institutions and all members of the Armed Forces (about 267,000) enumerated on April 1.

The school enrollment statistics from the Current Population Survey (CPS) are based on replies to the enumerator's inquiry as to whether the person was enrolled in school. In the Census of Population for 1940 and 1950, and in the CPS, 1954 to 1991, enrollment was defined as enrollment in "regular" schools only - that is, schools where enrollment may lead toward an elementary or high school diploma, or to a college, university, or professional degree. Such schools included public and private nursery schools, kindergartens, elementary and secondary schools, colleges, universities, and professional schools. Enrollment could be either full-time or part-time, day or night.

If a person was receiving regular instruction at home from a tutor and if the instruction was considered comparable to that of a regular school or college, the person was counted as enrolled. Enrollment in a correspondence course was counted only if the person received credit in the regular school system. Enrollments in business and trade schools at the postsecondary level were excluded if the coursework did not lead to a degree.

Children in kindergarten were included in the "regular" school enrollment figures in the Current Population Survey beginning in 1950; children enrolled in nursery school were included in 1967. Children enrolled in kindergarten were not included in the "regular" school enrollment figures in the 1950 Census of Population; however, they have been included here to make the data comparable with earlier years and with current practice. In censuses prior to 1950, no attempt was made to exclude children in kindergarten so that the statistics for those years include varying proportions attending kindergarten.

Information on school enrollment is also collected and published by the Department of Education. These data are obtained from reports of school surveys and censuses. They are, however, only roughly comparable with data collected by the Bureau of the Census from households, because of differences in definitions, time references, population coverage, and enumeration methods.

Footnotes:

11: Unless otherwise noted, enrollment data are for October.

12: As of April 1.

13: Data for 1940 through 1946 are for ages 5 to 24.

14: Data for 1950 and 1951 are for ages 5 to 29.

15: 25 to 29 years old. 
<CG.A.6> Average daily attendance in, and the average school term of, public elementary and secondary schools: $1869-70$ to $1994-95$

\begin{tabular}{|c|c|c|c|}
\hline \multirow[b]{2}{*}{ School year } & \multicolumn{3}{|c|}{ School attendance } \\
\hline & $\begin{array}{l}\text { Average daily } \\
\text { attendance }\end{array}$ & $\begin{array}{c}\text { Average length of school } \\
\text { term }\end{array}$ & $\begin{array}{l}\text { Average number of days } \\
\text { attended per pupil enrolled }\end{array}$ \\
\hline Units & thousands & days & days \\
\hline HS no. & H52O & $H 521$ & H522 \\
\hline col. no. & (1) & (2) & (3) \\
\hline 1869-70 & $4,077,000$ & 132.2 & 78.4 \\
\hline $1870-71$ & $4,545,000$ & 132.1 & 79.4 \\
\hline $1871-72$ & $4,659,000$ & 133.4 & 79.5 \\
\hline $1872-73$ & $4,745,000$ & 129.1 & 76.5 \\
\hline $1873-74$ & $5,051,000$ & 128.8 & 77.0 \\
\hline 1874-75 & $5,248,000$ & 134.4 & 77.9 \\
\hline $1875-76$ & $5,291,000$ & 133.1 & 79.4 \\
\hline $1876-77$ & $5,427,000$ & 132.1 & 80.0 \\
\hline $1877-78$ & $5,783,000$ & 132.0 & 80.9 \\
\hline 1878-79 & $5,876,000$ & 130.2 & 80.5 \\
\hline $1879-80$ & $6,144,000$ & 130.3 & 81.1 \\
\hline $1880-81$ & $6,146,000$ & 130.0 & 80.0 \\
\hline 1881-82 & $6,331,000$ & 131.2 & 81.3 \\
\hline $1882-83$ & $6,652,000$ & 129.8 & 81.1 \\
\hline $1883-84$ & $7,056,000$ & 129.1 & 82.9 \\
\hline 1884-85 & $7,298,000$ & 130.7 & 83.6 \\
\hline $1885-86$ & $7,526,000$ & 130.4 & 84.1 \\
\hline $1886-87$ & $7,682,000$ & 131.3 & 84.9 \\
\hline 1887-88 & $7,907,000$ & 132.3 & 85.9 \\
\hline $1888-89$ & $8,006,000$ & 133.7 & 86.4 \\
\hline $1889-90$ & $8,154,000$ & 134.7 & 86.3 \\
\hline $1890-91$ & $8,329,000$ & 135.7 & 86.6 \\
\hline 1891-92 & $8,561,000$ & 136.9 & 88.4 \\
\hline 1892-93 & $8,856,000$ & 136.3 & 89.6 \\
\hline 1893-94 & $9,188,000$ & 139.5 & 91.6 \\
\hline 1894-95 & $9,549,000$ & 139.5 & 93.5 \\
\hline 1895-96 & $9,781,000$ & 140.5 & 94.8 \\
\hline 1896-97 & $10,053,000$ & 142.0 & 96.3 \\
\hline 1897-98 & $10,356,000$ & 143.0 & 98.0 \\
\hline 1898-99 & $10,389,000$ & 143.0 & 97.9 \\
\hline 1899-1900 & $10,633,000$ & 144.3 & 99.0 \\
\hline $1900-01$ & $10,716,000$ & 143.7 & 98.0 \\
\hline 1901-02 & $11,064,000$ & 144.7 & 100.6 \\
\hline 1903-03 & $11,055,000$ & 147.2 & 101.7 \\
\hline 1903-04 & $11,318,000$ & 146.7 & 102.1 \\
\hline 1904-05 & $11,482,000$ & 150.9 & 105.2 \\
\hline 1905-06 & $11,712,000$ & 150.6 & 106.0 \\
\hline 1906-07 & $11,926,000$ & 151.8 & 107.3 \\
\hline 1907-08 & $12,154,000$ & 154.1 & 109.8 \\
\hline
\end{tabular}


<CG.A.6> continued

\begin{tabular}{|c|c|c|c|}
\hline \multirow[b]{2}{*}{ School year } & \multicolumn{3}{|c|}{ School attendance (continued) } \\
\hline & $\begin{array}{l}\text { Average daily } \\
\text { attendance }\end{array}$ & $\begin{array}{c}\text { Average length of school } \\
\text { term }\end{array}$ & $\begin{array}{l}\text { Average number of days } \\
\text { attended per pupil enrolled }\end{array}$ \\
\hline Units & thousands & days & days \\
\hline col. no. & (1) & (2) & (3) \\
\hline 1908-09 & $12,685,000$ & 155.3 & 112.6 \\
\hline $1909-10$ & $12,827,000$ & 157.5 & 113.0 \\
\hline $1910-11$ & $12,872,000$ & 156.8 & 111.8 \\
\hline 1911-12 & $13,302,000$ & 158.8 & 115.6 \\
\hline $1912-13$ & $13,614,000$ & 158.1 & 115.6 \\
\hline 1913-14 & $14,216,000$ & 158.7 & 117.8 \\
\hline 1914-15 & $14,986,000$ & 159.4 & 121.2 \\
\hline $1915-16$ & $15,359,000$ & 160.3 & 120.9 \\
\hline $1917-18$ & $15,549,000$ & 160.7 & 119.8 \\
\hline $1919-20$ & $16,150,000$ & 161.9 & 121.2 \\
\hline $1921-22$ & $18,432,000$ & 164.0 & 130.6 \\
\hline $1923-24$ & $19,132,000$ & 168.3 & 132.5 \\
\hline $1925-26$ & $19,856,000$ & 169.3 & 135.9 \\
\hline $1927-28$ & $20,608,000$ & 171.5 & 140.4 \\
\hline 1929-30 & $21,265,000$ & 172.7 & 143.0 \\
\hline 1931-32 & $22,245,000$ & 171.2 & 144.9 \\
\hline 1933-34 & $22,458,000$ & 171.6 & 145.8 \\
\hline 1935-36 & $22,299,000$ & 173.0 & 146.3 \\
\hline $1937-38$ & $22,298,000$ & 173.9 & 149.3 \\
\hline $1939-40$ & $22,042,000$ & 175.0 & 151.7 \\
\hline 1941-42 & $21,031,000$ & 174.7 & 149.6 \\
\hline 1943-44 & $19,603,000$ & 175.5 & 147.9 \\
\hline $1945-46$ & $19,849,000$ & 176.8 & 150.6 \\
\hline $1947-48$ & $20,910,000$ & 177.6 & 155.1 \\
\hline $1949-50$ & $22,284,000$ & 177.9 & 157.9 \\
\hline 1951-52 & $23,257,000$ & 178.2 & 156.0 \\
\hline 1953-54 & $25,643,871$ & 178.6 & 158.9 \\
\hline 1955-56 & $27,740,149$ & 178.0 & 158.5 \\
\hline $1957-58$ & $29,722,275$ & 177.6 & 157.4 \\
\hline 1959-60* & $32,477,440$ & 178.0 & 160.2 \\
\hline 1961-62 & $34,682,340$ & 179.1 & 162.3 \\
\hline 1963-64 & $37,405,058$ & 179.0 & 163.2 \\
\hline 1965-66 & $39,154,497$ & 178.9 & 163.5 \\
\hline \begin{tabular}{|l|}
$1967-68$ \\
\end{tabular} & $40,827,965$ & 178.8 & 163.2 \\
\hline 1969-70 & $41,934,376$ & 178.9 & 161.7 \\
\hline 1970-71 & $42,428,000$ & (NA) & (NA) \\
\hline 1971-72 & $42,254,272$ & 179.3 & 161.7 \\
\hline 1972-73 & $42,179,000$ & (NA) & (NA) \\
\hline 1973-74 & $41,438,054$ & 178.7 & 159.5 \\
\hline 1974-75 & $41,524,000$ & (NA) & (NA) \\
\hline $1975-76$ & $41,269,720$ & 178.3 & 161.1 \\
\hline
\end{tabular}

$-50-$ 
$<$ CG.A.6> continued

\begin{tabular}{|c|c|c|c|}
\hline \multirow[b]{2}{*}{ School year } & \multicolumn{3}{|c|}{ School attendance (continued) } \\
\hline & $\begin{array}{l}\text { Average daily } \\
\text { attendance }\end{array}$ & $\begin{array}{c}\text { Average length of school } \\
\text { term }\end{array}$ & $\begin{array}{l}\text { Average number of days } \\
\text { attended per pupil enrolled }\end{array}$ \\
\hline Units & thousands & days & days \\
\hline col. no. & (1) & (2) & (3) \\
\hline 1976-77 & $40,832,000$ & (NA) & $(\mathrm{NA})$ \\
\hline $1977-78$ & $40,079,590$ & (NA) & (NA) \\
\hline 1978-79 & $39,075,000$ & (NA) & (NA) \\
\hline $1979-80$ & $38,288,911$ & $178.5^{1}$ & $160.8^{1}$ \\
\hline $1980-81$ & $37,703,744$ & 178.2 & 160.7 \\
\hline $1981-82$ & $37,094,652$ & $(\mathrm{NA})$ & $(\mathrm{NA})$ \\
\hline $1982-83$ & $36,635,868$ & $(\mathrm{NA})$ & $(\mathrm{NA})$ \\
\hline $1983-84$ & $36,362,978$ & (NA) & (NA) \\
\hline $1984-85$ & $36,404,261$ & (NA) & (NA) \\
\hline $1985-86$ & $36,523,103$ & (NA) & (NA) \\
\hline $1986-87$ & $36,863,867$ & (NA) & (NA) \\
\hline $1987-88$ & $37,050,707$ & (NA) & (NA) \\
\hline $1988-89$ & $37,268,072$ & (NA) & $(\mathrm{NA})$ \\
\hline $1989-90$ & $37,799,296$ & (NA) & (NA) \\
\hline $1990-91$ & $38,426,543$ & 179.8 & (NA) \\
\hline $1991-92$ & $38,960,783$ & (NA) & (NA) \\
\hline $1992-93$ & $39,570,462$ & (NA) & (NA) \\
\hline $1993-94$ & $40,146,393$ & (NA) & (NA) \\
\hline 1994-95 & $40,720,763$ & (NA) & (NA) \\
\hline
\end{tabular}

Sources: <CG.A.6.1> to <CG.A.6.3>, 1869-70 to 1989-90, U.S. Department of Education, 120 Years of American Education: A Statistical Portrait (Washington, D.C.: U.S. G.P.O., 1993), table 14, although see below for additional source for <CG.A.6.1>. The underlying sources are: U.S. Office of Education, Annual Report of the United States Commissioner of Education; U.S. Office of Education, Biennial Survey of Education in the United States, and U.S. Department of Education, Digest of Education Statistics, annual issues (Washington, D.C.: U.S. G.P.O.). <CG.A.6.1>, even years 1953-54 to 1977-78, and all years 1979-80 to 1994-95, Digest 1997, table 51. <CG.A.6.2>, 1990-91, Digest of Education Statistics 1997, table 39

Figures for average daily attendance in public schools were computed by dividing the total number of days attended by all pupils enrolled by the number of days school was actually in session. Only days when the pupils were under the guidance and direction of teachers are considered as days in session.

Footnotes:

11: Estimated by the National Center for Education Statistics. 
<CG.A.7> Public elementary and secondary day school teachers and instructional staff, counts and average annual salaries: 1869-70 to 1994-95

\begin{tabular}{|c|c|c|c|c|c|c|c|c|c|c|}
\hline \multirow[t]{2}{*}{$\begin{array}{l}\text { School } \\
\text { year }\end{array}$} & \multicolumn{2}{|c|}{$\begin{array}{l}\text { Elementary and } \\
\text { secondary schools }\end{array}$} & \multirow{2}{*}{$\begin{array}{c}\text { Elementary } \\
\text { school } \\
\text { classroom } \\
\text { teachers }^{2}\end{array}$} & \multirow{2}{*}{$\begin{array}{l}\text { Secondary } \\
\text { school } \\
\text { classroom } \\
\text { teachers }\end{array}$} & \multicolumn{2}{|c|}{$\begin{array}{c}\text { Elementary and } \\
\text { secondary school } \\
\text { classroom teachers }\end{array}$} & \multicolumn{4}{|c|}{ Average annual salary (current dollars) } \\
\hline & $\begin{array}{c}\text { Instructional } \\
\text { staff }\end{array}$ & \begin{tabular}{|l|} 
Classroom \\
teachers $^{1,2}$
\end{tabular} & & & Males & Females & \begin{tabular}{|c|} 
All \\
Instructional $_{\text {staff }^{3}}$
\end{tabular} & \begin{tabular}{|c} 
All \\
classroom \\
teachers
\end{tabular} & $\begin{array}{c}\text { Elementary } \\
\text { school } \\
\text { classroom } \\
\text { teachers }\end{array}$ & $\begin{array}{c}\text { Secondary } \\
\text { school } \\
\text { classroom } \\
\text { teachers }\end{array}$ \\
\hline Units & thousands & thousands & thousands & thousands & thousands & thousands & $\begin{array}{l}\text { current } \\
\text { dollars }\end{array}$ & $\begin{array}{l}\text { current } \\
\text { dollars }\end{array}$ & $\begin{array}{l}\text { current } \\
\text { dollars }\end{array}$ & $\begin{array}{l}\text { current } \\
\text { dollars }\end{array}$ \\
\hline HS no. & H523 & $H 526^{2}$ & new & New & $H 527^{2}$ & $H 528^{2}$ & $H 524^{3}$ & new & new & new \\
\hline col. no. & (1) & (2) & (3) & (4) & (5) & (6) & (7) & (8) & (9) & (10) \\
\hline $1869-70$ & ---- & 201 & ---- & ---- & 78 & 123 & 189 & ---- & ---- & ---- \\
\hline $1870-71$ & ---- & 220 & ---- & ---- & 90 & 130 & (NA) & ---- & ---- & ---- \\
\hline 1871-72 & ---- & 230 & ---- & ---- & 95 & 135 & $(\mathrm{NA})$ & ---- & ---- & ---- \\
\hline $1872-73$ & ---- & 238 & ---- & ---- & 98 & 140 & (NA) & ---- & ---- & ---- \\
\hline $1873-74$ & ---- & 248 & ---- & ---- & 103 & 145 & (NA) & ---- & ---- & ---- \\
\hline 1874-75 & ---- & 258 & --- & --- & 109 & 149 & (NA) & ---- & ---- & --- \\
\hline $1875-76$ & ---- & 260 & ---- & --- & 110 & 150 & (NA) & ---- & ---- & --- \\
\hline 1876-77 & ---- & 267 & ---- & ---- & 114 & 153 & (NA) & ---- & ---- & ---- \\
\hline 1877-78 & ---- & 277 & ---- & ---- & 119 & 158 & $(\mathrm{NA})$ & ---- & ---- & ---- \\
\hline $1878-79$ & ---- & 280 & --- & ---- & 121 & 159 & $(\mathrm{NA})$ & --- & --- & ---- \\
\hline $1879-80$ & ---- & 287 & ---- & ---- & 123 & 164 & 195 & ---- & ---- & ---- \\
\hline $1880-81$ & ---- & 294 & ---- & ---- & 123 & 171 & (NA) & ---- & ---- & ---- \\
\hline $1881-82$ & ---- & 299 & ---- & ---- & 119 & 180 & (NA) & ---- & ---- & ---- \\
\hline 1882-83 & ---- & 304 & ---- & ---- & 116 & 188 & (NA) & ---- & ---- & ---- \\
\hline 1883-84 & ---- & 314 & ---- & ---- & 119 & 195 & (NA) & ---- & ---- & ---- \\
\hline 1884-85 & ---- & 326 & ---- & ---- & 122 & 204 & 224 & ---- & ---- & ---- \\
\hline $1885-86$ & ---- & 331 & ---- & ---- & 124 & 208 & (NA) & ---- & ---- & ---- \\
\hline $1886-87$ & ---- & 339 & ---- & ---- & 127 & 212 & (NA) & ---- & ---- & ---- \\
\hline $1887-88$ & ---- & 347 & ---- & ---- & 126 & 221 & (NA) & ---- & ---- & ---- \\
\hline 1888-89 & ---- & 357 & ---- & ---- & 124 & 232 & (NA) & ---- & ---- & ---- \\
\hline $1889-90$ & ---- & 364 & 355 & 9 & 126 & 238 & 252 & ---- & ---- & --- \\
\hline $1890-91$ & ---- & 368 & (NA) & (NA) & 123 & 245 & (NA) & ---- & ---- & ---- \\
\hline 1891-92 & --- & 374 & (NA) & (NA) & 122 & 253 & (NA) & --- & ---- & --- \\
\hline
\end{tabular}


<CG.A.7> continued

\begin{tabular}{|c|c|c|c|c|c|c|c|c|c|c|}
\hline \multirow[t]{2}{*}{$\begin{array}{l}\text { School } \\
\text { year }\end{array}$} & \multicolumn{2}{|c|}{$\begin{array}{c}\text { Elementary and } \\
\text { secondary schools }\end{array}$} & \multirow{2}{*}{$\begin{array}{l}\text { Elementary } \\
\text { school } \\
\text { classroom } \\
\text { teachers }^{2}\end{array}$} & \multirow{2}{*}{$\begin{array}{c}\text { Secondary } \\
\text { school } \\
\text { classroom } \\
\text { teachers }^{2}\end{array}$} & \multicolumn{2}{|c|}{$\begin{array}{c}\text { Elementary and } \\
\text { secondary school } \\
\text { classroom teachers }^{1,2}\end{array}$} & \multicolumn{4}{|c|}{ Average annual salary (current dollars) } \\
\hline & $\begin{array}{c}\text { Instructional } \\
\text { staff }\end{array}$ & $\begin{array}{l}\text { Classroom } \\
\text { teachers }^{1,2}\end{array}$ & & & Males & Females & \begin{tabular}{|c|} 
All \\
Instructional \\
staff $^{3}$
\end{tabular} & $\begin{array}{c}\text { All } \\
\text { classroom } \\
\text { teachers }^{4}\end{array}$ & \begin{tabular}{|} 
Elementary \\
school \\
classroom \\
teachers
\end{tabular} & $\begin{array}{l}\text { Secondary } \\
\text { school } \\
\text { classroom } \\
\text { teachers } \\
\end{array}$ \\
\hline Units & thousands & thousands & thousands & thousands & thousands & thousands & $\begin{array}{l}\text { current } \\
\text { dollars }\end{array}$ & $\begin{array}{l}\text { current } \\
\text { dollars }\end{array}$ & $\begin{array}{l}\text { current } \\
\text { dollars }\end{array}$ & $\begin{array}{l}\text { current } \\
\text { dollars }\end{array}$ \\
\hline col. no. & (1) & (2) & (3) & (4) & (5) & (6) & (7) & $(8)$ & (9) & (10) \\
\hline $1892-93$ & ---- & 383 & (NA) & (NA) & 122 & 261 & (NA) & ---- & ---- & $\begin{array}{c}--- \\
\end{array}$ \\
\hline $1893-94$ & ---- & 389 & (NA) & (NA) & 125 & 264 & (NA) & ---- & ---- & ---- \\
\hline $1894-95$ & ---- & 398 & (NA) & (NA) & 130 & 268 & 286 & ---- & ---- & ---- \\
\hline $1895-96$ & ---- & 400 & (NA) & (NA) & 130 & 270 & (NA) & ---- & ---- & ---- \\
\hline $1896-97$ & $\begin{array}{ll}--- \\
\end{array}$ & 405 & (NA) & (NA) & 131 & 274 & (NA) & $\begin{array}{ll}--- \\
\end{array}$ & ---- & $\begin{array}{ll}--- \\
\end{array}$ \\
\hline $1897-98$ & $\begin{array}{ll}--- \\
\end{array}$ & 411 & (NA) & (NA) & 132 & 279 & (NA) & $\begin{array}{ll}--- \\
\end{array}$ & $\begin{array}{ll}--- \\
\end{array}$ & $\begin{array}{ll}--- \\
\end{array}$ \\
\hline 1898-99 & ---- & 414 & (NA) & (NA) & 131 & 283 & (NA) & ---- & $\begin{array}{ll}--- \\
\end{array}$ & $\begin{array}{ll}--- \\
\end{array}$ \\
\hline $1899-1900$ & ---- & 423 & 403 & 20 & 127 & 296 & 325 & ---- & ---- & ---- \\
\hline $1900-01$ & ---- & 432 & (NA) & (NA) & 126 & 306 & (NA) & ---- & ---- & ---- \\
\hline 1901-02 & ---- & 442 & (NA) & (NA) & 121 & 321 & (NA) & ---- & ---- & ---- \\
\hline 1902-03 & ---- & 449 & (NA) & (NA) & 117 & 332 & (NA) & ---- & ---- & --- \\
\hline 1903-04 & ---- & 455 & (NA) & (NA) & 114 & 341 & (NA) & ---- & ---- & ---- \\
\hline 1904-05 & ---- & 460 & (NA) & (NA) & 111 & 350 & 386 & ---- & ---- & ---- \\
\hline 1905-06 & ---- & 466 & (NA) & (NA) & 109 & 357 & (NA) & ---- & ---- & ---- \\
\hline 1906-07 & ---- & 481 & (NA) & (NA) & 104 & 377 & (NA) & ---- & ---- & ---- \\
\hline 1907-08 & ---- & 495 & (NA) & (NA) & 104 & 391 & (NA) & ---- & ---- & ---- \\
\hline 1908-09 & ---- & 506 & (NA) & (NA) & 108 & 398 & (NA) & ---- & ---- & ---- \\
\hline $1909-10$ & ---- & 523 & 482 & 42 & 110 & 413 & 485 & ---- & ---- & ---- \\
\hline $1910-11$ & ---- & 534 & (NA) & (NA) & 110 & 423 & 466 & ---- & ---- & ---- \\
\hline $1911-12$ & ---- & 547 & (NA) & (NA) & 115 & 433 & 492 & ---- & ---- & ---- \\
\hline $1912-13$ & ---- & 565 & (NA) & (NA) & 113 & 452 & 512 & $\begin{array}{l}--- \\
\end{array}$ & ---- & ---- \\
\hline 1913-14 & ---- & 580 & (NA) & (NA) & 115 & 465 & 525 & ---- & ---- & ---- \\
\hline 1914-15 & ---- & 604 & (NA) & (NA) & 118 & 486 & 543 & ---- & ---- & ---- \\
\hline 1915-16 & ---- & 622 & (NA) & (NA) & 123 & 499 & 563 & ---- & ---- & ---- \\
\hline
\end{tabular}

-53- 
$<$ CG.A.7> continued

\begin{tabular}{|c|c|c|c|c|c|c|c|c|c|c|}
\hline \multirow[t]{2}{*}{$\begin{array}{l}\text { School } \\
\text { year }\end{array}$} & \multicolumn{2}{|c|}{$\begin{array}{l}\text { Elementary and } \\
\text { secondary schools }\end{array}$} & \multirow{2}{*}{$\begin{array}{l}\text { Elementary } \\
\text { school } \\
\text { classroom } \\
\text { teachers }^{2}\end{array}$} & \multirow{2}{*}{$\begin{array}{c}\text { Secondary } \\
\text { school } \\
\text { classroom }^{2} \\
\text { teachers }\end{array}$} & \multicolumn{2}{|c|}{$\begin{array}{c}\text { Elementary and } \\
\text { secondary school } \\
\text { classroom teachers }\end{array}$} & \multicolumn{4}{|c|}{ Average annual salary (current dollars) } \\
\hline & $\begin{array}{c}\text { Instructional } \\
\text { staff }\end{array}$ & $\begin{array}{l}\text { Classroom } \\
\text { teachers }\end{array}$ & & & Males & Females & $\begin{array}{c}\text { All } \\
\begin{array}{c}\text { Instructional } \\
\text { staff }^{3}\end{array}\end{array}$ & \begin{tabular}{|c|} 
All \\
classroom \\
teachers
\end{tabular} & \begin{tabular}{|c|} 
Elementary \\
school \\
classroom \\
teachers \\
\end{tabular} & \begin{tabular}{|c|} 
Secondary \\
school \\
classroom \\
teachers
\end{tabular} \\
\hline Units & thousands & thousands & thousands & thousands & Thousands & thousands & $\begin{array}{l}\text { current } \\
\text { dollars }\end{array}$ & $\begin{array}{l}\text { Current } \\
\text { dollars }\end{array}$ & $\begin{array}{l}\text { current } \\
\text { dollars }\end{array}$ & $\begin{array}{l}\text { current } \\
\text { dollars }\end{array}$ \\
\hline HS no. & H523 & $H 526^{2}$ & new & New & $H 527^{2}$ & $H 528^{2}$ & $H 524^{3}$ & New & new & new \\
\hline col. no. & (1) & (2) & (3) & (4) & (5) & (6) & (7) & (8) & (9) & (10) \\
\hline 1917-18 & ---- & 651 & 562 & 84 & 105 & 546 & 635 & ---- & ---- & --- \\
\hline $1919-20$ & 700 & 680 & 576 & 102 & 96 & 584 & 871 & ---- & ---- & ---- \\
\hline $1921-22$ & 756 & 723 & 593 & 130 & 118 & 605 & 1,166 & ---- & --- & ---- \\
\hline 1923-24 & 787 & 761 & 617 & 144 & 129 & 633 & 1,227 & ---- & ---- & ---- \\
\hline $1925-26$ & 850 & 814 & 645 & 170 & 139 & 675 & 1,277 & ---- & ---- & ---- \\
\hline $1927-28$ & 868 & 832 & 643 & $189^{5}$ & 138 & 694 & 1,364 & --- & ---- & ---- \\
\hline $1929-30$ & 892 & 854 & 641 & $213^{5}$ & 142 & 712 & 1,420 & ---- & $\begin{array}{ll}--- \\
\end{array}$ & ----- \\
\hline 1931-32 & 901 & 872 & 640 & 231 & 154 & 718 & 1,417 & ---- & ---- & ---- \\
\hline 1933-34 & 880 & 847 & 619 & 228 & 162 & 685 & 1,227 & ---- & ---- & ---- \\
\hline $1935-36$ & 906 & 871 & 603 & 268 & 179 & 692 & 1,283 & ---- & ---- & ---- \\
\hline 1937-38 & 919 & 877 & 595 & $282^{5}$ & 185 & 692 & 1,374 & ---- & ---- & ---- \\
\hline $1939-40$ & 912 & 875 & 575 & $300^{5}$ & 195 & 681 & 1,441 & $\begin{array}{ll}--- \\
\end{array}$ & $\begin{array}{c}--- \\
\end{array}$ & ---- \\
\hline $1941-42$ & 898 & 859 & 559 & $300^{5}$ & 183 & 676 & 1,507 & $\begin{array}{c}--- \\
\end{array}$ & $\begin{array}{c}--- \\
\end{array}$ & ---- \\
\hline $1943-44$ & 865 & 828 & 539 & 289 & 127 & 701 & 1,728 & ---- & ---- & ---- \\
\hline $1945-46$ & 867 & 831 & 542 & 289 & 138 & 693 & 1,995 & --- & ---- & ---- \\
\hline 1947-48 & 907 & 861 & 555 & 306 & 162 & 699 & 2,639 & ---- & ---- & ---- \\
\hline $1949-50$ & 962 & 914 & 590 & 324 & 195 & 719 & 3,010 & ---- & ---- & ---- \\
\hline $1951-52$ & 1,012 & 963 & 620 & 343 & 235 & 728 & 3,450 & ---- & ---- & ---- \\
\hline 1953-54 & 1,098 & 1,032 & 658 & 375 & 254 & 779 & 3,825 & ---- & ---- & ---- \\
\hline $1955-56$ & 1,213 & 1,141 & 733 & 408 & 299 & 850 & 4,156 & ---- & ---- & ---- \\
\hline $1956-57$ & (NA) & (NA) & (NA) & (NA) & (NA) & (NA) & (NA) & ---- & ---- & ---- \\
\hline $1957-58$ & 1,333 & 1,238 & (NA) & (NA) & 332 & 906 & 4,702 & --- & --- & ---- \\
\hline 1958-59 & (NA) & (NA) & (NA) & (NA) & (NA) & (NA) & (NA) & --- & ---- & ---- \\
\hline
\end{tabular}


<CG.A.7> continued

\begin{tabular}{|c|c|c|c|c|c|c|c|c|c|c|}
\hline \multirow[t]{2}{*}{$\begin{array}{c}\text { School } \\
\text { year }\end{array}$} & \multicolumn{2}{|c|}{$\begin{array}{c}\text { Elementary and } \\
\text { secondary schools }\end{array}$} & \multirow{2}{*}{\begin{tabular}{|} 
Elementary \\
school \\
classroom \\
teachers $^{2}$
\end{tabular}} & \multirow{2}{*}{$\begin{array}{l}\text { Secondary } \\
\text { school } \\
\text { classroom }^{\text {teachers }}{ }^{2}\end{array}$} & \multicolumn{2}{|c|}{$\begin{array}{c}\text { Elementary and } \\
\text { secondary school } \\
\text { classroom teachers }^{1,2}\end{array}$} & \multicolumn{4}{|c|}{ Average annual salary (current dollars) } \\
\hline & $\begin{array}{c}\text { Instructional } \\
\text { staff }\end{array}$ & $\begin{array}{l}\text { Classroom } \\
\text { teachers }^{1,2}\end{array}$ & & & Males & Females & \begin{tabular}{|c|} 
All \\
Instructional \\
staff $^{3}$
\end{tabular} & $\begin{array}{c}\text { All } \\
\text { classroom } \\
\text { teachers }^{4}\end{array}$ & \begin{tabular}{|} 
Elementary \\
school \\
classroom \\
teachers
\end{tabular} & $\begin{array}{l}\text { Secondary } \\
\text { school } \\
\text { classroom } \\
\text { teachers }\end{array}$ \\
\hline Units & thousands & Thousands & thousands & thousands & thousands & thousands & $\begin{array}{l}\text { current } \\
\text { dollars }\end{array}$ & $\begin{array}{l}\text { current } \\
\text { dollars }\end{array}$ & $\begin{array}{l}\text { current } \\
\text { dollars }\end{array}$ & $\begin{array}{l}\text { current } \\
\text { dollars }\end{array}$ \\
\hline col. no. & (1) & (2) & (3) & (4) & (5) & (6) & (7) & (8) & (9) & (10) \\
\hline $1959-60^{*}$ & 1,464 & 1,355 & (NA) & (NA) & 393 & 962 & 5,174 & 4,995 & 4,815 & 5,276 \\
\hline $1960-61$ & (NA) & 1,408 & 858 & 550 & (NA) & (NA) & (NA) & (NA) & (NA) & (NA) \\
\hline $1961-62$ & 1,588 & 1,458 & (NA) & (NA) & 451 & 1,053 & 5,700 & 5,515 & 5,340 & 5,775 \\
\hline $1962-63$ & (NA) & (NA) & (NA) & (NA) & (NA) & (NA) & (NA) & (NA) & (NA) & (NA) \\
\hline $1963-64$ & 1,717 & 1,568 & (NA) & (NA) & 488 & 1,080 & 6,240 & 5,995 & 5,805 & 6,266 \\
\hline 1964-65 & (NA) & 1,648 & 940 & 708 & (NA) & (NA) & (NA) & (NA) & (NA) & (NA) \\
\hline $1965-66$ & 1,885 & 1,711 & 965 & 746 & 544 & 1,167 & 6,935 & 6,485 & 6,279 & 6,761 \\
\hline $1966-67$ & (NA) & 1,789 & 1,006 & 783 & (NA) & (NA) & (NA) & (NA) & (NA) & (NA) \\
\hline 1967-68 & 2,071 & 1,864 & 1,040 & 815 & 584 & 1,280 & 7,630 & 7,423 & 7,208 & 7,692 \\
\hline 1968-69 & (NA) & (NA) & 1,076 & 860 & (NA) & (NA) & (NA) & (NA) & (NA) & (NA) \\
\hline $1969-70$ & 2,253 & 2,023 & 1,109 & 908 & 690 & 1,333 & 9047 & 8,626 & 8,412 & 8,891 \\
\hline 1970-71 & (NA) & 2,059 & 1,130 & 929 & $676^{6}$ & $1,383^{6}$ & 9698 & 9,268 & 9,021 & 9,568 \\
\hline $1971-72$ & 2,322 & 2,063 & 1,111 & 952 & $688^{6}$ & $1,382^{6}$ & 10,213 & 9,705 & 9,424 & 10,031 \\
\hline 1972-73 & (NA) & 2,106 & 1,142 & 964 & $703^{6}$ & $1,403^{6}$ & 10,634 & 10,174 & 9,893 & 10,507 \\
\hline $1973-74$ & 2,338 & 2,136 & 1,151 & 985 & $715^{6}$ & $1,421^{6}$ & 11,254 & 10,770 & 10,507 & 11,077 \\
\hline 1974-75 & (NA) & 2,165 & 1,166 & 998 & $727^{6}$ & $1,438^{6}$ & 12,167 & 11,641 & 11,334 & 12,000 \\
\hline $1975-76$ & 2,337 & 2198 & 1,181 & 1017 & $742^{6}$ & $1,456^{6}$ & 13,124 & 12,600 & 12,280 & 12,937 \\
\hline 1976-77 & (NA) & 2,189 & 1,168 & 1021 & $734^{6}$ & $1,455^{6}$ & 13,840 & 13,354 & 12,989 & 13,776 \\
\hline 1977-78 & (NA) & 2,209 & 1,185 & 1024 & $742^{6}$ & $1,467^{6}$ & 14,698 & 14,198 & 13,845 & 14,602 \\
\hline 1978-79 & 2,297 & 2,207 & 1,191 & 1016 & $735^{6}$ & $1,472^{6}$ & 15,764 & 15,032 & 14,681 & 15,450 \\
\hline $1979-80$ & (NA) & 2,185 & 1,191 & 994 & $743^{6}$ & $1,442^{6}$ & 16,715 & 15,970 & 15,569 & 16,459 \\
\hline $1980-81$ & 2,860 & 2,184 & 1,189 & 995 & $708^{6}$ & $1,476^{6}$ & 18,404 & 17,644 & 17,230 & 18,142 \\
\hline $1981-82$ & (NA) & 2,127 & 1,183 & 945 & $679^{6}$ & $1,439^{6}$ & 20,327 & 19,274 & 18,853 & 19,805 \\
\hline
\end{tabular}

-55 - 
$<$ CG.A.7> continued

\begin{tabular}{|c|c|c|c|c|c|c|c|c|c|c|}
\hline \multirow[t]{2}{*}{$\begin{array}{l}\text { School } \\
\text { year }\end{array}$} & \multicolumn{2}{|c|}{$\begin{array}{c}\text { Elementary and } \\
\text { secondary schools }\end{array}$} & \multirow{2}{*}{\begin{tabular}{|} 
Elementary \\
school \\
classroom \\
teachers
\end{tabular}} & \multirow{2}{*}{$\begin{array}{l}\text { Secondary } \\
\text { school } \\
\text { classroom }^{\text {teachers }}{ }^{2}\end{array}$} & \multicolumn{2}{|c|}{$\begin{array}{c}\text { Elementary and } \\
\text { secondary school } \\
\text { classroom teachers }^{1,2}\end{array}$} & \multicolumn{4}{|c|}{ Average annual salary (current dollars) } \\
\hline & $\begin{array}{c}\text { Instructional } \\
\text { staff }\end{array}$ & $\begin{array}{l}\text { Classroom } \\
\text { teachers }^{1,2}\end{array}$ & & & Males & Females & \begin{tabular}{|c|} 
All \\
Instructional \\
staff $^{3}$
\end{tabular} & $\begin{array}{c}\text { All } \\
\text { classroom } \\
\text { teachers }^{4}\end{array}$ & \begin{tabular}{|} 
Elementary \\
school \\
classroom \\
teachers
\end{tabular} & $\begin{array}{l}\text { Secondary } \\
\text { school } \\
\text { classroom } \\
\text { teachers }\end{array}$ \\
\hline Units & thousands & thousands & thousands & thousands & thousands & thousands & $\begin{array}{l}\text { current } \\
\text { dollars }\end{array}$ & $\begin{array}{l}\text { current } \\
\text { dollars }\end{array}$ & $\begin{array}{l}\text { current } \\
\text { dollars }\end{array}$ & $\begin{array}{l}\text { current } \\
\text { dollars }\end{array}$ \\
\hline HS no. & H523 & $H 526^{2}$ & new & new & $H 527^{2}$ & $H 528^{2}$ & $H 524^{3}$ & new & new & new \\
\hline col. no. & (1) & (2) & (3) & (4) & (5) & (6) & (7) & (8) & (9) & $(10)$ \\
\hline $1982-83$ & (NA) & 2,133 & 1,182 & 951 & $679^{6}$ & $1,454^{6}$ & 21,641 & 20,695 & 20,227 & 21,291 \\
\hline $1983-84$ & (NA) & 2,139 & 1,186 & 953 & $679^{6}$ & $1,460^{6}$ & 23,005 & 21,935 & 21,487 & 22,554 \\
\hline 1984-85 & $2,692^{\prime}$ & 2,168 & 1,208 & 960 & $679^{6}$ & $1,489^{6}$ & 24,666 & 23,600 & 23,200 & 24,187 \\
\hline $1985-86$ & $2,756^{7}$ & 2,206 & 1,237 & 969 & $669^{6}$ & $1,537^{6}$ & 26,362 & 25,199 & 24,718 & 25,846 \\
\hline 1986-87 & $2,822^{\prime}$ & 2,244 & 1,271 & 973 & $674^{6}$ & $1,570^{6}$ & 27,706 & 26,569 & 26,057 & 27,244 \\
\hline 1987-88 & $2,860^{7}$ & 2,279 & 1,307 & 973 & $665^{6}$ & $1,614^{6}$ & 29,219 & 28,034 & 27,519 & 28,798 \\
\hline 1988-89 & $2,931^{\prime}$ & 2,323 & 1,353 & 970 & $659^{6}$ & $1,664^{6}$ & 30,850 & 29,564 & 29,022 & 30,218 \\
\hline $1989-90$ & $2,986^{7}$ & 2,357 & 1,387 & 970 & $658^{6}$ & $1,699^{6}$ & 32,638 & 31,367 & 30,832 & 32,049 \\
\hline $1990-91$ & $3,051^{7}$ & 2,398 & 1,426 & 972 & $669^{6}$ & $1,728^{6}$ & 34,401 & 33,084 & 32,490 & 33,896 \\
\hline 1991-92 & $3,104^{7}$ & 2,432 & 1,459 & 973 & 679 & 1,753 & 35,556 & 34,063 & 33,479 & 34,827 \\
\hline 1992-93 & $3,140^{\prime}$ & 2,459 & 1,486 & 972 & (NA) & (NA) & 36,460 & 35,029 & 34,350 & 35,880 \\
\hline 1993-94 & $3,209^{\prime}$ & 2,504 & 1,515 & 989 & 679 & 1,825 & 37,441 & 35,733 & 35,233 & 36,555 \\
\hline 1994-95 & $3,285^{\prime}$ & 2,552 & 1,510 & 1,041 & (NA) & (NA) & 38,441 & 36,609 & 36,084 & 37,404 \\
\hline 1995-96 & $(\mathrm{F})$ & 2,586 & 1,529 & 1,058 & (NA) & (NA) & 39,451 & 37,560 & 36,976 & 38,423 \\
\hline $1996-97$ & $(F)$ & 2,679 & 1,576 & 1,103 & (NA) & (NA) & 40,580 & 38,509 & 37,969 & 39,310 \\
\hline
\end{tabular}


Sources: <CG.A.7.1>, 1919-20 to 1969-70, U.S. Bureau of the Census, Historical Statistics of the United States (Washington, D.C.: U.S. G.P.O., 1975), series H 523; 1970-71 to 1994-95, Department of Education, Digest of Education Statistics, annual issues (Washington, D.C.: U.S. G.P.O.); see, for example, 1996 issue, table 81, column 8. <CG.A.7.3>, and <CG.A.7.4>, 1870-1954, Abbott L. Ferris, Indicators of Trends in American Education (N.Y.: Russell Sage Foundation, 1969), series B-5 and B-6; subsequent years from Digest annual issues; see, for example, 1996 issue, table 63, columns 5, 6, and 7. $<$ CG.A.7.2>, <CG.A.7.5>, <CG.A.7.6>, U.S. Department of Education, 120 Years of American Education: A Statistical Portrait (Washington, D.C.: U.S. G.P.O., 1993), table 14. The series rely on Ferris, Indicators, series B-1, B-2, and B-3; U.S. Office of Education, Biennial Survey of Education in the United States; and the Digest, which has been used for updates since 1991. See, especially, Digest of Education Statistics 1996, tables 4 and 63. On rare occasions, the Ferris data have been used in place of those in 120 Years. The sex breakdown is continued in the Digest sporadically after 1990. 〈CG.A.7.7>, 120 Years, table 14, which is from Historical Statistics (1975) to 1968 and from the Digest after 1968. Updated data are from Digest of Education Statistics 1997, table 81. <CG.A.7.8>, <CG.A.7.9>, and $<$ CG.A.7.10>, Digest 1997, table 77.

The instructional staff category includes all public elementary and secondary day-school positions that are concerned with teaching or its improvement, including consultants or supervisors of instruction, principals, teachers, guidance personnel, librarians, psychological personnel, and other instructional staff. The category excludes administrative staff, attendance personnel, clerical personnel, and junior college staff.

Classroom teachers are defined as staff members who instruct pupils in self-contained classes or courses, or in classroom situations. The Schools and Staffing Survey (SASS), first conducted in 1987-88, provides a more precise description of a teacher. For the purposes of SASS, a teacher is any full- or parttime instructor whose primary assignment is to teach in any of the K-12 grades. Beginning in 1993-94, anyone in a school who taught grades K-12 but whose primary assignment was something else (e.g., a principal) was also defined as a teacher. The following individuals were not considered teachers: shortterm substitutes, student teachers, non-teaching specialists (such as guidance counselors, librarians, nurses, and psychologists), administrators, teacher aides, or other professional or support staff. SASS classified teachers as elementary or secondary on the basis of the grades they taught rather than the schools in which they taught. An elementary school teacher was one who, when asked for the grades taught, stated below ninth or ungraded and designated an elementary school teacher. A secondary school teacher was one who, when asked for the grades taught, stated ninth or higher, seventh and higher with no primary assignments at the elementary level, or ungraded and designated as a secondary school teacher. Previous definitions of elementary and secondary teachers are less precise. In most cases, data have been revised to account for teachers in secondary schools (e.g., junior high schools for grades 7 to 9).

Footnotes:

11: For select years prior to 1951-52, includes a small number of librarians and other non-supervisory instructional staff. May not always exactly equal the sum of elementary and secondary teachers, $<$ CG.A.7.3> and <CG.A.7.4>, nor the sum of male and female teachers, <CG.A.7.5> and <CG.A.7.6>. 12: Prior to 1938, number of different persons employed rather than number of positions.

13: Prior to 1919-20, computed for teaching positions only; beginning 1919-20, also includes supervisors and principals. Data for 1980-81 and subsequent years are estimates from the National Education Association.

14: Data for 1970-71 and subsequent years are estimated by the National Education Association.

15: Includes teachers in junior high schools.

16: Estimated figures.

17: Data not comparable with figures prior to 1984. 
$<$ CG.A.9> Public school enrollment by subject in grades nine to twelve: $1889-90$ to $1981-82^{1}$

\begin{tabular}{|c|c|c|c|c|c|c|c|c|c|c|c|c|c|c|c|}
\hline Subject & $\begin{array}{c}1889- \\
90^{2} \\
\end{array}$ & $\begin{array}{l}1899- \\
1900^{2}\end{array}$ & $\begin{array}{c}1909- \\
10\end{array}$ & $\begin{array}{c}1914- \\
15 \\
\end{array}$ & $\begin{array}{c}1921- \\
22\end{array}$ & $\begin{array}{c}1927- \\
28\end{array}$ & $\begin{array}{c}1933- \\
34\end{array}$ & $\begin{array}{c}1948- \\
49\end{array}$ & $\begin{array}{l}1954- \\
55^{3}\end{array}$ & $\begin{array}{c}1958- \\
59^{3}\end{array}$ & $\begin{array}{c}1960- \\
61\end{array}$ & $\begin{array}{c}1962- \\
63^{3}\end{array}$ & $\begin{array}{c}1964- \\
65\end{array}$ & $\begin{array}{c}1972- \\
73^{3}\end{array}$ & $\begin{array}{c}1981- \\
82\end{array}$ \\
\hline Units & $\%$ & $\%$ & $\%$ & $\%$ & $\%$ & $\%$ & $\%$ & $\%$ & $\%$ & $\%$ & $\%$ & $\%$ & $\%$ & $\%$ & $\%$ \\
\hline col no. & (1) & (2) & (3) & (4) & (5) & (6) & (7) & (8) & (9) & (10) & (11) & (12) & (13) & (14) & (15) \\
\hline \multicolumn{16}{|c|}{ Physical and biological sciences } \\
\hline Biology ${ }^{4}$ & $(\mathrm{NA})$ & $(\mathrm{NA})$ & 23.8 & 19.3 & 14.1 & 15.9 & 16.1 & 18.6 & 20.0 & 20.8 & 21.7 & 24.0 & 23.2 & 18.6 & 24.1 \\
\hline General science & (NA) & $(\mathrm{NA})$ & $(\mathrm{NA})$ & (NA) & 18.3 & 17.5 & 17.8 & 20.8 & (NA) & 19.6 & 22.2 & 17.6 & 18.7 & 11.3 & 23 \\
\hline Chemistry & 10.1 & 7.7 & 6.9 & 7.4 & 7.4 & 7.1 & 7.6 & 7.6 & 7.5 & 8.1 & 9.1 & 8.3 & 9.3 & 8.7 & 9.8 \\
\hline Physiology & $(\mathrm{NA})$ & 27.4 & 15.3 & 9.5 & 5.2 & 2.7 & 1.8 & 1.0 & $(\mathrm{NA})$ & (NA) & 0.8 & $(\mathrm{NA})$ & $(\mathrm{NA})$ & 0.9 & 1.2 \\
\hline Physics & 22.2 & 19.0 & 14.6 & 14.2 & 8.9 & 6.9 & 6.3 & 5.4 & 4.7 & 4.7 & 4.9 & 3.8 & 4.5 & 2.9 & 1.0 \\
\hline Earth science $^{5}$ & (NA) & 29.8 & 21.0 & 15.3 & 4.5 & 2.8 & 1.8 & 0.4 & (NA) & (NA) & 0.9 & (NA) & (NA) & 3.8 & 0.7 \\
\hline \multicolumn{16}{|c|}{ Mathematics } \\
\hline Algebra & 45.4 & 56.3 & 56.9 & 48.8 & 40.2 & 35.2 & 30.4 & 26.8 & 25.3 & 29.9 & 28.6 & 30.4 & 28.5 & 19.7 & 29.5 \\
\hline General mathematics $^{6}$ & (NA) & (NA) & (NA) & (NA) & 12.4 & 7.9 & 7.4 & 13.1 & 12.3 & 12.7 & 17.4 & 11.7 & 15.4 & 13.8 & 21.7 \\
\hline Geometry & 21.3 & 27.4 & 30.9 & 26.6 & 22.7 & 19.8 & 17.1 & 12.8 & 12.5 & 13.4 & 13.8 & 14.7 & 13.9 & 11.6 & 11.4 \\
\hline Trigonometry & (NA) & 1.9 & 1.9 & 1.5 & 1.5 & 1.3 & 1.3 & 2.0 & 2.6 & 2.7 & 3.0 & 2.0 & 2.0 & 6.2 & 3.5 \\
\hline \multicolumn{16}{|c|}{ Languages and literature } \\
\hline English' $^{\prime}$ & $(\mathrm{NA})$ & 42.1 & 57.1 & 55.8 & 78.6 & 93.1 & 90.5 & 92.9 & (NA) & (NA) & 94.6 & $(\mathrm{NA})$ & $(\mathrm{NA})$ & 89.8 & 86.5 \\
\hline Rhetoric $^{\prime}$ & (NA) & 38.5 & 57.1 & 58.4 & (NA) & (NA) & (NA) & (NA) & (NA) & (NA) & $(\mathrm{NA})$ & (NA) & $(\mathrm{NA})$ & (NA) & $(\mathrm{NA})$ \\
\hline Spanish & (NA) & $(\mathrm{NA})$ & 0.7 & 2.4 & 11.3 & 9.4 & 6.2 & 8.2 & (NA) & (NA) & 9.8 & (NA) & 14.5 & 12.3 & 12.3 \\
\hline French & 5.8 & 7.8 & 9.9 & 8.8 & 15.5 & 14.0 & 10.9 & 4.7 & (NA) & (NA) & 8.0 & (NA) & 12.4 & 7.6 & 6.6 \\
\hline German & 10.5 & 14.3 & 23.7 & 24.4 & 0.7 & 1.8 & 2.4 & 0.8 & (NA) & (NA) & 1.7 & (NA) & 2.7 & 3.1 & 2.1 \\
\hline Latin & 34.7 & 50.6 & 49.1 & 37.3 & 27.5 & 22.0 & 16.0 & 7.8 & (NA) & $(\mathrm{NA})$ & 7.8 & (NA) & (NA) & 1.5 & 1.1 \\
\hline Other foreign languages $^{8}$ & 3.1 & 2.9 & 0.8 & 0.3 & 0.1 & 0.1 & 0.2 & 0.3 & (NA) & (NA) & 0.3 & (NA) & $(\mathrm{NA})$ & 0.3 & 0.3 \\
\hline \multicolumn{16}{|c|}{ History and social sciences } \\
\hline History $^{9}$ & 27.31 & 38.16 & 55.0 & 50.5 & 50.7 & 46.5 & 42.7 & 42.7 & (NA) & (NA) & 44.4 & (NA) & $(\mathrm{NA})$ & 46.3 & 44.7 \\
\hline Civics and government ${ }^{10}$ & $(\mathrm{NA})$ & 21.66 & 15.6 & 15.7 & 19.3 & 21.1 & 19.8 & 13.2 & (NA) & (NA) & 23.0 & (NA) & (NA) & 15.2 & 18.7 \\
\hline${ }$ ther social sciences ${ }^{11}$ & (NA) & 2.38 & 1.0 & 1.2 & 8.1 & 8.8 & 7.7 & 15.3 & (NA) & (NA) & 16.0 & (NA) & (NA) & 20.0 & 29.8 \\
\hline All academic subjects & (NA) & $(\mathrm{NA})$ & 417.2 & 378.2 & 332.8 & 317.9 & 287.9 & 275.8 & (NA) & (NA) & 306.3 & (NA) & (NA) & 275.0 & 303.9 \\
\hline
\end{tabular}


$<$ CG.A.9> continued

\begin{tabular}{|c|c|c|c|c|c|c|c|c|c|c|c|c|c|c|c|}
\hline Subject & $\begin{array}{c}1889- \\
90^{2}\end{array}$ & $\begin{array}{l}1899- \\
1900^{2}\end{array}$ & $\begin{array}{c}1909- \\
10\end{array}$ & $\begin{array}{c}1914- \\
15\end{array}$ & $\begin{array}{c}1921- \\
22\end{array}$ & $\begin{array}{c}1927- \\
28\end{array}$ & $\begin{array}{c}1933- \\
34\end{array}$ & $\begin{array}{c}1948- \\
49\end{array}$ & $\begin{array}{c}1954- \\
55^{3}\end{array}$ & $\begin{array}{c}1958- \\
59^{3}\end{array}$ & $\begin{array}{c}1960- \\
61\end{array}$ & $\begin{array}{c}1962- \\
63^{3}\end{array}$ & $\begin{array}{c}1964- \\
65\end{array}$ & $\begin{array}{c}1972- \\
73^{3}\end{array}$ & $\begin{array}{c}1981- \\
82\end{array}$ \\
\hline Units & $\%$ & $\%$ & $\%$ & $\%$ & $\%$ & $\%$ & $\%$ & $\%$ & $\%$ & $\%$ & $\%$ & $\%$ & $\%$ & $\%$ & $\%$ \\
\hline col no. & (1) & (2) & (3) & (4) & (5) & (6) & (7) & (8) & (9) & (10) & (11) & (12) & (13) & (14) & (15) \\
\hline \multicolumn{16}{|c|}{ Industrial and commercial subjects } \\
\hline Typewriting & (NA) & (NA) & (NA) & (NA) & 13.1 & 15.2 & 16.7 & 22.5 & (NA) & (NA) & 23.2 & (NA) & (NA) & 20.3 & 21 \\
\hline Industrial subjects ${ }^{12}$ & (NA) & (NA) & (NA) & 11.2 & 13.7 & 13.5 & 21.0 & 26.6 & (NA) & (NA) & 28.0 & (NA) & (NA) & 3.7 & 14.8 \\
\hline Bookkeeping & $(\mathrm{NA})$ & (NA) & (NA) & 3.4 & 12.6 & 10.7 & 9.9 & 8.7 & (NA) & (NA) & 7.7 & (NA) & $(\mathrm{NA})$ & 5.8 & 3.2 \\
\hline Shorthand & (NA) & (NA) & (NA) & (NA) & 8.9 & 8.7 & 9.0 & 7.8 & (NA) & $(\mathrm{NA})$ & 6.7 & (NA) & (NA) & 4.6 & 3.1 \\
\hline Other business subjects ${ }^{13}$ & (NA) & (NA) & (NA) & (NA) & 5.4 & 13.7 & 16.9 & 14.5 & (NA) & (NA) & 10.0 & (NA) & $(\mathrm{NA})$ & 9.9 & 12.3 \\
\hline \multicolumn{16}{|c|}{ Other subjects, generally non-academic } \\
\hline Physical education & (NA) & (NA) & (NA) & (NA) & 5.7 & 15.0 & 50.7 & 69.4 & $(\mathrm{NA})$ & $(\mathrm{NA})$ & 73.8 & (NA) & (NA) & 56.9 & 59 \\
\hline $\mathrm{Art}^{12}$ & (NA) & (NA) & (NA) & 22.9 & 14.7 & 11.7 & 8.7 & 9.0 & (NA) & (NA) & 19.3 & (NA) & (NA) & 17.9 & 24.2 \\
\hline Home economics & (NA) & (NA) & 3.8 & 12.9 & 14.3 & 16.5 & 16.7 & 24.2 & (NA) & $(\mathrm{NA})$ & 23.1 & (NA) & (NA) & 20.4 & 23.9 \\
\hline Music & (NA) & (NA) & (NA) & 31.5 & 25.4 & 26.0 & 25.5 & 30.1 & (NA) & (NA) & 28.0 & (NA) & (NA) & 25.1 & 21.6 \\
\hline Agriculture & (NA) & (NA) & 4.7 & 7.2 & 5.1 & 3.7 & 3.6 & 6.7 & (NA) & (NA) & 6.2 & (NA) & (NA) & 2.7 & 3.3 \\
\hline Miscellaneous $^{14}$ & (NA) & (NA) & (NA) & (NA) & 7.0 & 8.4 & 9.5 & 6.5 & (NA) & (NA) & 7.2 & (NA) & (NA) & 30.0 & 20.1 \\
\hline All subjects & (NA) & (NA) & 425.7 & 467.2 & 458.7 & 461.0 & 475.9 & 501.8 & (NA) & (NA) & 539.4 & (NA) & (NA) & 472.3 & 510.4 \\
\hline
\end{tabular}


Sources: <CG.A.9.1>, Annual Report of the Commissioner of Education, 1890, p. 1392; <CG.A.9.2>, Annual Report of the Commissioner of Education, 1900, tables 10 and 11, pp. 2138-39; <CG.A.9.3>, Annual Report of the Commissioner of Education, 1910, tables 138, 139 and 140, pp. 1182-84; 〈CG.A.9.4〉, Annual Report of the Commissioner of Education, 1916, tables 34, 47, 48, 49 and 50, p. 487 and p. 500; <CG.A.9.5>, U.S. Office of Education, Biennial Survey of Education in the United States, 1920-22, table 34, p. 599; <CG.A.9.6>, U.S. Office of Education, Biennial Survey of Education in the United States, 1926-28, tables 59 and 61, pp. 1057-60; $<$ CG.A.9.7>, U.S. Office of Education, Biennial Survey of Education in the United States, 1936-38, table 24, p. 24; $<$ CG.A.9.8>, U.S. Office of Education, Biennial Survey of Education in the United States, 1948-50, tables 5 and 7 ,

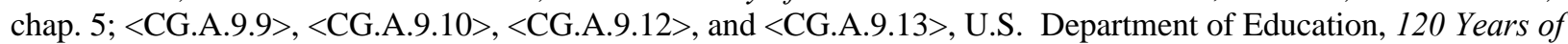
American Education: A Statistical Portrait (Washington, D.C.: U.S. G.P.O., 1993), table 16; <CG.A.9.11>, U.S. Department of Health, Education and Welfare, Office of Education, Subject Offerings and Enrollments in Public Secondary Schools, 1965, table 7; <CG.A.9.14> and 〈CG.A.9.15>, U.S. Department of Education, National Center for Education Statistics, A Trend Study of High School Offerings and Enrollments: 1972-73 and 1981-82 (Washington, D.C.: U.S. G.P.O., 1984), tables 1 and 2.

All series are based on surveys of schools requested by the U.S. Commissioner of Education or the Department (Office) of Education. However, the collection of these data changed over the years. For <CG.A.9.3> through $<$ CG.A.9.7>, the percentages are based on the number of pupils enrolled in the last four years of all schools that returned usable questionnaires. For subsequent years, the figures are based on the total number of pupils enrolled in the last four years of all schools. Thus, starting with <CG.A.9.8> schools were sampled and the results were then weighted to approximate the percentages taking specific subjects in all public secondary schools.

The caution noted in the Biennial, 1948-50, p. 5, is worth repeating: "Obviously special caution should be used in drawing conclusions ... Because subjects are represented ... only as they have from time to time been judged important in the number of their enrollments, many desirable details are missing. It is possible to do little more than trace the broad outlines of most changes which have occurred. Percentage enrollments in the different investigations reported in the historical table are not precisely comparable. Beginning with 1910 and until the present investigation, the percentage of pupils in each subject is based upon the number of pupils in the schools reporting subject enrollments." By implication, then, the percentages for $\langle$ CG.A.9.1 $>$ and $\langle$ CG.A.9.2 $\rangle$ are based on all students in grades nine through twelve. These two series may, therefore, seriously understate the percentages taking various courses of study because the denominator may include those in schools responding incompletely or not at all.

In all years, the percentages are intended to give the number of pupils, in grades nine to twelve, taking specific courses of study during the school year divided by the total number of pupils in those grades. Information was not given concerning whether the subjects listed were semester or full-year courses. Some were clearly full-year courses, others were probably semester courses, yet others may have been half-semester in length. If all courses of study were full-year the "all subjects" totals, for $\langle$ CG.A.9.3 $\rangle$ to $\langle$ CG.A.9.15> (excluding the four incomplete years), ranging from about 450 and 550, imply that pupils in grades nine to twelve were taking about five full-year courses each year.

Prior versions of this table (see, for example, 120 Years, table 16) aggregated various subjects and omitted others. The reasons are given in the source for the revised data (Biennial Survey, 1948-50): "when necessary, the subjects reported in previous surveys were analyzed, and appropriate components were either recombined, separately listed, or eliminated (with corresponding changes in the number and percentage enrolled) in a manner to yield as close comparability as possible with the data in the current (1948-49) survey." In constructing this table, the original sources were used to obtain greater detail and more accurately reflect changes in curriculum over time. However, there are cases in which the procedure will overstate the number of full-year courses taken. See 17 regarding English. With regard to history, see 19. By adding together various other history courses, the percentage taking history may be overstated if students took history courses covering English history and modern history, for example. Previous versions of this table aggregated only U.S. history and English history to form the history group.

Subjects surveyed were intended to include only those for which secondary school credit was given and to exclude extracurricular activities. The large increase in the percentage taking physical education between 1927-28 and 1933-34 may represent a change in the category rather than an increase in the activity. 
Footnotes:

11: Percentages may not add up to totals because of rounding. Subjects in each group are in descending order relative to <CG.A.9.15>.

12: See series note concerning undercounts.

13: Incomplete listing of subjects in original source.

14: Includes botany and zoology.

15: For <CG.A.9.1 > to <CG.A.9.7>, physical geography, astronomy, and geology were reported separately, but subsequently were combined under the heading of earth science. Earth science for <CG.A.9.14> and <CG.A.9.15> also includes geology and astronomy. The subject geography, which appears after 1948, is included in "other social sciences."

16: Includes arithmetic, business arithmetic, and general mathematics, not all of which are listed in each year.

17: For <CG.A.9.2> to <CG.A.9.4>, enrollments in English (termed English literature) and rhetoric were listed separately. In 1909-10 and 1914-15, the combined enrollments in these two subjects was 114 percent of the total enrollment and many students were probably taking the two subjects as a part of one course. In 1922, the U.S. Office of Education attempted to collect enrollments in the various English subjects, but it became necessary to combine them all under the heading "English." The Office of Education reported that, in 1921-22, 78.6 percent of the pupils in schools reporting enrollment by subject (excluding duplicates) were taking one or more English subjects. The implication, therefore, is that about half of the students previously listed as taking both English literature and rhetoric were taking them as part of the same course. English literature and rhetoric enrollments are not available for $\langle$ CG.A.9.1 $>$.

18: Includes Greek, Russian, and Italian.

19: Includes U.S., English, world, ancient, medieval, and modern history.

110: Includes "problems of democracy."

11: Includes geography, sociology, economics, consumer education, and psychology.

12: Original sources for <CG.A.9.4> to <CG.A.9.7> give higher numbers for art and lower numbers for industrial subjects than in the revised estimates in Biennial Survey, 1948-50. It is likely that the subject of draftsmanship was shifted from art to industrial subjects.

113: Includes business English, business law, commercial geography, commercial history, penmanship, office practice, elementary business training, retailing, cooperative store training, cooperative office training, and salesmanship and advertising. Some of the subjects contained enrollments throughout the years, although some disappeared. The group as a whole, however, appears to reflect an interest in business and commercial subjects that was steady, but subject to compositional change.

114: Includes teacher training, journalism, speech and public speaking, hygiene and sanitation, and safety and driver's education. 
<CG.A.11> High school graduates, by sex and control of institution: 1870 to 1997

\begin{tabular}{|c|c|c|c|c|c|c|c|}
\hline \multirow{3}{*}{$\begin{array}{l}\text { School } \\
\text { year } \\
\text { ending }\end{array}$} & \multicolumn{5}{|c|}{ High school graduates } & \multirow{3}{*}{\begin{tabular}{|c|} 
Population \\
17 years \\
old
\end{tabular}} & \multirow{3}{*}{$\begin{array}{l}\text { Public and private } \\
\text { high school } \\
\text { graduates per } 100 \\
17 \text {-year olds }\end{array}$} \\
\hline & \multirow[t]{2}{*}{ Total $^{1}$} & \multicolumn{2}{|c|}{$\operatorname{Sex}^{2}$} & \multicolumn{2}{|c|}{ Control $^{3}$} & & \\
\hline & & Male & Female & Public & Private & & \\
\hline Units & thousands & thousands & thousands & thousands & thousands & thousands & percentage \\
\hline HS no. & H598 & $\mathrm{H} 600$ & $H 601$ & new & new & new & H599 \\
\hline col. no. & (1) & (2) & (3) & (4) & (5) & (6) & (7) \\
\hline 1870 & 16 & 7 & 9 & $\begin{array}{ll}--- \\
\end{array}$ & ---- & 815 & 2 \\
\hline 1871 & 17 & 7 & 9 & ---- & ---- & $(\mathrm{NA})$ & (NA) \\
\hline 1872 & 17 & 8 & 10 & ---- & $\begin{array}{ll}--- \\
\end{array}$ & $(\mathrm{NA})$ & (NA) \\
\hline 1873 & 18 & 8 & 10 & ---- & ---- & (NA) & (NA) \\
\hline 1874 & 19 & 8 & 11 & $\begin{array}{ll}--- \\
\end{array}$ & $\begin{array}{ll}--- \\
\end{array}$ & (NA) & $(\mathrm{NA})$ \\
\hline 1875 & 20 & 9 & 11 & ---- & ---- & (NA) & (NA) \\
\hline 1876 & 20 & 9 & 11 & ---- & $-\cdots-$ & $(\mathrm{NA})$ & (NA) \\
\hline 1877 & 21 & 9 & 11 & ---- & ---- & (NA) & (NA) \\
\hline 1878 & 22 & 10 & 12 & ---- & ---- & (NA) & (NA) \\
\hline 1879 & 23 & 10 & 13 & ---- & ---- & (NA) & (NA) \\
\hline 1880 & 24 & 11 & 13 & ---- & ---- & 946 & 3 \\
\hline 1881 & 25 & 11 & 14 & ---- & ---- & (NA) & (NA) \\
\hline 1882 & 27 & 12 & 15 & ---- & ---- & (NA) & (NA) \\
\hline 1883 & 28 & 13 & 16 & ---- & ---- & (NA) & (NA) \\
\hline 1884 & 31 & 14 & 17 & ---- & ---- & (NA) & (NA) \\
\hline 1885 & 32 & 14 & 18 & ---- & ---- & $(\mathrm{NA})$ & (NA) \\
\hline 1886 & 33 & 15 & 18 & ---- & ---- & (NA) & (NA) \\
\hline 1887 & 32 & 14 & 18 & ---- & ---- & (NA) & (NA) \\
\hline 1888 & 33 & 14 & 19 & ---- & ---- & (NA) & (NA) \\
\hline 1889 & 39 & 16 & 22 & ---- & ---- & (NA) & (NA) \\
\hline 1890 & 44 & 19 & 25 & ---- & ---- & 1,259 & 3 \\
\hline 1891 & 48 & 20 & 28 & ---- & ---- & (NA) & (NA) \\
\hline 1892 & 53 & 21 & 32 & ---- & ---- & (NA) & (NA) \\
\hline 1893 & 59 & 24 & 35 & ---- & ---- & (NA) & (NA) \\
\hline 1894 & 65 & 27 & 39 & ---- & ---- & (NA) & (NA) \\
\hline 1895 & 72 & 29 & 43 & ---- & ---- & (NA) & (NA) \\
\hline 1896 & 76 & 31 & 45 & ---- & ---- & $(\mathrm{NA})$ & (NA) \\
\hline 1897 & 80 & 32 & 47 & ---- & ---- & (NA) & (NA) \\
\hline 1898 & 84 & 34 & 50 & ---- & ---- & (NA) & (NA) \\
\hline 1899 & 90 & 36 & 53 & ---- & ---- & (NA) & (NA) \\
\hline 1900 & 95 & 38 & 57 & ---- & ---- & 1,489 & 6 \\
\hline 1901 & 97 & 37 & 60 & --- & --- & (NA) & (NA) \\
\hline 1902 & 99 & 39 & 61 & ---- & ---- & (NA) & (NA) \\
\hline 1903 & 105 & 41 & 64 & ---- & ---- & (NA) & (NA) \\
\hline 1904 & 112 & 44 & 68 & --- & ---- & (NA) & (NA) \\
\hline 1905 & 119 & 47 & 72 & ---- & ---- & (NA) & (NA) \\
\hline 1906 & 126 & 50 & 76 & ---- & ---- & (NA) & (NA) \\
\hline 1907 & 127 & 51 & 76 & ---- & ---- & (NA) & (NA) \\
\hline 1908 & 129 & 52 & 77 & ---- & ---- & (NA) & (NA) \\
\hline 1909 & 142 & 57 & 84 & ---- & ---- & $(\mathrm{NA})$ & (NA) \\
\hline
\end{tabular}




\begin{tabular}{|c|c|c|c|c|c|c|c|}
\hline \multirow{3}{*}{$\begin{array}{l}\text { School } \\
\text { year } \\
\text { ending }\end{array}$} & \multicolumn{5}{|c|}{ High school graduates } & \multirow{3}{*}{$\begin{array}{l}\text { Population } \\
17 \text { years } \\
\text { old }\end{array}$} & \multirow{3}{*}{$\begin{array}{l}\text { Public and private } \\
\text { high school } \\
\text { graduates per } 100 \\
\text { 17-year olds }\end{array}$} \\
\hline & \multirow[t]{2}{*}{ Total $^{1}$} & \multicolumn{2}{|c|}{$\operatorname{Sex}^{2}$} & \multicolumn{2}{|c|}{ Control $^{3}$} & & \\
\hline & & Male & Female & Public & Private & & \\
\hline Units & thousands & thousands & thousands & thousands & thousands & thousands & percentage \\
\hline HS no. & H598 & $\mathrm{H} 600$ & $H 601$ & new & new & new & H599 \\
\hline col. no. & (1) & (2) & (3) & (4) & (5) & (6) & (7) \\
\hline 1910 & 156 & 64 & 93 & 123 & 33 & $1,814^{5}$ & 9 \\
\hline 1911 & 168 & 69 & 99 & 133 & 35 & 1,823 & 9 \\
\hline 1912 & 181 & 74 & 106 & (NA) & (NA) & 1,832 & 10 \\
\hline 1913 & 200 & 82 & 117 & 163 & 37 & 1,842 & 11 \\
\hline 1914 & 219 & 90 & 129 & 180 & 39 & 1,851 & 12 \\
\hline 1915 & 240 & 99 & 140 & $(\mathrm{NA})$ & (NA) & 1,860 & 13 \\
\hline 1916 & 259 & 108 & 151 & 220 & 39 & 1,870 & 14 \\
\hline 1917 & 272 & 110 & 162 & (NA) & (NA) & 1,879 & 14 \\
\hline 1918 & 285 & 112 & 173 & 245 & 40 & 1,889 & 15 \\
\hline 1919 & 298 & 118 & 180 & (NA) & (NA) & 1,898 & 16 \\
\hline 1920 & 311 & 124 & 188 & 268 & 43 & $1,908^{5}$ & 16 \\
\hline 1921 & 334 & 137 & 198 & (NA) & (NA) & 1,944 & 17 \\
\hline 1922 & 357 & 150 & 207 & 313 & 44 & 1,980 & 18 \\
\hline 1923 & 426 & 181 & 244 & (NA) & (NA) & 2,017 & 21 \\
\hline 1924 & 494 & 213 & 281 & 437 & 57 & 2,055 & 24 \\
\hline 1925 & 528 & 230 & 298 & (NA) & (NA) & 2,093 & 25 \\
\hline 1926 & 561 & 246 & 315 & 495 & 66 & 2,132 & 26 \\
\hline 1927 & 579 & 256 & 323 & (NA) & (NA) & 2,172 & 27 \\
\hline 1928 & 597 & 266 & 330 & 533 & 64 & 2,213 & 27 \\
\hline 1929 & 632 & 283 & 349 & (NA) & (NA) & 2,254 & 28 \\
\hline 1930 & 667 & 300 & 367 & 599 & 68 & 2,296 & 29 \\
\hline 1931 & 747 & 337 & 409 & (NA) & (NA) & 2,327 & 32 \\
\hline 1932 & 827 & 375 & 452 & 747 & 80 & 2,330 & 35 \\
\hline 1933 & 871 & 403 & 468 & (NA) & (NA) & 2,335 & 37 \\
\hline 1934 & 915 & 432 & 483 & 843 & 72 & 2,334 & 39 \\
\hline 1935 & 965 & 459 & 506 & (NA) & (NA) & 2,348 & 41 \\
\hline 1936 & 1,015 & 486 & 530 & 941 & 74 & 2,377 & 43 \\
\hline 1937 & 1,068 & 505 & 563 & (NA) & (NA) & 2,416 & 44 \\
\hline 1938 & 1,120 & 524 & 596 & 1,039 & 81 & 2,456 & 46 \\
\hline 1940 & 1,221 & 579 & 643 & 1,136 & 85 & 2,403 & 51 \\
\hline 1942 & 1,242 & 577 & 666 & (NA) & (NA) & 2,421 & 51 \\
\hline 1944 & 1,019 & 424 & 595 & (NA) & (NA) & 2,386 & 43 \\
\hline 1946 & 1,080 & 467 & 613 & (NA) & (NA) & 2,278 & 47 \\
\hline 1948 & 1,190 & 563 & 627 & 1,073 & 117 & 2,261 & 53 \\
\hline 1950 & 1,200 & 571 & 629 & 1,063 & 136 & 2,034 & 59 \\
\hline 1952 & 1,197 & 569 & 627 & 1,056 & 141 & 2,086 & 57 \\
\hline 1954 & 1,276 & 613 & 664 & 1,129 & 147 & 2,135 & 60 \\
\hline 1956 & 1,415 & 680 & 735 & 1,252 & 163 & 2,242 & 63 \\
\hline 1957 & 1,434 & 690 & 744 & 1,270 & 164 & 2,272 & 63 \\
\hline
\end{tabular}


<CG.A.11> continued

\begin{tabular}{|c|c|c|c|c|c|c|c|}
\hline \multirow{3}{*}{$\begin{array}{l}\text { School } \\
\text { year } \\
\text { ending }\end{array}$} & \multicolumn{5}{|c|}{ High school graduates } & \multirow{3}{*}{$\begin{array}{c}\text { Population } \\
17 \text { years } \\
\text { old }\end{array}$} & \multirow{3}{*}{$\begin{array}{l}\text { Public and private } \\
\text { high school } \\
\text { graduates per } 100 \\
\text { 17-year olds }\end{array}$} \\
\hline & \multirow[t]{2}{*}{ Total $^{1}$} & \multicolumn{2}{|c|}{$\operatorname{Sex}^{2}$} & \multicolumn{2}{|c|}{ Control $^{3}$} & & \\
\hline & & Male & Female & Public & Private & & \\
\hline Units & thousands & thousands & thousands & thousands & thousands & thousands & percentage \\
\hline HS no. & H598 & $\mathrm{H} 600$ & $H 601$ & new & new & new & H599 \\
\hline col. no. & (1) & (2) & (3) & (4) & (5) & (6) & (7) \\
\hline 1958 & 1,506 & 725 & 781 & 1,332 & 174 & 2,325 & 65 \\
\hline 1959 & 1,627 & 784 & 843 & 1,435 & 192 & 2,458 & 66 \\
\hline 1960 & 1,858 & 895 & 963 & 1,627 & 231 & 2,672 & 70 \\
\hline 1961 & 1,964 & 955 & 1,009 & 1,725 & 239 & 2,892 & 68 \\
\hline 1962 & 1,918 & 938 & 980 & 1,678 & 240 & $2,768^{6}$ & 69 \\
\hline 1963 & 1,943 & 956 & 987 & 1,710 & 233 & $2,740^{6}$ & $71^{6}$ \\
\hline 1964 & 2,283 & 1,120 & 1,163 & 2,008 & 275 & $2,978^{6}$ & $77^{6}$ \\
\hline 1965 & 2,658 & 1,311 & 1,347 & 2,360 & 298 & $3,684^{6}$ & $72^{6}$ \\
\hline 1966 & 2,665 & 1,323 & 1,342 & 2,367 & 298 & $3,489^{6}$ & $76^{6}$ \\
\hline 1967 & 2,672 & 1,328 & 1,344 & 2,374 & 298 & 3,500 & 76 \\
\hline 1968 & 2,695 & 1,338 & 1,357 & 2,395 & 300 & 3,532 & 76 \\
\hline 1969 & 2,822 & 1,399 & 1,423 & 2,522 & 300 & 3,659 & 77 \\
\hline 1970 & 2,889 & 1,430 & 1,459 & 2,589 & 300 & 3,757 & 77 \\
\hline 1971 & 2,937 & 1,454 & 1,483 & 2,638 & 300 & 3,872 & 76 \\
\hline 1972 & 3,001 & 1,487 & 1,514 & 2,700 & 302 & 3,973 & 76 \\
\hline 1973 & 3,036 & 1,500 & 1,536 & 2,729 & 306 & 4,049 & 75 \\
\hline 1974 & 3,073 & 1,512 & 1,561 & 2,763 & 310 & 4,132 & 74 \\
\hline 1975 & 3,133 & 1,542 & 1,591 & 2,823 & 310 & 4,256 & 74 \\
\hline 1976 & 3,148 & 1,552 & 1,596 & 2,837 & 311 & 4,272 & 74 \\
\hline 1977 & 3,152 & 1,548 & 1,604 & 2,837 & 315 & 4,272 & 74 \\
\hline 1978 & 3,127 & 1,531 & 1,596 & 2,825 & 302 & 4,286 & 73 \\
\hline 1979 & 3,101 & 1,517 & 1,584 & 2,801 & 300 & 4,327 & 72 \\
\hline 1980 & 3,043 & 1,491 & 1,552 & 2,748 & 295 & 4,262 & 71 \\
\hline 1981 & 3,020 & 1,483 & 1,537 & 2,725 & 295 & 4,212 & 72 \\
\hline 1982 & 2,995 & 1,471 & 1,524 & 2,705 & 290 & 4,134 & 72 \\
\hline 1983 & 2,888 & 1,437 & 1,451 & 2,598 & 290 & 3,962 & 73 \\
\hline 1984 & $2,767^{\prime}$ & $1,313^{\prime}$ & 1,454 & 2,495 & 272 & 3,784 & 73 \\
\hline 1985 & $2,677^{7}$ & $1,291^{7}$ & 1,386 & 2,414 & 263 & 3,699 & 72 \\
\hline 1986 & $2,643^{7}$ & $1,263^{7}$ & 1,380 & 2,383 & 260 & 3,670 & 72 \\
\hline 1987 & $2,694^{\prime}$ & $1,301^{\prime}$ & 1,393 & 2,429 & 265 & 3,754 & 72 \\
\hline 1988 & $2,773^{7}$ & $1,384^{7}$ & 1,389 & 2,500 & 273 & 3,849 & 72 \\
\hline 1989 & $2,727^{7}$ & $1,343^{7}$ & 1,384 & 2,459 & 268 & 3,842 & 71 \\
\hline 1990 & $2,586^{\prime}$ & $1,285^{\prime}$ & 1,302 & 2,320 & 266 & 3,574 & 72 \\
\hline 1991 & $2,503^{7}$ & $1,257^{7}$ & 1,254 & 2,235 & 268 & 3,417 & 73 \\
\hline 1992 & 2,482 & (NA) & (NA) & 2,226 & 256 & 3,381 & 73 \\
\hline 1993 & 2,490 & (NA) & (NA) & 2,233 & 257 & 3,433 & 73 \\
\hline 1994 & 2,479 & (NA) & (NA) & 2,221 & 258 & 3,442 & 72 \\
\hline 1995 & 2,531 & (NA) & (NA) & 2,274 & 257 & 3,571 & 71 \\
\hline 1996 & 2,557 & (NA) & (NA) & 2,293 & 264 & 3,629 & 70 \\
\hline 1997 & 2,623 & (NA) & (NA) & 2,358 & 265 & 3,762 & 70 \\
\hline
\end{tabular}


Sources:

<CG.A.11.1>, 1870-1930, U.S. Bureau of the Census, Historical Statistics of the United States (Washington, D.C.: U.S. G.P.O., 1975) series H 598, for which the original source is U.S. Office of Education, Statistical Summary of Education, 1937-38, table 15; 1931-1976, U.S. Department of Education, 120 Years of American Education: A Statistical Portrait (Washington, D.C.: U.S. G.P.O., 1993), table 19, the underlying sources of which are: 1931-38, Statistical Summary, table 15; 1940-52, U.S. Office of Education, Biennial Survey of Education in the United States; 1954-70, Projections of Educational Statistics; and 1971-1976, U.S. Department of Education, Digest of Education Statistics, annual issues (Washington, D.C.: U.S. G.P.O.); 1977-1997, U.S. Department of Education, Digest of Education Statistics 1997 (Washington, D.C.: U.S. G.P.O., 1997), table 99. 〈CG.A.11.2〉, and 〈CG.A.11.3〉, 18701930, Historical Statistics (1975), series H 600 and H 601, for which the original source is U.S. Office of Education, Statistical Summary of Education, 1937-38, table 15; 1931-1976 and 1984-1991, 120 Years of American Education (1993), table 19 for which the original sources are the same as for <CG.A.11.1> to 1976; 1977-1983: Digest of Education Statistics 1997 (1997), table 99.

<CG.A.11.4> and <CG.A.11.5>, 1910-1940, for sources see discussion in Claudia Goldin, "America's Graduation from High School: The Evolution and Spread of Secondary Schooling in the Twentieth Century," Journal of Economic History 58 (June 1998), pp. 345-74; the public and private breakdown implicit in the Goldin data are applied to the total in <CG.A.11.1>. Goldin's estimates are derived from the same data as are the official estimates and differences between the official estimates of all high school graduates and those in Goldin are small (1910, $0.8 \% ; 1920,0.3 \% ; 1930,1.4 \%)$. Private secondary school data in Goldin include students in the preparatory departments of colleges and universities. 1948-1997, Digest of Education Statistics 1997 (1997), table 99.

<CG.A.11.6>, 1870-1997, Digest of Education Statistics 1997 (1997), table 99, with the exceptions of 1910 and 1920 for which the data implicit in Historical Statistics (1975) series H 598 and H 599 are used. Data for the intercensal years from 1911 to 1929 are estimated using an exponential growth rate extrapolation procedure.

$<$ CG.A.11.7> is the ratio of <CG.A.11.1> and <CG.A.11.6> multiplied by 100 .

High school graduates include graduates from public and nonpublic schools and exclude persons granted equivalency certificates, such as the General Education Development credential (see <CG.A.12>). Individuals of any age receiving a high school diploma are included. The offical Department (Office) of Education data on the number of graduates differ from those in the contemporaneous publications of the Office of Education particularly prior to the mid-1930s when the series were substantially revised. There appears to be no extant documentation of the rationale for the revisions, but see Claudia Goldin, "America's Graduation from High School: The Evolution and Spread of Secondary Schooling in the Twentieth Century," Journal of Economic History 58 (June 1998): 345-74, for a method that produces estimates close to those of the Department (Office) of Education which are given here. The inference from Goldin's work is that the Department (Office) of Education revisions applied reasonable estimates of undercounts to schools reporting and added to the private school figures students exiting from the preparatory departments of colleges and universities.

Footnotes:

11: Graduates do not include those receiving General Education Development (GED) credentials. For data on GED credentials issues, see $\langle$ CG.A.12>.

12: The sum of males and females may not always equal the total because of rounding error and because different sources are used for the series after 1989. Graduation data by sex are not given in the Digest after 1983.

13: The sum of public and private may not always equal the total because of rounding error.

14: The division by the number of 17-year olds is customary and should not be taken to imply that graduates were 17-years old. The estimation of the number of 17-year olds and the fact that not all graduates were 17-years old, creates some problems for the year-to-year movement in the overall series. See notes 5 and 6.

15: The number of 17-year olds for 1910 and 1920 given in the U.S. population census is considerably lower than the number of 16 and 18-year olds. The data implicit in Historical Statistics (1975) series H 598 and H 599 appear to have averaged the numbers in the larger group of older teens. Those are the numbers given here.

16: The change in graduation rate from 1963 to 1966 appears to be a function of the number of 17-year olds rather than the number of graduates. The increase from 1964 to 1965 in the number of 17-year olds is the largest on record in the United States.

17: Data for 1984 to1991 are estimates based on data published by the Bureau of Labor Statistics. 
<CG.A.15> School enrollment of 5- to 19-year-olds per 100 persons, by sex and race: 1850 to 1994

\begin{tabular}{|c|c|c|c|c|c|c|c|c|c|}
\hline \multirow[b]{2}{*}{ Year } & \multicolumn{3}{|c|}{ Both sexes } & \multicolumn{3}{|c|}{ Male } & \multicolumn{3}{|c|}{ Female } \\
\hline & Total & White & \begin{tabular}{|c|} 
African- \\
American \\
and other \\
races $^{1}$ \\
\end{tabular} & Total & White & \begin{tabular}{|c|} 
African- \\
American \\
and other \\
races $^{1}$ \\
\end{tabular} & Total & White & \begin{tabular}{|c|} 
African- \\
American \\
and other \\
races $^{1}$ \\
\end{tabular} \\
\hline Units & $\%$ & $\%$ & $\%$ & $\%$ & $\%$ & $\%$ & $\%$ & $\%$ & $\%$ \\
\hline HS no. & H433 & H434 & H435 & H436 & H437 & H438 & H439 & $\mathrm{H} 440$ & H441 \\
\hline col. no. & (1) & (2) & (3) & (4) & (5) & (6) & (7) & (8) & (9) \\
\hline 1850 & 47.2 & 56.2 & 1.8 & 49.6 & 59.0 & 2.0 & 44.8 & 53.3 & 1.8 \\
\hline 1860 & 50.6 & 59.6 & 1.9 & 52.6 & 62.0 & 1.9 & 48.5 & 57.2 & 1.8 \\
\hline 1870 & 48.4 & 54.4 & 9.9 & 49.8 & 56.0 & 9.6 & 46.9 & 52.7 & 10.0 \\
\hline 1880 & 57.8 & 62.0 & 33.8 & 59.2 & 63.5 & 34.1 & 56.5 & 60.5 & 33.5 \\
\hline 1890 & 54.3 & 57.9 & 32.9 & 54.7 & 58.5 & 31.8 & 53.8 & 57.2 & 33.9 \\
\hline $1900^{2}$ & 50.5 & 53.6 & 31.1 & 50.1 & 53.4 & 29.4 & 50.9 & 53.9 & 32.8 \\
\hline $1910^{2}$ & 59.2 & 61.3 & 44.8 & 59.1 & 61.4 & 43.1 & 59.4 & 61.3 & 46.6 \\
\hline $1920^{2}$ & 64.3 & 65.7 & 53.5 & 64.1 & 65.6 & 52.5 & 64.5 & 65.8 & 54.5 \\
\hline $1930^{2,3}$ & 69.9 & 71.2 & 60.3 & 70.2 & 71.4 & 59.7 & 69.7 & 70.9 & 60.8 \\
\hline 1940 & 74.8 & 75.6 & 68.4 & 74.9 & 75.9 & 67.5 & 74.7 & 75.4 & 69.2 \\
\hline 1950 & 78.7 & 79.3 & 74.8 & 79.1 & 79.7 & 74.7 & 78.4 & 78.9 & 74.9 \\
\hline 1954 & 86.2 & 87.0 & 80.8 & 87.5 & 88.4 & 80.9 & 84.8 & 85.4 & 80.7 \\
\hline 1955 & 86.5 & 87.0 & 82.9 & 88.4 & 88.9 & 84.6 & 84.5 & 85.0 & 81.2 \\
\hline 1956 & 87.2 & 87.8 & 83.6 & 88.6 & 89.4 & 83.6 & 85.8 & 86.1 & 83.5 \\
\hline 1957 & 87.8 & 88.2 & 85.3 & 89.4 & 90.0 & 85.6 & 86.2 & 86.4 & 85.0 \\
\hline 1958 & 88.4 & 88.9 & 85.1 & 90.1 & 90.5 & 87.2 & 86.7 & 87.2 & 82.9 \\
\hline 1959 & 88.5 & 88.8 & 85.9 & 89.7 & 90.2 & 86.8 & 87.1 & 87.5 & 85.0 \\
\hline $1960^{*}$ & 88.6 & 89.0 & 86.1 & 90.0 & 90.6 & 86.6 & 87.1 & 87.3 & 85.7 \\
\hline 1961 & 88.5 & 88.9 & 86.3 & 90.2 & 90.5 & 87.7 & 86.9 & 87.2 & 84.9 \\
\hline 1962 & 89.1 & 89.6 & 86.3 & 90.8 & 91.3 & 87.6 & 87.4 & 87.8 & 85.0 \\
\hline 1963 & 89.6 & 89.8 & 88.0 & 91.1 & 91.5 & 88.7 & 88.0 & 88.1 & 87.3 \\
\hline 1964 & 89.6 & 89.8 & 88.4 & 91.1 & 91.4 & 89.2 & 88.1 & 88.2 & 87.6 \\
\hline 1965 & 89.6 & 89.8 & 88.5 & 91.0 & 91.2 & 89.8 & 88.3 & 88.5 & 87.2 \\
\hline 1966 & 89.7 & 89.9 & 88.5 & 91.2 & 91.5 & 89.9 & 88.2 & 88.4 & 87.2 \\
\hline 1967 & 90.5 & 90.8 & 88.6 & 91.9 & 92.2 & 89.8 & 89.0 & 89.3 & 87.4 \\
\hline 1968 & 90.8 & 91.0 & 89.4 & 92.2 & 92.5 & 90.5 & 89.3 & 89.5 & 88.4 \\
\hline 1969 & 90.9 & 91.1 & 89.5 & 92.1 & 92.5 & 90.0 & 89.5 & 89.7 & 88.9 \\
\hline 1970 & 90.6 & 90.8 & 89.4 & 91.6 & 91.9 & 89.6 & 89.6 & 89.7 & 89.1 \\
\hline 1971 & 90.9 & 90.9 & 90.8 & 91.9 & 92.0 & 91.3 & 89.9 & 89.8 & 90.3 \\
\hline 1972 & 90.0 & 90.0 & 90.1 & 91.0 & 91.0 & 90.9 & 89.0 & 89.0 & 89.3 \\
\hline 1973 & 89.3 & 89.4 & 88.9 & 90.3 & 90.4 & 90.1 & 88.2 & 88.3 & 87.7 \\
\hline 1974 & 89.4 & 89.2 & 90.1 & 90.1 & 89.9 & 90.9 & 88.6 & 88.5 & 89.3 \\
\hline 1975 & 89.9 & 89.8 & 90.4 & 90.7 & 90.6 & 91.1 & 89.1 & 89.0 & 89.6 \\
\hline 1976 & 89.6 & 89.4 & 90.8 & 90.4 & 90.1 & 91.9 & 88.9 & 88.7 & 89.6 \\
\hline 1977 & 89.6 & 89.3 & 91.1 & 90.3 & 89.9 & 91.9 & 89.0 & 88.8 & 90.2 \\
\hline 1978 & 89.2 & 89.0 & 90.6 & 89.8 & 89.5 & 91.6 & 88.6 & 88.4 & 89.7 \\
\hline 1979 & 89.0 & 88.8 & 90.2 & 89.7 & 89.4 & 91.5 & 88.3 & 88.1 & 88.8 \\
\hline 1980 & 89.1 & 88.9 & 90.4 & 89.5 & 89.3 & 90.4 & 88.8 & 88.4 & 90.4 \\
\hline 1981 & 89.6 & 89.4 & 90.5 & 90.0 & 89.8 & 91.4 & 89.2 & 89.1 & 89.7 \\
\hline
\end{tabular}


$<$ CG.A.15> continued

\begin{tabular}{|l|c|c|c|c|c|c|c|c|c|}
\hline \multirow{2}{*}{ Year } & \multicolumn{3}{|c|}{ Both sexes } & \multicolumn{3}{c|}{ Male } & \multicolumn{3}{c|}{ Female } \\
\cline { 2 - 10 } & Total & White & $\begin{array}{c}\text { African- } \\
\text { American } \\
\text { and other } \\
\text { races }\end{array}$ & Total & White & $\begin{array}{c}\text { African- } \\
\text { American } \\
\text { and other } \\
\text { races }^{1}\end{array}$ & Total & White & $\begin{array}{c}\text { African- } \\
\text { American } \\
\text { and other } \\
\text { races }^{1}\end{array}$ \\
\hline Units & $\%$ & $\%$ & $\%$ & $\%$ & $\%$ & $\%$ & $\%$ & $\%$ & $\%$ \\
\hline HS no. & $H 433$ & $H 434$ & $H 435$ & $H 436$ & $H 437$ & $H 438$ & $H 439$ & $H 440$ & $H 441$ \\
\hline col. no. & $(1)$ & $(2)$ & $(3)$ & $(4)$ & $(5)$ & $(6)$ & $(7)$ & $(8)$ & $(9)$ \\
\hline 1982 & 89.6 & 89.5 & 90.0 & 90.0 & 89.9 & 90.6 & 89.1 & 89.1 & 89.4 \\
\hline 1983 & 90.3 & 90.3 & 90.3 & 90.4 & 90.3 & 90.8 & 90.2 & 90.2 & 89.8 \\
\hline 1984 & 90.3 & 90.3 & 90.2 & 90.7 & 90.6 & 90.9 & 89.9 & 90.0 & 89.5 \\
\hline 1985 & 91.0 & 91.1 & 90.7 & 91.2 & 91.2 & 91.4 & 90.7 & 90.9 & 89.9 \\
\hline 1986 & 91.4 & 91.3 & 91.6 & 92.0 & 91.8 & 92.6 & 90.8 & 90.8 & 90.7 \\
\hline 1987 & 91.7 & 91.5 & 92.3 & 92.4 & 92.2 & 93.2 & 90.9 & 90.8 & 91.4 \\
\hline 1988 & 91.8 & 91.7 & 92.2 & 92.1 & 91.6 & 94.5 & 91.5 & 91.4 & 91.9 \\
\hline 1989 & 91.8 & 91.7 & 92.1 & 92.1 & 92.1 & 92.2 & 91.5 & 91.3 & 92.0 \\
\hline 1990 & 92.6 & 92.5 & 92.8 & 92.9 & 92.6 & 93.8 & 92.2 & 92.3 & 91.8 \\
\hline 1991 & 93.1 & 93.1 & 93.2 & 93.4 & 93.1 & 94.2 & 92.8 & 93.0 & 92.2 \\
\hline 1992 & 93.5 & 93.5 & 93.4 & 93.9 & 93.7 & 94.8 & 93.1 & 93.4 & 92.0 \\
\hline 1993 & 93.6 & 93.6 & 93.3 & 93.8 & 93.6 & 94.5 & 93.3 & 93.5 & 92.4 \\
\hline 1994 & 93.5 & 93.5 & 93.6 & 93.6 & 93.6 & 93.6 & 93.4 & 93.3 & 93.5 \\
\hline
\end{tabular}

Sources: <CG.A.15.1> to <CG.A.15.9>, 1850 to 1991, U.S. Department of Education, 120 Years of American Education: A Statistical Portrait (Washington, D.C.: U.S. G.P.O., 1993), table 2. The underlying sources are: U.S. Bureau of the Census, Fifteenth Census (1940) Reports, Population, vol. II; U.S. Bureau of the Census, Census of Population: 1950, vol. II, part 1; U.S. Bureau of the Census, Census of Population: 1960, PC(1)-1D; and Current Population Reports, series P-20, "School Enrollment: Social and Economic Characteristics of Students," various years, and Current Population Survey, survey data files. 1991 to 1994, Current Populations Reports, series P-20, nos. 474, 479, and 487.

Data for 1850 through 1950 are based on April 1 counts of population. Data for 1954 to 1994 are based on October counts.

For decennial census years, the statistics refer to the total population within the specified age group; figures from the Current Population Survey (CPS) refer to the civilian noninstitutional population. Persons not covered in the CPS (Armed Forces and institutional population) are known to have low enrollment rates.

In the U.S. population census for 1940 and 1950, and in the CPS, 1954 to 1991, enrollment was defined as enrollment in "regular" schools only - that is, schools where enrollment may lead toward an elementary or high school diploma, or to a college, university, or professional school degree. Such schools included public and private nursery schools, kindergartens, elementary and secondary schools, colleges, universities, and professional schools. Enrollment could be either full-time or part-time, day or night.

If a person was receiving regular instruction at home from a tutor and if the instruction was considered comparable to that of a regular school or college, the person was counted as enrolled. Enrollment in a correspondence course was counted only if the person received credit in the regular school system. Enrollments in business and trade schools at the postsecondary level were excluded if the coursework did not lead to a degree. 
Children enrolled in kindergarten were included in the "regular" school enrollment figures in the Current Population Survey beginning in 1950; children enrolled in nursery school were included beginning in 1967. Children enrolled in kindergarten were not included in the "regular" school enrollment figures in the 1950 U.S. population census, however, they have been included here to make the data comparable with earlier years and with current practice. In censuses prior to 1950, no attempt was made to exclude children in kindergarten so that statistics for those years include various proportions attending kindergarten. Also, in censuses prior to 1940, the data were not restricted as to type of school or college the person was attending.

In addition to differences in definition of school enrollment and in population coverage, the enrollment data for different years may differ because of variations in the dates when the questions were asked and the time periods to which enrollment referred. Data from the Current Population Survey were obtained in October and refer to enrollment in the current school term. In 1940, 1950, and 1960, the censuses were taken as of April 1, but enrollment related to any time after March 1 in 1940 and any time after February 1 in 1950 and 1960. The corresponding questions in the censuses from 1850 to 1930 applied to a somewhat longer period: in 1850 to 1900 , to the 12 months preceding the census date; and in 1910, 1920, and 1930, to the period between the preceding September 1 and the census date (April 15 in 1910, January 1 in 1920, and April 1 in 1930).

Information on school enrollment is also collected and published by the Department of Education. These data are obtained from reports of school surveys and censuses. They are, however, only roughly comparable with data collected by the Bureau of the Census from households, because of differences in definitions, time references, population coverage, and enumeration methods. It is almost always the case that the enrollment percentages in the household survey data exceed those in the school surveys for individuals of roughly comparable ages.

\section{Footnotes:}

11: For 1971 to 1994 , the category "African-American and other races" is calculated by subtracting whites from the total.

12: Enrollment rates are for 5- to 20-year-olds.

13: Revised to include Mexicans as white persons. 
<CG.A.16> Unionization of teachers and instructional staff: NEA and AFT membership and union density measures, 1960 to 1997

\begin{tabular}{|c|c|c|c|c|c|c|c|c|}
\hline \multirow[t]{2}{*}{ Year } & \multicolumn{2}{|c|}{$\begin{array}{c}\text { National Educational } \\
\text { Association (NEA) }\end{array}$} & \multirow{2}{*}{$\begin{array}{c}\text { American } \\
\text { Federation of } \\
\text { Teachers } \\
\text { (AFT), total } \\
\text { membership }\end{array}$} & \multirow{2}{*}{\begin{tabular}{|c|} 
(NEA, K-12 and \\
AFT membership)/ \\
all public school \\
instructional staff
\end{tabular}} & \multicolumn{2}{|c|}{ Fraction union members } & \multicolumn{2}{|c|}{$\begin{array}{c}\text { Fraction covered by collective } \\
\text { bargaining agreements }\end{array}$} \\
\hline & $\begin{array}{c}\text { Total } \\
\text { membership }\end{array}$ & $\begin{array}{l}\text { K-12 instructional } \\
\text { staff membership }\end{array}$ & & & $\begin{array}{c}\text { Elementary } \\
\text { school teachers }\end{array}$ & \begin{tabular}{|c|} 
Secondary \\
school teachers
\end{tabular} & $\begin{array}{c}\text { Elementary } \\
\text { school teachers }\end{array}$ & $\begin{array}{l}\text { Secondary } \\
\text { school } \\
\text { teachers }\end{array}$ \\
\hline Units & number & number & thousands & fraction & fraction & fraction & fraction & fraction \\
\hline HS no. & new & new & new & new & new & new & new & new \\
\hline col. no. & (1) & (2) & (3) & (4) & (5) & (6) & (7) & (8) \\
\hline 1960 & 713,994 & --- & 56 & --- & --- & --- & --- & --- \\
\hline 1961 & 765,616 & ---- & (NA) & ---- & ---- & ---- & ---- & ---- \\
\hline 1962 & 812,497 & ---- & 58 & --- & --- & ---- & ---- & ---- \\
\hline 1963 & 859,505 & ---- & (NA) & ---- & ---- & ---- & ---- & ---- \\
\hline 1964 & 903,384 & ---- & (NA) & ---- & ---- & ---- & ---- & ---- \\
\hline 1965 & 943,581 & ---- & (NA) & ---- & ---- & ---- & ---- & ---- \\
\hline 1966 & 986,113 & ---- & (NA) & ---- & ---- & ---- & ---- & ---- \\
\hline 1967 & $1,028,456$ & ---- & (NA) & ---- & ---- & ---- & ---- & ---- \\
\hline 1968 & $1,081,660$ & ---- & (NA) & ---- & ---- & ---- & ---- & ---- \\
\hline 1969 & $1,014,275$ & ---- & (NA) & $-\cdots-$ & ---- & ---- & ---- & ---- \\
\hline 1970 & $1,100,155$ & ---- & 188 & ---- & ---- & ---- & ---- & ---- \\
\hline 1971 & $1,103,485$ & ---- & 197 & ---- & ---- & ---- & ---- & ---- \\
\hline 1972 & $1,166,203$ & ---- & 225 & ---- & ---- & ---- & ---- & ---- \\
\hline 1973 & $1,377,998$ & ---- & 204 & ---- & ---- & ---- & ---- & ---- \\
\hline 1974 & $1,467,186$ & ---- & 326 & ---- & 0.264 & 0.286 & ---- & ---- \\
\hline 1975 & $1,684,909$ & ---- & 380 & ---- & 0.288 & 0.306 & ---- & ---- \\
\hline 1976 & $1,886,532$ & ---- & 323 & ---- & 0.344 & 0.379 & ---- & ---- \\
\hline 1977 & $1,679,689$ & ---- & 347 & ---- & 0.416 & 0.455 & ---- & ---- \\
\hline 1978 & $1,696,469$ & $\begin{array}{ll}--- \\
\end{array}$ & 390 & $\begin{array}{ll}--- \\
\end{array}$ & 0.505 & 0.558 & $\begin{array}{ll}--- \\
\end{array}$ & $\begin{array}{ll}--- \\
\end{array}$ \\
\hline 1979 & $1,709,673$ & ---- & 452 & ---- & 0.528 & 0.579 & ---- & ---- \\
\hline 1980 & $1,680,566$ & ---- & 393 & ---- & 0.544 & 0.599 & ---- & ---- \\
\hline 1981 & $1,659,459$ & $\begin{array}{ll}--- \\
\end{array}$ & 515 & $\begin{array}{ll}--- \\
\end{array}$ & (NA) & (NA) & $\begin{array}{ll}--- \\
\end{array}$ & $\begin{array}{ll}--- \\
\end{array}$ \\
\hline 1982 & $1,644,459$ & ---- & 459 & ---- & (NA) & (NA) & ---- & ---- \\
\hline \begin{tabular}{|l|}
1983 \\
\end{tabular} & $1,633,205$ & $1,496,930$ & 457 & $\begin{array}{l}--- \\
\end{array}$ & 0.577 & 0.574 & 0.691 & 0.694 \\
\hline 1984 & $1,654,825$ & $1,541,070$ & (NA) & ---- & 0.568 & 0.575 & 0.672 & 0.689 \\
\hline 1985 & $1,688,057$ & $1,496,993$ & 470 & 0.556 & 0.566 & 0.580 & 0.667 & 0.676 \\
\hline
\end{tabular}


<CG.A.16> continued

\begin{tabular}{|c|c|c|c|c|c|c|c|c|}
\hline \multirow[t]{2}{*}{ Year } & \multicolumn{2}{|c|}{$\begin{array}{l}\text { National Educational } \\
\text { Association (NEA) }\end{array}$} & \multirow{2}{*}{$\begin{array}{c}\text { American } \\
\text { Federation of } \\
\text { Teachers } \\
\text { (AFT), total } \\
\text { membership }\end{array}$} & \multirow{2}{*}{\begin{tabular}{|c|} 
(NEA, K-12 and \\
AFT membership)// \\
all public school \\
instructional staff
\end{tabular}} & \multicolumn{2}{|c|}{ Fraction union members } & \multicolumn{2}{|c|}{$\begin{array}{c}\text { Fraction covered by collective } \\
\text { bargaining agreements }\end{array}$} \\
\hline & $\begin{array}{c}\text { Total } \\
\text { membership }\end{array}$ & $\begin{array}{l}\text { K-12 instructional } \\
\text { staff membership }\end{array}$ & & & $\begin{array}{c}\text { Elementary } \\
\text { school teachers }\end{array}$ & $\begin{array}{c}\text { Secondary } \\
\text { school teachers }\end{array}$ & $\begin{array}{c}\text { Elementary } \\
\text { school teachers }\end{array}$ & $\begin{array}{l}\text { Secondary } \\
\text { school } \\
\text { teachers }\end{array}$ \\
\hline Units & number & number & thousands & fraction & fraction & fraction & fraction & fraction \\
\hline HS no. & new & new & new & new & new & new & new & new \\
\hline col. no. & (1) & (2) & (3) & (4) & (5) & (6) & (7) & (8) \\
\hline 1986 & $1,799,144$ & (NA) & (NA) & (NA) & 0.546 & 0.574 & 0.647 & 0.684 \\
\hline \begin{tabular}{|l|}
1987 \\
\end{tabular} & $1,828,649$ & $1,552,236$ & 494 & 0.550 & 0.578 & 0.584 & 0.667 & 0.675 \\
\hline 1988 & $1,919,773$ & $1,579,689$ & (NA) & 0.552 & 0.564 & 0.603 & 0.661 & 0.693 \\
\hline 1989 & $1,992,917$ & $1,765,862$ & 544 & 0.602 & 0.554 & 0.588 & 0.658 & 0.673 \\
\hline 1990 & $2,057,286$ & $1,814,669$ & (NA) & 0.608 & 0.560 & 0.556 & 0.656 & 0.666 \\
\hline 1991 & $2,109,866$ & $1,859,480$ & 459 & 0.609 & 0.558 & 0.569 & 0.636 & 0.661 \\
\hline \begin{tabular}{|l|}
1992 \\
\end{tabular} & $2,143,170$ & $1,884,001$ & (NA) & 0.607 & 0.540 & 0.571 & 0.622 & 0.667 \\
\hline 1993 & $2,171,682$ & $1,906,694$ & 574 & 0.607 & 0.582 & 0.571 & 0.660 & 0.659 \\
\hline 1994 & $2,205,661$ & $1,935,642$ & (NA) & 0.603 & 0.570 & 0.586 & 0.644 & 0.665 \\
\hline 1995 & $2,249,703$ & (NA) & 613 & (NA) & 0.559 & 0.584 & 0.634 & 0.652 \\
\hline 1996 & $2,279,101$ & $1,998,016$ & (NA) & (NA) & 0.556 & 0.578 & 0.632 & 0.648 \\
\hline 1997 & $2,323,339$ & $2,034,087$ & $(F)$ & (NA) & 0.570 & 0.561 & 0.645 & 0.634 \\
\hline
\end{tabular}


Sources:

<CG.A.16.1> and <CG.A.16.2>, 1960 to 1997, NEA Handbook, [year] (Washington, D.C.: National Education Association), annual issues. <CG.A.16.3>, 1960 to 1983, Leo Troy and Neil Sheflin, U.S. Union Sourcebook: Membership, Finances, Structure, Directory (West Orange, NJ: Industrial Relations Data and Information Services, 1985); 1984 to 1995, Statistical Abstract of the United States [year] (Washington, D.C.: U.S. G.P.O.), various issues. <CG.A.16.4>, is equal to <CG.A.16.2> plus $<$ CG.A.16.3> divided by <CG.A.7.1>. <CG.A.16.5> and <CG.A.16.6>, 1973 to 1980, Edward C. Kokkelenberg and Donna R. Sockell, "Union Membership in the United States, 1973-1981," Industrial and Labor Relations Review 28 (July 1985), p. 507. <CG.A.16.5> to <CG.A.16.8>, 1983 to 1997, Barry T. Hirsch and David A. Macpherson, Union Membership and Earnings Data Book: Compilations from the Current Population Survey (Washington, D.C.: Bureau of National Affairs), annual issues. Underlying source is Current Population Survey (CPS) Outgoing Rotation Group (ORG) Earnings Files, 1983 to 1997.

The National Education Association (NEA) has been in existence since 1857, when it was the National Teachers' Association, as a professional association of teachers and other instructional staff. As various localities and states granted formal bargaining rights to their public-sector workers in the early 1950s and states passed legislation for school bargaining (beginning with Wisconsin in 1959), local NEA chapters became the bargaining agents for teachers. Although some states still do not allow public-sector employees to bargain collectively, most states passed enabling legislation in the 1960s and 1970s (fortyone states had such legislation in 1975). The American Federation of Teachers (AFT), a union affiliated with the AFL-CIO since its founding in 1916, also has local chapters that are bargaining agents for teachers.

NEA membership data in <CG.A.16.1> include dues-paying members who are K-12 and highereducation teachers (including substitute teachers), other instructional staff, non-instructional staff, NEA staff, and post-secondary school students in training for educational positions. Members can be active, retired, or lifetime. NEA membership data in $\langle$ CG.A.16.2> include only K-12 teachers and other instructional staff, active and lifetime members. Thus $<$ CG.A.16.1 $>$ can exceed the total number of public-sector, K-12 active instructional staff. The NEA and AFT data do not, according to Troy and Sheflin, include Canadian members or private school teachers and instructional staff, but there may be a trivial number of private higher education teachers in the NEA membership data.

The CPS data include all wage and salary workers who listed their occupation as teacher (elementary or secondary school).

By "union density" is meant the fraction of a group (here an occupation) who belong to a union or are represented in a collective bargaining agreement by a union. 
<CG.A.17> Public and private secondary school graduation rates by census division and race: 1910 to 1962

\begin{tabular}{|c|c|c|c|c|c|c|c|c|c|c|c|c|}
\hline \multirow{3}{*}{$\begin{array}{l}\text { School } \\
\text { year } \\
\text { ending }\end{array}$} & \multicolumn{12}{|c|}{ Public and private secondary school graduation rate } \\
\hline & \multirow{2}{*}{\begin{tabular}{|c|} 
New \\
England
\end{tabular}} & \multirow{2}{*}{$\begin{array}{l}\text { Middle } \\
\text { Atlantic }\end{array}$} & \multicolumn{2}{|c|}{ South Atlantic } & \multicolumn{2}{|c|}{ East South Central } & \multicolumn{2}{|c|}{ West South Central } & \multirow{2}{*}{$\begin{array}{c}\text { East North } \\
\text { Central }\end{array}$} & \multirow{2}{*}{$\begin{array}{c}\text { West North } \\
\text { Central }\end{array}$} & \multirow[t]{2}{*}{ Mountain } & \multirow[t]{2}{*}{ Pacific } \\
\hline & & & All & Whites $^{2}$ & All & Whites $^{2}$ & All & Whites $^{2}$ & & & & \\
\hline Units & fraction & fraction & fraction & fraction & fraction & fraction & fraction & fraction & fraction & fraction & fraction & fraction \\
\hline HS no. & new & new & new & new & new & new & new & new & new & new & new & new \\
\hline col. no. & (1) & (2) & (3) & (4) & (5) & (6) & (7) & (8) & (9) & (10) & (11) & (12) \\
\hline 1910 & 0.155 & 0.080 & 0.041 & ---- & 0.038 & ---- & 0.043 & ---- & 0.125 & 0.106 & 0.088 & 0.117 \\
\hline 1911 & 0.165 & 0.088 & 0.046 & ---- & 0.042 & ---- & 0.051 & ---- & 0.130 & 0.111 & 0.102 & 0.132 \\
\hline 1913 & 0.187 & 0.102 & 0.059 & $-\cdots--$ & 0.056 & ---- & 0.062 & ---- & 0.153 & 0.136 & 0.130 & 0.171 \\
\hline 1914 & 0.201 & 0.110 & 0.065 & --- & 0.062 & ---- & 0.068 & --- & 0.162 & 0.146 & 0.129 & 0.192 \\
\hline 1916 & 0.228 & 0.129 & 0.075 & ---- & 0.074 & ---- & 0.079 & ---- & 0.183 & 0.174 & 0.164 & 0.229 \\
\hline 1918 & 0.246 & 0.142 & 0.085 & --- & 0.084 & $-\cdots$ & 0.110 & --- & 0.215 & 0.199 & 0.185 & 0.248 \\
\hline 1920 & 0.253 & 0.139 & 0.086 & --- & 0.086 & --- & 0.120 & --- & 0.209 & 0.205 & 0.198 & 0.273 \\
\hline 1922 & 0.272 & 0.165 & 0.105 & ---- & 0.103 & --- & 0.130 & ---- & 0.250 & 0.246 & 0.239 & 0.309 \\
\hline 1924 & 0.309 & 0.197 & 0.135 & ---- & 0.133 & ---- & 0.166 & ---- & 0.298 & 0.304 & 0.293 & 0.359 \\
\hline 1926 & 0.337 & 0.217 & 0.156 & --- & 0.139 & --- & 0.184 & --- & 0.311 & 0.387 & 0.312 & 0.394 \\
\hline 1928 & 0.359 & 0.223 & 0.171 & --- & 0.162 & --- & 0.198 & ---- & 0.334 & 0.394 & 0.353 & 0.432 \\
\hline 1930 & 0.394 & 0.254 & 0.192 & 0.242 & 0.170 & 0.214 & 0.225 & 0.253 & 0.360 & 0.410 & 0.380 & 0.447 \\
\hline 1932 & 0.478 & 0.316 & 0.225 & 0.288 & 0.184 & 0.233 & 0.276 & 0.314 & 0.430 & 0.476 & 0.454 & 0.551 \\
\hline 1934 & 0.512 & 0.389 & 0.250 & 0.297 & 0.210 & 0.248 & 0.295 & 0.327 & 0.494 & 0.504 & 0.481 & 0.567 \\
\hline 1936 & 0.586 & 0.474 & 0.307 & 0.378 & 0.245 & 0.299 & 0.343 & 0.385 & 0.530 & 0.545 & 0.532 & 0.625 \\
\hline 1938 & 0.599 & 0.516 & 0.353 & 0.432 & 0.260 & 0.310 & 0.381 & 0.423 & 0.543 & 0.578 & 0.557 & 0.678 \\
\hline 1940 & 0.602 & 0.543 & 0.377 & 0.444 & 0.303 & 0.356 & 0.427 & 0.473 & 0.572 & 0.615 & 0.576 & 0.711 \\
\hline $1942^{1}$ & 0.616 & 0.579 & 0.409 & 0.484 & 0.309 & 0.364 & 0.463 & 0.518 & 0.618 & 0.623 & 0.589 & 0.666 \\
\hline $1944^{1}$ & 0.454 & 0.514 & 0.355 & 0.411 & 0.260 & 0.302 & 0.376 & 0.420 & 0.541 & 0.543 & 0.476 & 0.532 \\
\hline $1946^{1}$ & 0.563 & 0.553 & 0.310 & 0.349 & 0.292 & 0.339 & 0.383 & 0.425 & 0.579 & 0.582 & 0.523 & 0.597 \\
\hline $1948^{1}$ & 0.625 & 0.622 & 0.369 & 0.410 & 0.347 & 0.397 & 0.450 & 0.501 & 0.637 & 0.636 & 0.580 & 0.653 \\
\hline $1950^{1}$ & 0.665 & 0.631 & 0.408 & 0.441 & 0.388 & 0.441 & 0.450 & 0.496 & 0.638 & 0.64 & 0.573 & 0.638 \\
\hline 1952 & 0.591 & 0.567 & 0.387 & 0.420 & 0.379 & 0.421 & 0.443 & 0.481 & 0.584 & 0.623 & 0.539 & 0.557 \\
\hline 1954 & 0.610 & 0.561 & 0.433 & 0.464 & 0.455 & 0.448 & 0.515 & 0.501 & 0.625 & 0.668 & 0.588 & 0.599 \\
\hline $1958^{1}$ & 0.622 & 0.592 & 0.475 & (NA) & 0.478 & (NA) & 0.531 & (NA) & 0.623 & 0.68 & 0.595 & 0.624 \\
\hline 1962 & 0.682 & 0.652 & 0.542 & (NA) & 0.523 & (NA) & 0.579 & (NA) & 0.656 & 0.702 & 0.651 & 0.716 \\
\hline
\end{tabular}


Sources: <CG.A.17.1> to <CG.A.17.12>, 1910 to 1962, U.S. Office (Department) of Education, Biennial Surveys of Education of the United States, various years; U.S. Department of Health, Education, and Welfare, Statistics of State School Systems and Statistics of Non-Public Secondary Schools, various years; National Catholic Welfare Conference, Summary of Catholic Education, various years. See Claudia Goldin, "America's Graduation from High School: The Evolution and Spread of Secondary Schooling in the Twentieth Century," Journal of Economic History 58 (June 1998): 345-74, and "Appendix to How America Graduated from High School," National Bureau of Economic Research Historical Working Paper no. 57 (June 1994), although some of the numbers have been reestimated. The numbers of 17-year olds (or half the number of 17- and 18-year olds) by state are from the decennial U.S. population censuses (1910 to 1970) and are interpolated between census years using a constant growth rate procedure.

The graduation rate is the number of secondary school graduates in a given year divided by the number of 17-year olds in that year. Thus, the data represent the contemporaneous graduation rate. It does not matter that secondary school graduates can be more (or less) than seventeen years old. The age of seventeen is chosen for convenience and because there is generally less understatement for males at that age than after. Graduates can be from public schools (junior highs, senior highs, regular high schools, and so on), private schools (secular and denominational), or the preparatory departments of colleges and universities. The criterion for graduation may depend on state regulations. See $\langle$ CG.A.11 $\rangle$ for the national graduation rates. The data underlying the estimates for the states (aggregated here to the census division level), sum to approximately the aggregate data for the nation by year. See references under sources for details. Because of the lack of private school statistics, these data cannot easily be extended beyond 1962.

Census divisions are standard; see, for example, U.S. Bureau of the Census, Historical Statistics of the United States (Washington, D.C.: U.S. G.P.O., 1975), p. 5.

Footnotes:

11: Extrapolated on the basis of the public secondary school graduate rate because the number of private school graduates cannot be estimated reliably for 1942 to 1950 and for 1958.

12: Derived from the total number of graduates minus those from non-white segregated schools. 